University of Louisville

ThinkIR: The University of Louisville's Institutional Repository

$5-2020$

\title{
A forgotten shade of blue: support for the union and the constitutional republic in southeastern Kentucky during the civil war era.
}

Howard Muncy

University of Louisville

Follow this and additional works at: https://ir.library.louisville.edu/etd

Part of the Appalachian Studies Commons, Military History Commons, Political History Commons, and the United States History Commons

\section{Recommended Citation}

Muncy, Howard, "A forgotten shade of blue: support for the union and the constitutional republic in southeastern Kentucky during the civil war era." (2020). Electronic Theses and Dissertations. Paper 3456. https://doi.org/10.18297/etd/3456

This Master's Thesis is brought to you for free and open access by ThinkIR: The University of Louisville's Institutional Repository. It has been accepted for inclusion in Electronic Theses and Dissertations by an authorized administrator of ThinkIR: The University of Louisville's Institutional Repository. This title appears here courtesy of the author, who has retained all other copyrights. For more information, please contact thinkir@louisville.edu. 
A FORGOTTEN SHADE OF BLUE: SUPPORT FOR THE UNION AND THE CONSTITUTIONAL REPUBLIC IN SOUTHEASTERN KENTUCKY DURING THE CIVIL WAR ERA

\author{
By \\ Howard Muncy \\ B.A., Eastern Kentucky University, 2002 \\ M.A., Eastern Kentucky University, 2003
}

A Thesis Submitted to the Faculty of the College of Arts and Sciences of the University of Louisville in Partial Fulfillment of the Requirements for the Degree of

\author{
Master of Arts \\ in History
}

Department of History

University of Louisville

Louisville, Kentucky

May 2020 
Copyright 2020 by Howard Lucas Muncy

All rights reserved. 

A FORGOTTEN SHADE OF BLUE:

\title{
SUPPORT FOR THE UNION AND A CONSTITUTIONAL REPUBLIC IN
} SOUTHEASTERN KENTUCKY DURING THE CIVIL WAR ERA

\author{
By \\ Howard Lucas Muncy \\ B.A., Eastern Kentucky University, 2002 \\ M.A., Eastern Kentucky University, 2003
}

A Thesis Approved on

February 13, 2020

by the following Thesis Committee:

Thesis Advisor

Dr. Thomas C. Mackey

Dr. Daniel Krebs

Dr. Gary Gregg 


\section{DEDICATION}

I dedicate this thesis in memory of the

Union veterans from Kentucky. 


\section{ACKNOWLEDGEMENTS}

I would first like to thank my advisor Dr. Thomas Mackey and the entire thesis committee. Dr. Mackey's knowledge of the Civil War era and his patient direction were vital in the completion of this thesis. I also want to express gratitude to the James Madison Memorial Foundation for their 2016 Kentucky Senior Fellowship award. The Madison fellowship afforded me the opportunity to pursue this degree. Coursework with the history department at the University of Louisville and with the scholars at the summer institute at Georgetown University improved my writing and research skills during the completion of this master's program. The staffs from the Clay County Historical Society and the Jackson County Public Library’s Kentucky History Room offered helpful service in locating documents for this work. I would also like to thank James McPherson for invitation to his Princeton office where on separate occasions we discussed ideas about the Civil War. I want to acknowledge several groups, including the Gilder-Lehrman Institute of American History, the National Endowment of the Humanities, Liberty Fund, the Robert H. Smith Center for the Constitution at Montpelier, We the People, the Witherspoon Institute, and the McConnell Center. These institutions invested resources for my continuing education and connected me with scholars such as Richard Carwardine, James Klotter, Gordon Wood, Lucas Morel, and many others who were models of inspiration.

I must also express special appreciation to my family, friends, and colleagues who encouraged my work. Specifically, I want to thank my wife Kelly for her unwavering 
support every step of the way as I researched this important topic. My son Kaden took it all in stride. Finally, I want to honor my parents, William and Diane Muncy - their loving care and moral example have been a positive influence throughout my entire life. 


\title{
ABSTRACT \\ A FORGOTTEN SHADE OF BLUE: \\ SUPPORT FOR THE UNION AND A CONSTITUTIONAL REPUBLIC IN SOUTHEASTERN KENTUCKY DURING THE CIVIL WAR ERA
}

\author{
Howard L. Muncy
}

May 2020

This thesis analyzes Southeastern Kentucky's political and military support for the Union during the Civil War era. In the decades prior to the 1860 election, Kentucky developed deep social and economic ties with all sections of the country. After the secession winter that followed Abraham Lincoln's presidential election, the statewide population divided and pockets of significant Confederate sympathies emerged. Kentucky's southeastern counties aligned with the Union at the outbreak of the Civil War because of a strong national identity and the absence of a large slave population. As the war unfolded, Southeastern Kentuckians played an important role in the disruption of repeated Confederate invasions. Kentucky split again in the emancipationist phase of the war when guerilla warfare engulfed the slave state, but southeastern Kentuckians continued to support federal efforts with votes, enlistments, and service. In the final months of the conflict, and the years that followed, a core of Kentucky's southeastern counties did not drift toward the Confederacy's "lost cause," nor to the Democratic Party, as did much of the state. Instead, citizens from Southeastern Kentucky offered robust support for Union veterans and other Republican candidates who ran for both state and federal offices. This thesis illuminates the political activity and military service of citizens from Southeastern 
Kentucky during those turbulent years with attention to national events and other local populations proximate to the region of study. 
TABLE OF CONTENTS

PAGE

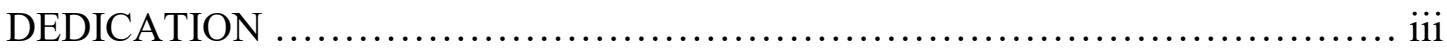

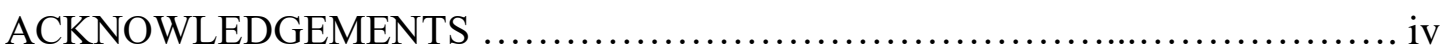

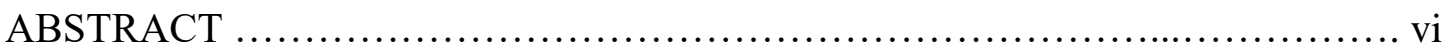

\section{INTRODUCTION}

"These Honored Dead". ...................................................... 1

\section{CHAPTER ONE}

"Gentlemen, I Too am a Kentuckian": Southeastern Kentucky in 1860

\section{CHAPTER TWO}

"The Union Sentiment Among the People Largely Predominates":

Southeastern Kentucky in 1861

\section{CHAPTER THREE}

"They are Having a Stampede in Kentucky, Look to It":

Civil War and Southeastern Kentucky 1862

\section{CHAPTER FOUR}

"As Soldiers Suffer to Anything, Even unto Death":

Kentucky in the Second Half of the Civil War

\section{CHAPTER FIVE}

"The Mystic Chords of Memory"

Voting Patterns, War Memory, and Attacks on the Mountaineer Image

\section{CHAPTER SIX}

"The Fiery Trial": A Civil War Histography

REFERENCES 


\section{INTRODUCTION \\ "THESE HONORED DEAD”}

When the full history of the war is written we shall realize more than we do our debt to the loyal people of the South. There [was] a larger proportion of descendants of revolution soldiery in Kentucky than any other state [who could] overflow their mountains and reinforce the nation.

- Theodore Roosevelt, $1897 .^{1}$

This master's thesis analyzes Union support from the Southeastern Kentucky population during the Civil War era. In 1861, when citizens across the South debated secession, Kentucky legislators rejected Governor Beriah Magoffin's Confederate maneuvering and pursued the impossible path of neutrality before eventually siding with the Union. As Kentucky Unionists and the state's General Assembly sought to preserve Kentucky's place in the nation-Confederate sympathies endangered the state's loyal position from within. Political and military leaders from the newly formed confederacy added to the internal threat of disunion and tried to reverse Kentucky's chosen course with a series of invasions and raids throughout the duration of the war. Historians have long sought to explain Kentucky's motives and loyalty during the period. To complicate Kentucky's Civil War legacy, the rise of a Confederate identity in the postwar period has done much to distort the state's important contributions to the Union victory. However,

\footnotetext{
${ }^{1}$ From Theodore Roosevelt's 1897 speech at Boston's Trinity Church as quoted in Anne Marshall's Creating a Confederate Kentucky: The Lost Cause and Civil War Memory in a Border State (Chapel Hill: University of North Carolina Press, 2010), 120.
} 
modern Civil War scholars have started to devote more historical attention to the significance of the Border States, including Kentucky. Much of the early historiography on the Appalachian regions of the United States identified a strong Union sentiment, but some modern works have pushed back against those conclusions with new claims that the unionism was overestimated. New studies that focus on smaller segments of the American population during the secession crisis, within smaller defined areas, advance a more complex understanding of the war. This thesis seeks to add to that secondary literature with focus on residents and soldiers in the southeastern region of Kentucky. Evidence suggests that the southeastern population of Kentucky formed a deep loyalty to the Union that, unlike many other areas in the state, increased as the war progressed. Events and records reveal a pattern of social, military, and political support from the area that proved vital to the Union and unique from the other portions of the Commonwealth.

To understand Southeastern Kentucky's Unionism at the outset of the Civil War, Chapter One of this study analyzes the election of 1860 . The chapter seeks to create a national context of Abraham Lincoln's election before the analysis turns to Kentucky's statewide outlook on the presidential race and then narrows down to examine results from a few counties in Southeastern Kentucky. Lincoln finished last in a four-way contest among the 1860 Kentucky electorate and the eventual sixteenth president registered less than one percent of the total state vote. A defined geographic area in Southeastern Kentucky offered Lincoln a significant portion, of his otherwise miniscule, political support in the Commonwealth. Chapter One also focuses on Kentucky's early abolitionist and antislavery movements. The chapter identifies a combination of 
religious, economic, and social forces that shaped opinions in the local area prior to the outbreak of war.

Chapter Two examines the formation of Kentucky Union military regiments during 1861. The need for military volunteers to protect Union interests interconnected a mixture of federal, state, and local officials. Politicians tapped influential rural citizens to recruit and organize Union troops in Southeastern Kentucky. Many of those prominent individuals possessed valuable experience with raising troops from America's previous wars and recruiting officers observed both patriotism and duty in their recruits. Chapter Two explores a variety of primary accounts and statistics to capture the sentiment of the region as the Civil War entered its first year. Actions in 1861 from Southeastern Kentucky's politicians in the General Assembly, and attitudes from area voters in statewide elections, reflect the same Unionist spirit observed in volunteers during the 1861 call to arms.

Chapter Three and Chapter Four present narrative histories of Kentucky's important Civil War events and features soldiers' experiences from Kentucky regiments that fought in the Western Theatre of Union military operations. Chapter Three focuses on the winter invasion of 1862 with attention to the repulse of Confederates at the Battle of Mill Springs. Following that Confederate failure, General Braxton Bragg and Kirby Smith's larger invasion in the summer campaign of 1862 reveals another example of the Confederates' difficulty with turning the state toward their cause. Chapter Four explores the second half of the Civil War and examines Kentucky's reactions to emancipationist policies. As a new resistance to federal policies emerged and violent guerilla attacks engulfed the state, Southeastern Kentucky's Union support remained firm. A 
combination of strong political and military support from Kentucky's southeastern counties contrasted with the fracturing loyalty found in other regions of the state during the final years of the war.

The thesis concludes with examination of Kentucky's postwar sentiment. Historians have claimed that Kentucky joined the Confederate cause in the aftermath of the war, but the southeastern population chose a post-war Republican identity. Majority support for Republican Union veterans at the federal and state level from Southeastern Kentuckians marked a stark departure from other regions of the state. A lingering pride in Union military service, combined with mountain Unionists' violent encounters with pro-Confederate raiders, hardened the loyal sentiments of the population.

Regardless of origin, motivation, or location, Kentucky men who served in Union Blue contributed to the North's victory. Historian Richard Current Nelson summarized the importance of southern soldiers:

The Union cause was aided by men who did nothing more heroic than garrison posts or guard bridges at some distance behind the lines .... Men of that kind at least made it possible for other soldiers to be released for combat with the rebels. Indeed, anyone who joined the Union army, or who served with loyalist state troops instead, or who merely resisted the Confederate draft helped the cause by depriving the Confederacy of its most desperately needed resource-military manpower. ${ }^{2}$

Historian William W. Freehling took a slightly different stance with Kentucky's early actions in mind. Freehling added:

Kentuckians contributed most to the Union's interval of preparation by what they did not do, namely, disrupt either Grant's or Buell's sanctuary to receive supplies.... By lacking the zeal to harass Yankees who would subdue slaveholders, Kentuckians vindicated what more zealous prewar Southerners had long worried about: The most northern third of the South

${ }^{2}$ Richard Nelson Current, Lincoln's Loyalists: Union Soldiers from the Confederacy (New York: Oxford University Press, 1992), 195. 
might become fatally indifferent to Lower South proslavery preoccupations. ${ }^{3}$

Southeastern Kentuckians contributed in a variety of ways throughout the entire war including State Guard service, as part of large armies engaged in important battles, and, at times, by Freehling's concept of "what they did not do" in effort to deprive Confederates. $^{4}$

Early historians questioned Kentucky's role in the Civil War. E. Merton Colter labeled Kentucky a "pariah" to the Union who aligned with the Confederacy after the war was over. ${ }^{5}$ Modern historians have pushed back on those early claims and found Kentucky's Unionism, particularly at the beginning of the war, essential for the nation's survival. Indeed, Kentucky's choice to remain in the Union made a significant difference in the federal prosecution of the war throughout the conflict. This study illuminates how that one segment of the Kentucky population provided support, endured privation, and remained steady in the face of violence for preservation of the Union. Furthermore, this thesis seeks to establish the role Southeastern Kentuckians played in the Civil War era and to understand how their actions helped the Commonwealth, and the nation, avoid a Confederate fate in a period of contested loyalties.

\footnotetext{
${ }^{3}$ William W. Freehling, The South vs. The South: How Anti-Confederate Southerners Shaped the Course of the Civil War (New York: Oxford University Press), 72.

${ }^{4}$ Ibid.

${ }^{5}$ For a strong rebuke of Coulter's conclusions see Thomas C. Mackey's "Not a Pariah, but a Keystone: Kentucky and Secession," in Sister States, Enemy States: The Civil War in Kentucky and Tennessee, editors Kent T. Dollar, Larry H. Whiteaker, and W. Calvin Dickinson, (Lexington: The University Press of Kentucky, 2009), 25-45.
} 


\section{CHAPTER ONE "GENTLEMEN, I TOO, AM A KENTUCKIAN": KENTUCKY AND THE ELECTION OF 1860}

I.

The election of Abraham Lincoln broke the United States apart. In the Fall of 1860, eligible voters from thirty-three states cast ballots in the federal election-with fifteen of those states still maintaining a legal form of slavery. After decades of sectional political turmoil, the new Republican platform that emerged from the May 1860 Chicago convention —-with its amalgam of northern political interests — signaled, to most southerners, overtures of an unacceptable outlook for the future of the country. Republican promises to limit the spread of slavery to western territories generated much of the South's rejection. However, other planks of the Republican platform, including federal plans connected to western land policy, tariffs, and the building of a transcontinental railroad, raised additional southern concerns about the young Republican Party's proposed role of government in the lives of Americans. The new energy observed in the North's collective commitment to a free labor ideology stoked southern fears about the possibility of a transformed country. Staunch supporters of slavery, with predictions of their own electoral defeat, maneuvered away from the politics of compromise and advocated for an immediate separation. Other citizens from the northernmost slaveholding states rejected such drastic action and offered guarded support with some forming conservative groups such as the Conditional Unionists. In sum, the 
election of 1860 revealed a spectrum of complex opinion regarding the future of slavery and the United States, it uncovered a variety of philosophical and economic outlooks, and it exposed opposing forms of constitutional interpretation.

Leading up to the election, opinions hardened in southerners toward what they feared was a new aggressive hostility toward slavery. Many in the South cast the northern acceptance of the Republican Party as evidence of a potential threat to their entire way of life. Richmond, Virginia and Charleston, South Carolina newspapers seized the opportunity to advance claims of the coming northern industrial drudgery and warned of underlying long-range political plans to transform the South. ${ }^{6}$ The hysteria caused southerners to overestimate northern support for radical efforts to attack slavery where it existed. In fact, the selection of Abraham Lincoln as the candidate to bear the Republican's new program of economic and political reform resulted from an internal effort to find a moderate candidate to thwart the more ambitious antislavery wing of the Republican Party. ${ }^{7}$ As a new political party, less than a decade old, the Republicans wanted to appeal to voters in the southern portions of free states such as Illinois, Indiana, and Ohio. Radical efforts to attack slavery in the South would have produced another electoral loss that resembled Republican John C. Frémont's 1856 presidential campaign against Democrat James Buchanan. Even though the selection of Lincoln multiplied critics on both sides of the slavery argument, in 1860 many Republicans believed that a centrist and moderate approach was crucial for electoral success.

${ }^{6}$ Eric Foner, Free Soil, Free Labor, Free Men: The Ideology of the Republican Party Before the Civil War (New York: Oxford University Press, 1970), 66.

${ }^{7}$ Richard Cawardine, Lincoln: A Life of Purpose and Power (New York: Knopf Publications, 2006), 118-126. 
The 1860 election did not result in a clean, nor quick, political split limited to just two opposing sides. Prior to the wrangling of the National Convention in Chicago, political divisions occurred during the Charleston Democratic Convention within a bloc of southern slave states. Southern fire-eaters, concentrated but not limited to South Carolina, had hoped for secession for over a decade and made up the most extreme group of voters. ${ }^{8}$ But a series of late 1850 s events brought broader swaths of southern opinion closer to their position. The 1857 Scott v. Sandford Supreme Court case that denied freedom to a former slave named Dred Scott, and the outrage that surrounded radical abolitionist John Brown's failed October 1859 raid on Harper's Ferry, combined to either embolden advocates for slavery's expanse or instilled fear of northern abolitionist designs - in many instances the combination accomplished both. ${ }^{9}$ These two crucial developments worked in tandem to create a majority of delegates within the Deep South who rejected the moderate Democrat Stephen Douglas and it caused many southerners to throw their support behind the more hardline proslavery candidate John C. Breckinridge. In addition to the Republican Lincoln and the two competing Democratic candidates, a viable fourth candidate emerged in Constitutional Unionist John Bell to muddle the situation. A former Whig and Tennessee native, Bell promoted a platform of moderation and compromise. The Constitutional Union Party wanted to capture conservative voters put off with the more radical voices coming from the far wings of the Democrat and

\footnotetext{
${ }^{8}$ Douglas R. Egerton, Year of Meteors: Stephen Douglas, Abraham Lincoln, and the Election that Brought on the Civil War (New York: Bloomsbury Press, 2010), 70-76. ${ }^{9}$ For more on the implications of the Dred Scott decision see Earl M. Maltz's Dred Scott and the Politics of Slavery. (Lawrence: University Press of Kansas, 2007). Southern opinion toward John Brown's raid is thoroughly covered in Stephen B. Oates's, To Purge This Land With Blood: A Biography of John Brown (Amherst: The University of Massachusetts Press, 1970).
} 
Republican parties in a schemed effort to peel off enough electoral votes to send the election to the House of Representatives. ${ }^{10}$ The four-candidate race exposed the deep fault lines from the fracturing American political landscape.

An examination of the latitudinal center of the United States reveals the most evidence of a split political opinion during the pivotal 1860 presidential campaign. With the northern-most states offering strong support for the Republican candidate Lincoln, and the Deep South safe in the Breckinridge column, in 1860 the Border States, free and slave, emerged as the most contested region in the election. Pennsylvania and the Midwestern states of Indiana and Illinois helped tip the election of 1856 for Democrat James Buchanan. Those same three states, alongside Ohio and the Upper South, appeared to strategists of the day as the political battleground for the presidency. Historian James McPherson concluded that "the campaign resolved itself into two separate contests: Lincoln vs. Douglas in the North; Breckinridge vs. Bell in the South. Republicans did not even have a ticket in ten southern states ...."11 The five slave states that included Lincoln as a candidate on their ballots produced only a small quantity of votes for the eventual president and various levels of support for each of the other three candidates appeared on the final tallies.

Among the five states that practiced slavery but included Abraham Lincoln as a choice for president was the Republican's birth state-Kentucky. As a former territory of Virginia, the Bluegrass State inherited a strong foundation for the "peculiar institution" of slavery long before 1792 statehood. Kentucky experienced minor efforts to rid the

\footnotetext{
${ }^{10}$ James McPherson, Battle Cry of Freedom: The Civil War Era (New York: Oxford University Press, 1988), 221-222.

${ }^{11}$ Ibid., 223.
} 
commonwealth of slavery during the early debates of its first two state constitutions. After the unsuccessful effort to abolish slavery from the outset, Kentucky moved forward with slavery woven deep into the social and economic fabric of the Commonwealth. A New History of Kentucky estimated the number of 1850 slaveholding families in Kentucky at just over a quarter of total households - a rather large number among the fifteen total slave states. ${ }^{12}$ But an uneven geographical distribution of slave ownership existed within that amount across the state. Most Kentuckians, like most other southerners, never owned slaves because of either cost or, the less likelihood, objection. ${ }^{13}$ Portions of the state not conducive to the financial support of slave labor were another factor. Mountainous regions of Kentucky, like areas of eastern Tennessee, western North Carolina, and western/southwestern Virginia, produced isolated localities separated from the planation life experienced in larger portions of those states. Mountainous locations formed a blend of social bonds and institutions both connected to, and unique from, broader state and national trends.

Perhaps the political traditions experienced in Kentucky's seven decades of statehood did as much, if not more, than geographic factors to distinguish the slave state from the others that held humans in bondage. Many believe that the rise of Henry Clay to national prominence created strong bases of intrastate support for Whig politics. The local Kentucky politicians who supported ideas fundamental to the party's cause benefitted and many of the Commonwealth's citizens developed a level of widespread Whig loyalty not observed in any of the other southern states. Central to Clay's identity

${ }^{12}$ Lowell Harrison and James C. Klotter, A New History of Kentucky (Lexington: The University Press of Kentucky, 1997), 168.

${ }^{13}$ Ibid. 
lay the belief in an American System - a plan that combined federal tariffs, banking, and infrastructure projects to accelerate economic development. ${ }^{14}$ Policies of legislative compromise contributed to Clay's legacy as well. Clay helped Congress navigate through three potential constitutional crises with legislative efforts to heal the nation in 1820, 1833, and 1850. Notable state historian and Clay biographer James Klotter claimed that for those citizens of the Commonwealth who constructed a strong antebellum self-view, "many Kentuckians had been well inculcated in Clay's vision of America and accepted it as their own."15

Recent scholarship also points to a deeper economic picture as the primary catalyst for Kentucky's antebellum political leanings. In James A. Ramage and Andrea S. Watkins's Kentucky Rising: Democracy, Slavery, and Culture from the Early Republic to the Civil War, the authors argued that Jeffersonian Republicanism declined in Kentucky in the pre-war decades. ${ }^{16}$ Ramage and Watkins suggested that many elements of the pure Jeffersonianism that dominated southern political culture ran counter to the idea of the numerous "frontier men and women [who] came to Kentucky for the opportunity to work hard, earn money, and rise in society; [they had] no intention to live poor in a poor man's country." "17 Evidence of a distinct economic mindset was present throughout the four decades prior to the Civil War when Kentuckians displayed a devout

\footnotetext{
${ }^{14}$ For more on Henry Clay see Robert Remini, Henry Clay: A Stateman for the Union (New York: WW Norton \& Co., 1991) and James Klotter, Henry Clay: The Man Who Would Be President (Oxford: Oxford University Press, 2018).

${ }^{15}$ James C. Klotter, "Kentucky, the Civil War, and the Spirit of Henry Clay," The Register of the Kentucky Historical Society, 110, (2012), 251.

${ }^{16}$ James A. Ramage and Andrea S. Watkins, Kentucky Rising: Democracy, Slavery, and Culture from the Early Republic to the Civil War, (Lexington: The University Press of Kentucky, 2011).

17 Ibid., 89.
} 
political loyalty and provided reliable vote returns for Whig candidates - a trend not observed in any other southern state. Most of the South, in those same years, offered near unwavering support for Jeffersonian, and later, Jacksonian candidates. Henry Clay's influence was the most common conclusion for historians seeking to explain the motivation of Kentucky's political behavior during that period. However, instead of the talented Clay directing the state's political whims, sentiment from the population may have at least aligned, or at most shaped, Henry Clay's core convictions. Jeffersonian purity and Jacksonian philosophy stood at odds with federal guidance in economic policy - and sometimes the two political movements produced politicians quick to challenge federal authority. Historian Stephen Fackler claimed early Kentuckians "wanted secure land titles, cheap money, and relief from debts. But most were unwilling to flout the Constitution to achieve their ends." ${ }^{18}$ This opinion led many Kentucky homesteaders to vote from the economic and political perspectives that they found in “Henry Clay’s and Alexander Hamilton's nationalistic vision to succeed in diversified farming."19 The election of 1860 reflected interesting residues of Kentucky's decades long political heritage.

Closer examination of the voting citizens of Kentucky in 1860- drawn from a population of just over one-million and one-hundred thousand $(1,155,684)$ residentsrevealed a complex picture of the presidential election. The state held the ninth largest

\footnotetext{
${ }^{18}$ Stephen W. Fackler, "John Rowan and the Demise of Jeffersonian Republicanism in Kentucky, 1819-1831," The Register of the Kentucky Historical Society Volume 78 (1980), 23.

${ }^{19}$ Ramage and Watkins, Kentucky Rising, 89.
} 
population total in the Union and the third most among slave states. ${ }^{20}$ Of the presidential candidates' success in Kentucky, Constitutional Unionist John Bell received (45.2\%) 66,501 votes, Southern Democrat John Breckinridge (36.4\%) 53,143, Northern Democrat Stephen Douglas (17.5\%) 25,638, and Republican Abraham Lincoln (0.9\%) 1,364. Nationally, Bell carried the Bluegrass State along with Virginia and Tennessee. To the west, Stephen Douglas carried neighboring Missouri. These four states' results reflected the Upper South's reluctance to vote in lockstep with the Deep South or with the Republicans of the North. The returns from Kentucky signaled a desire to avoid the more extreme candidates in search for either a moderate politician or a compromise to deal with the national emergency. Breckinridge secured a narrow victory in Maryland and scored his only comfortable win in the entire Border Region with Delaware's small population. The aftermath of the 1860 election produced, and continues to produce, a multitude of speculative questions from political observers and historical scholars alike. One can only guess where Kentucky’s Bell voters would have turned had Bell not run. A unified Democratic ticket may have carried all the southern states and made larger gains into the Midwest. Seldom asked, however, are two-related questions, specific in nature but worthy of historical attention: where was Lincoln's minimal support in Kentucky and what drove that support?

Lincoln's lack of political appeal throughout the entire South resulted from the Republicans' strong stance against slave expansion in the West. Traditional voters of the Whig party, the previous opposition to the Democrats, did not transition into the ranks of

${ }^{20}$ Kenneth H. Williams and James Russell Harris, "Kentucky in 1860: A Statistical Overview," The Register of the Kentucky Historical Society, 103, (Autumn 2005), 751. 
Republicans in the South during the 1850 s as happened in the North. Instead, many searched for a middle ground and joined various parties such as the nativist KnowNothings, the American Party, and the Constitutional Unionists. Conservative citizens opposed to Democratic threats of secession, but not ready for an attack on southern slavery, wandered in a "political desert" where consensus was slow to coalesce. ${ }^{21}$ Many former southern Whigs, alarmed at new attitudes toward slavery, tossed their lot in with the Democratic Party and acted as moderates. Regardless of party affiliation, larger segments of the Border State electorate, including Kentucky, feared that the "election of a Republican president would galvanize the northern and southern extremists." 22 Abraham Lincoln's background and Kentucky roots did little to attract a significant number of Kentucky voters in favor of the Republican candidate.

Born in 1809 in Hardin County to parents Thomas and Nancy Lincoln, Abraham Lincoln came from a typical early Kentucky family. The Sinking Spring Farm represented then, and still symbolizes today, a frontier opportunity to advance up the American social ladder. But Kentucky's rampant issues with clear land titles dampened that opportunity in the early 1800s and the Lincolns moved to another nearby farm at Knob Creek. Abraham Lincoln's first seven years of life brought exposure to the Kentucky frontier lifestyle including the hard realities associated with rugged farming,

\footnotetext{
21 Thomas C. Mackey, "Not a Pariah, but a Keystone: Kentucky and Secession," in Sister States, Enemy States: The Civil War in Kentucky and Tennessee, editors Kent T. Dollar, Larry H. Whiteaker, and W. Calvin Dickinson, (Lexington: The University Press of Kentucky, 2009), 29.

${ }^{22}$ Christopher Phillips, The Civil War in the Border South, (Santa Barbara: Praeger, 2013), 5.
} 
limited educational opportunities, and even a near drowning. ${ }^{23}$ In 1816 , the Lincoln family moved across the Ohio River to a location in Indiana. Even though the move meant a permanent departure from the Commonwealth, the future president continued to develop important relationships connected to Kentucky for the rest of his life. Wife Mary Todd, law partner William Herndon, best friend Joshua Speed, and newspaper editor George Prentice of the Louisville Journal stand out as a few examples of the many Kentuckians who surrounded and influenced Abraham Lincoln. ${ }^{24}$ Aside from the long list of direct Kentucky relationships, perhaps political influence represented a more important aspect of potential appeal for voters in 1860. Historian Stephen Oates wrote:

Like his father, young Lincoln was a Clay man and "all but worshipped his name." He liked Clay's ringing nationalism. He liked Clay's economic program, whose goal of sectional interdependence and national unity appealed to Lincoln's love of logic, of symmetry and stability. And he liked Clay's stand on slavery and colonization." 25

As a staunch Whig, Abraham Lincoln's political career, until his election as president, resulted in more defeats than victories. Illinois leaned toward Jacksonian candidates in the time of Lincoln's earliest races for public office. The mid-term election of 1846 provided one bright spot in a long list of defeats when local leaders of the Whig party, along with Illinois voters, awarded Lincoln a two-year legislative term, 1847-1849, in the United States House of Representatives. Lincoln's commitment to towing the Whig Party line from his Illinois days made little impression on most of the voters in

${ }^{23}$ The historiography on Abraham Lincoln's early biography is large. Lowell Harrison's Lincoln of Kentucky (Lexington: University Press of Kentucky, 2000); David H.

Donald's Lincoln (New York: Simon \& Schuster, 1995) offer some of the most useful analysis on Lincoln's first years in Kentucky.

${ }^{24}$ Harrison, Lincoln of Kentucky, vii.

${ }^{25}$ Stephen B. Oates, With Malice Toward None: A Biography of Abraham Lincoln (New York: Harper \& Row, 1977), 21. 
Kentucky during the 1860 election. Paradoxically, Lincoln's political philosophy paired much better with his native Kentucky during the 1830s and 1840s than it did in Illinois. However, enough had changed in the minds of Kentucky voters during the 1850 s to marginalize any benefit from Lincoln's history of Whig loyalty going into the 1860 election.

Attitudes toward slavery and disunion accounted for the biggest challenge in the political environment that Abraham Lincoln encountered in Kentucky. The Kentucky sentiment against disunion damaged John Breckinridge's ability to carry the state, but those same threats connected to the Breckinridge candidacy also influenced opinion against Abraham Lincoln. As 1920s historian E. Merton Coulter surmised:

As threats were frequently heard from the South during this campaign that secession must follow if Lincoln is elected, the Breckinridge Democrats were assaulted on all sides by their Kentucky opponents with the charges of standing for disunion. Their party was committed to secession, it was said, if Lincoln succeeded. Their candidate, Breckinridge, was a disunionist. ${ }^{26}$

This political sentiment resulted in an act of collective self-interest for a substantial number of Kentuckians who wanted to avoid the violence that might engulf the state. Breckinridge garnered the vote of those who put slavery above all else, but Lincoln had no real constituency in Kentucky for appeal. Instead, his possible victory represented a real threat of future trouble to most Kentuckians. John Bell benefitted the most in this political climate. Historians attribute Bell's appeal in the Border States to the large number of voters who sought to protect the state from becoming an up-close battleground for the conflict. Scores of Douglas supporters might fit a similar categorization. In

${ }^{26}$ E. Merton Coulter, The Civil War and Readjustment in Kentucky, (Chapel Hill: The University of North Carolina Press, 1926), 22. 
judgement of the immediate aftermath of the election when Kentuckians rejected secession, Coulter provided a similar conclusion:

But here on this borderland the preservation of the Union and the preservation of slavery went hand in hand; for if the country divided, Kentucky would almost sure to be on the frontier, regardless of which side she should choose. The destruction of the Union would sound the doom of slavery; for if she went with the South, it would make the northern banks of the Ohio a refuge for fugitive slaves, and if she should go with the free North she could not hope to maintain slavery long. It took no great amount of foresight to show that disunion must ultimately destroy slavery in Kentucky. ${ }^{27}$

If this opinion was prevalent in Kentucky after the election, amidst a wave of secession, one could reason that some semblance of the same line of thought influenced voters' choices during the election. In a desperate pitch for union, Kentucky voters felt compelled to reach for a kind of hopeful status quo. The final election results from Kentucky in 1860 reflect such a conclusion. The political positions of the four candidates left a small bloc of voters who were either ardent enough against slavery to disregard the threats of disunion or with enough political desire for change to reject the self-preserving sentiments as the only constituency for Lincoln to capture in Kentucky. Few voting Kentuckians arrived at such a position.

II.

In 1860, one-hundred and ten counties comprised Kentucky. Of those numerous counties in the election of 1860, Jackson County offered Republican Abraham Lincoln his greatest Kentucky support. Jackson County, carved out of portions of Madison, Estill, Owsley, Clay, Rockcastle, and Laurel counties in 1858, represented one of the

${ }^{27}$ Ibid., 12. 
youngest counties of the nation on the eve of the Civil War. ${ }^{28}$ Jackson County lies near the center of the Kentucky Appalachian Mountain chain that cuts in a diagonal line across the southeastern portion of the state. The northwestern-most boundary of the county adjoined Madison County and acted as a passage into the central Bluegrass Region of the state. The inaugural population of Jackson County in the 1860 census recorded 3,087 residents. The number of slaves included in that same count totaled seven and belonged to four separate slaveholders. Of the other thirteen Appalachian counties classified as "Southern Eastern Highland" counties, all boasted slave populations of seventy or more, with eleven of the total fourteen counties that listed over one-hundred slaves each. ${ }^{29}$ In short, each county in the region had at least ten times more slaves than Jackson County and adjacent Estill County possessed the most with over five-hundred. For comparison, just to the north, in the "Lexington/Inner Bluegrass Region," Madison County recorded over six-thousand humans in bondage. ${ }^{30}$ The census listed twenty-one free blacks for Jackson County, amounting to the only county in the region, and state, and possibly the entire South, with a number of free blacks that surpassed the number of slaves.

Statewide, Jackson County possessed the fewest number of slaves.

Of the 390 votes counted in Jackson County for the 1860 presidential election, over a quarter (25.8\%) went to Lincoln. The next two highest percentages of Republican voters in the state occurred in the two Ohio River counties of Campbell (11.9\%) and

\footnotetext{
28 "Report on the History of Jackson County to 1918 by Isaac Anderson Bowles," retyped and mimeographed by the Public Relation and Power Use Department of Jackson County R.E.C.C. in McKee KY, (1974), located in the Jess Wilson Collection at the Clay County Historical Society, Manchester Kentucky.

${ }^{29}$ Williams and Harris, "Kentucky in 1860: A Statistical Overview," 750.

${ }^{30}$ Ibid., 748.
} 
Kenton (7.5\%). ${ }^{31}$ For comparison, in forty-five counties statewide, nearly half of the Commonwealth, Lincoln received either one or zero votes. ${ }^{32}$ The finally tally in Jackson County awarded Constitutional Unionist John Bell 140 votes, Southern Democrat John Breckinridge 136 votes, Republican Abraham Lincoln 101 votes, and Northern Democrat Stephen Douglas 13 votes. The newly formed county voted with Kentucky in the selection of John Bell as its winner but provided Abraham Lincoln some of his strongest support from any area in the nation with legal slavery. The near absence of slavery attributed to this total, but elements of abolitionism made an impact as well.

More so than other slave states, Kentucky experienced limited, yet important, abolitionist activity. As a Presbyterian minister, David Rice rose as one of the earliest Kentucky voices against slavery. ${ }^{33}$ Rice's pamphlet Slavery Inconsistent with Justice and Good Policy attacked slavery in Kentucky from a religious and moral standpoint during the earliest statehood debates in 1792. Rice predicted that the end of slavery would transform Kentucky into a more virtuous society and would boost an influx of "useful" citizens. ${ }^{34}$ Another Kentucky minister, Baptist David Borrow, took a similar stance against the institution of slavery. Borrow published a fifty-five-page pamphlet in 1808 that denounced the limited opportunities afforded to blacks and argued that the Kentucky economy drove inequality among the entire population. ${ }^{35}$ In 1821 , the Kentucky Abolition Society published a year-long series of monthly newsletters entitled Abolition

\footnotetext{
${ }^{31}$ Ibid., 763.

${ }^{32}$ Ibid., 762.

${ }^{33}$ Harrison and Klotter, A New History of Kentucky (1997), 174.

${ }^{34}$ Ibid.

${ }^{35}$ Ibid., 175.
} 
Intelligencer and Missionary Magazine edited by another minister, John Finley Crowe. ${ }^{36}$ Abolitionists and emancipationists advocated for change and operated early in Kentucky's history. In the 1830s another group emerged in the antislavery effortproponents for colonization.

The American Colonization Society rose as a suitable alternative for many Kentuckians put off by radical abolitionism. The fundamental mission of colonization included the emancipation of slaves coupled with deportation to the African colony of Liberia. Thirty-one colonization societies existed in Kentucky in 1832 and Henry Clay emerged as one of the scheme's leading figures. Pulitzer Prize winning historian Eric Foner assessed the appeal and evolution of colonization in places like Kentucky. Foner claimed, "Planters and political leaders from the Upper South dominated the American Colonization Society. Few were more adamant about linking colonization with emancipation than Henry Clay." 37 The Kentucky-backed approach later echoed with Abraham Lincoln and Foner added:

Clay's outlook on slavery-condemnation of the institution and affirmation of the blacks' humanity coupled with the conviction that emancipation could only come gradually and should be linked with colonization - strongly affected Lincoln's. More than once during the 1850s when speaking about slavery and race, Lincoln quoted or paraphrased Clay. "I can express all my views on the slavery question," he once said, "by quotations from Henry Clay." 38

Colonization drew contemporary criticism, and for modern Americans, the practice appears in hindsight as an inhumane solution to a vile institution. While many of these assessments are undeniable, in mid-nineteenth century Kentucky, colonization became

\footnotetext{
36 Ibid.

${ }^{37}$ Eric Foner, The Fiery Trial: Abraham Lincoln and American Slavery (New York: W.W. \& Norton, 2010), 18.

${ }^{38}$ Ibid., 18-19.
} 
the most attainable end to slavery for those committed and willing to lend their voice to stop human bondage within a slave society.

Supporters of colonization and other emancipationist efforts moved the debate over slavery to the forefront of Kentucky political thought in the antebellum years. Kentuckians agreed to call a third constitutional convention in 1848 . While the primary purpose of the convention centered upon a growing state debt, legislative spending, spoils, and gerrymandered districting; eager Kentuckians, against slavery, inserted the issue for discussion. ${ }^{39}$ Debates across the state turned violent while those opposed to slavery remained hopeful for some type of political success. In the end, however, the new 1850 Kentucky Constitution not only fell short to the hopes of those against the practice of slavery, but the whole process strengthened the institution and provided a serious setback to the abolitionists and emancipationists in the state. ${ }^{40}$ In addition, the proslavery victory emboldened advocates to further antagonize and silence opponents of slavery. Even with Henry Clay as an admired advocate of colonization, and numerous moderate citizens seeking to move the Commonwealth away from slavery, the abject failure of antislavery measures in 1849 secured slavery's immediate future in Kentucky. The political victory further empowered slavery's supporters and even pushed some frustrated Kentucky abolitionists to look for residence in other states. ${ }^{41}$

Areas in Southeastern Kentucky experienced only limited exposure to antislavery efforts prior to the 1830 s and 1840 s. Much of the historical record trace early efforts of Kentucky abolitionism to the central and northern portions of the state where slavery

\footnotetext{
${ }^{39}$ Watkins and Ramage, Kentucky Rising (2010), 270.

${ }^{40}$ Ibid., 271-273.

${ }^{41}$ Harrison and Klotter, A New History of Kentucky (1997), 178.
} 
thrived. A far higher percentage of the state's slave population accompanied the location of the bourgeoning communities and economy of the central Bluegrass Region. The Jackson Purchase and other portions of Western Kentucky also surpassed Appalachia in both free and slave populations in the decades following statehood. The counties south of Lexington and east of Bowling Green remained isolated in this American period of economic growth. But Appalachian Kentucky was not devoid of slavery, nor of citizens interested in the issue. Estill, Clay, and Knox Counties combined to list 1,345 slaves in the 1860 census. ${ }^{42}$ Political and religious developments brought voices opposed to slavery to mountainous areas as attention to the issue rose on at the national level.

Cassius Marcellus Clay and John Gregg Fee became the two most significant figures associated with abolitionism in Southeastern Kentucky. ${ }^{43}$ The two men were of different backgrounds, possessed different philosophies on how to rid the nation of slavery, and held conflicting views on matters of self-defense-views often challenged by angry Kentucky mobs. But both Clay and Fee shared a common passion against the institution of slavery, and both wanted to convince Kentuckians of slavery's detrimental effects on society. The citizens of Appalachia Kentucky, overall, were more receptive to antislavery and abolitionist messages than their northern or western Kentucky neighbors. Clay delivered a political approach and Fee appealed with a religious one.

Cassius Clay, as a prominent politician, took a more aggressive stance against slavery than did his Kentucky counterparts. Cassius bore the same last name as Kentucky's most famous statesman, and older cousin, Henry Clay. Educated at Yale,

${ }^{42}$ Williams and Harris, "Kentucky in 1860: A Statistical Overview," 750. ${ }^{43}$ Christopher Phillips, The Rivers Ran Backwards: The Civil War and the Remaking of the American Middle Border (New York: Oxford University Press, 2016), 64-65. 
Cassius Clay heard William Lloyd Garrison speak during the abolitionist's rise to become one of the nation's most important voices against slavery. Clay's educational experience and exposure to abolitionism brought northern viewpoints into Kentucky. Furthermore, Clay's success in Whig politics and adherence to Henry Clay's economic programs of a commercialized economy worked to manifest his antislavery views in favor of a transformed Kentucky economy. In the 1844 presidential race between Democrat James K. Polk and Whig Henry Clay, Cassius campaigned on Henry's behalf in the North. The Whigs needed Cassius Clay's antislavery bona fides to attract wavering northern voters and, on one occasion, Clay followed famous Massachusetts senator Daniel Webster in a series of speeches delivered on Boston Common. Cassius Clay aimed his efforts, as a spokesman of the South and advocate for Henry Clay, at securing abolitionists who were tempted to vote for third-party candidate James G. Birney. ${ }^{44}$ With Boston as a hub of abolitionist activity that included devout followers of Garrison's ideas found in The Liberator, the task represented a show of political confidence in Cassius Clay's ability to appeal to northerners. But the Kentuckian stopped short of the Garrisonian brand of abolitionism noted for overt criticism of America's founding and constitution. Instead, Clay judged that Garrisonian "abolitionists committed the grave error of attacking the Constitution; their efforts brought disruption to the Union rather than a rational solution to the problem of slavery." 45 While William Lloyd Garrison converted numerous readers with more radical and immediate solutions to ending slavery, those views would have driven away Kentuckians. Cassius Clay's positions made him a moderate in the North

\footnotetext{
${ }^{44}$ H. Edward Richardson, Cassius Marcellus Clay: Firebrand of Freedom (Lexington: University Press of Kentucky, 1976), 39-40.

${ }^{45}$ Ibid.
} 
and, in the South, as close to a radical as possible with any ability to retain a degree of influence. The political straddle brought numerous threats of bodily harm to Clay, to which he responded in kind.

Cassius Clay earned the nickname "the Lion of White Hall" while defending his ideas and his Kentucky home. Situated between the Bluegrass region and the Appalachian Foothills, Clay's White Hall estate in northern Madison County made for a location resembling his national political reputation — positioned between two different bodies of opposing opinion. Resorting to violence for self-protection is where Clay drew his biggest distinction from other opponents of slavery around the nation. Clay's 1845 antislavery publication of the True American earned him quick scorn and numerous threats from proslavery forces around Central Kentucky. Cannons, powder, muskets, and other arms lined his printing office as a lethal warning to intruders committed to silencing his paper or doing him bodily harm. ${ }^{46}$ Determined not to suffer a fate like the murdered abolitionist Elijah Lovejoy of Illinois, Clay's armed efforts allowed subscriptions of the Lexington based paper to climb to over 3,000 in the publication's duration. In 1849, during the contentious debates of Kentucky's election of delegates for a third state constitutional convention, Clay debated proslavery candidate Squire Turner in Madison County. Turner's son Cyrus took exception to Clay's comments and approached the podium. A scuffle ensued between Clay and several proslavery men before an injured Clay fatally stabbed Cyrus Turner with a Bowie Knife. ${ }^{47}$

\footnotetext{
${ }^{46}$ Ibid., 43-46.

${ }^{47}$ Ramage and Watkins, Kentucky Rising (2010), 271-272.
} 
John Fee joined with Cassius Clay in the 1850s. Fee, a Kentucky born minister trained at Lane Theological Seminary, befriended Clay in the late 1840s. The two formed a bond to oppose slavery when Clay gifted a portion of land in southern Madison County, near Jackson County, for the purposes of a school. Fee's belief of racial harmony and opportunity positioned him as a radical outsider in slave state Kentucky. Glade, the name of the land Fee received, later became better known as Berea. The American Missionary Association, a protestant-based abolitionist group from New York, offered some material aid and kept close ties with Fee's progress. Clay's reputation offered a degree of security for Fee to operate, but the pastor faced multiple incidents of proslavery harassment of his own. As Fee's southern abolitionist experiment expanded, the founder of Berea needed additional help.

George Candee was born in 1831 — the same year that literate preacher Nat Turner led America's most violent slave rebellion in Virginia and the same year William Lloyd Garrison launched The Liberator. Candee attended Oberlin College and later graduated from Oberlin Theological Seminary just outside of Cleveland in 1857. When Oberlin adopted the policy of admitting students "irrespective of color," the only college In America to do so, the institution attracted national attention. ${ }^{48}$ The American Missionary Association recognized the young pastor's talents and Candee preached in Appalachia under the auspices of the organization. In 1913, The Berea Citizen conducted an interview with Candee from his Ohio home and published an extended work on his recollections of antebellum and Civil War experiences in Southeastern Kentucky in a

\footnotetext{
${ }^{48}$ Cally L. Waite, "The Segregation of Black Students at Oberlin College after Reconstruction," History of Education Quarterly, Vol. 41 (Autumn, 2001), 344, published by Cambridge University Press, JSTOR (369200).
} 
series entitled "Reminiscences." ${ }^{49}$ Candee introduced himself to readers, "I was a born Abolitionist. My father was the keeper of an Underground Railroad station." ${ }^{, 50}$ Interest related to travel and residence in the South first arose in Candee in 1854 when two Oberlin friends, Humphrey Marshall and O.B. Waters, selected Kentucky as the destination to teach students. With Marshall and Waters planning to take up work in Kentucky, Candee's burning desire to join John G. Fee and offer his services for the leader's abolitionist effort overtook him, and he accompanied the duo on a trip scheduled for northern Kentucky. ${ }^{51}$ Aboard the train to Cincinnati, with expectations to rendezvous with John Fee just across the Ohio River, Candee opened a letter that informed him of John Fee's relocation to southern Madison County. Candee used most of his remaining money to get further south to Lexington and held only twenty-three of the twenty-five cents needed for the additional stagecoach to Richmond. ${ }^{52}$ The driver accepted the fare as sufficient and Candee arrived penniless in Richmond, Kentucky.

The young pastor walked south from Richmond in search of Fee and Cassius Clay's antislavery community. Aware of the danger, Candee recollected:

I did not mention [Cassius] Clay's name until I heard it well spoken of at Rogersville. I was afraid enemies of Mr. Fee and Mr. Clay would misguide me - or do something worse. They had quite recently ducked a 'wild' Abolitionist - repeatedly in a watering pond until he swore with his hands on his own Bible that he would leave the State and never return. ${ }^{53}$

Candee, also aware of Clay's designs for Berea, referred to John Fee as "a sort of bishop in that central place over all his anti-slavery constituency for political reform purposes." 54

\footnotetext{
${ }^{49}$ The Berea Citizen, Jul. 10, 1913.

${ }^{50}$ The Berea Citizen, Jul. 24, 1913.

${ }^{51}$ Ibid.

${ }^{52}$ The Berea Citizen, Jul. 31, 1913.

${ }^{53}$ Ibid.

${ }^{54}$ Ibid.
} 
If Fee was the bishop, Candee seemed poised to act as an itinerant for his message. One of the earliest experiences for Candee included delivering sermons in the winter of 1855 just outside of Berea. Soon thereafter, George Candee found himself located further into the southern Appalachian Mountains.

Jackson County and Candee became interwoven around the county's inception in 1858. Theophilus Tolman (T.T.) Garrard, Levi Jackson, and representatives from seven separate counties met in March to finalize plans for creation of Jackson County. ${ }^{55}$ Early settlers selected McKee as the county seat. Local residents, Jerman Thompson, and later Solomon Stephens, offered Candee overnight hospitality as he travelled and awaited his move into central Jackson County. ${ }^{56}$ Candee claimed himself as the first person to move into McKee and estimated that the entire county did not have a "half dozen slaves," but did have "quite a list of radical abolitionists. .."57 Among these abolitionist inhabitants was a man who mirrored Cassius Clay's violent style of self-preservation-Bob Nichols.

Bob Nichols lived in the southern portion of Jackson County at a location called Moores Creek. Nichols read classics such as Newton's Principia, Harriet Beecher Stowe's Uncle Tom's Cabin, along with a host of other antislavery and abolitionist publications. ${ }^{58}$ Upon greeting, Nichols recited on frequent occasion that he was "an abolitionist, a patriot, and a lover of my country" as a common introduction. ${ }^{59}$ Described

${ }^{55}$ A Portrait of Jackson County: 1858-2008 (Virginia Beach: Donning Company Publishers, 2008), 18. This book was produced by the Jackson County Development Association in recognition of the $50^{\text {th }}$ anniversary of the county's existence. The book offers the best collective history focused on Jackson County.

${ }^{56}$ The Berea Citizen, Sept. 13, 1913.

${ }^{57}$ The Berea Citizen, Sept. 25, 1913 and The Berea Citizen, Oct. 16, 1913.

${ }^{58}$ The Berea Citizen, Oct. 16, 1913.

59 Ibid. 
as a "fist and skull pugilist," Nichols fought back against proslavery in a violent manner. Just more than a year after Candee's arrival in McKee, a neighboring Madison Countian, Wash Maupin, traveled to Jackson County to collect information on Candee and his followers. The effort followed John Brown's raid at Harper's Ferry in Virginia and came after a proslavery mob chased John Fee from his Berea home and out of Kentucky. When Maupin arrived in McKee hoping to initiate plans for a similar outcome for George Candee, local Jackson Countians informed Maupin that if a Madison County mob marched to McKee—armed citizens would meet any effort to harm Candee. According to a witness, the strong rebuke caused a threatened Maupin to ride in fear for the county line. ${ }^{60}$ George Candee avoided the 1859 political exile that John Fee experienced. The threat of mob violence, however, would return.

Proslavery advocates whipped Jackson Countians into another frenzy following the Maupin incident. An aide to Candee, Jim Seaborn returned to a Jackson County post office one morning with news of another hatched plan for proslavery mob violence. Seaborn rode south, horseback, for over ten miles to alert Bob Nichols at his Moores Creek home of the proslavery threat. Around 2:00 A.M. Nichols, a Baptist minister, and several other armed citizens arrived at McKee to protect Candee. Townsfolk later discovered the threat false and that a town drunk promulgated the entire alarm. Most of the men spent the night in McKee and walked around the streets of the town, armed, the next day in a show of force. ${ }^{61}$ A Richmond Kentucky newspaper, The Mountain Democrat, reported sixty armed men opposed to slavery who came out to protect Candee.

\footnotetext{
${ }^{60}$ Ibid.

${ }^{61}$ Ibid.
} 
Perhaps in a stroke of irony, a frustrated John Fee at one time protested to the American Missionary Association in 1857 that to have "the protection of a civil officer will not be wrong. Paul [the apostle] had an escort of 60 horsemen on one occasion." 62 Candee received the protection Fee desired from local residents willing to fight for his safety.

The combination of a religious Candee and a political Nichols appeared to parallel, in many ways, the early relationship of Fee and Clay. Through Candee's traveling sermons, interaction with residents at Estill County's Station Camp, Rockcastle County, and areas of northern Laurel County brought the pastor into contact with abolitionist sympathies just across Jackson County lines. ${ }^{63}$ Candee wrote of warm receptions and of the courteous hosts found in his frequent religious meetings with numerous Appalachian citizens. Bob Nichols admired Cassius Clay's political abilities and welcomed the Lincoln spokesperson to Jackson County in 1860. Candee recalled:

While a radical Republican, [Clay] parted with John Fee and other radical abolitionists who championed immediate abolition. He did not stand by the Bereans at the time they were mobbed out of the state but did some damaging characterizing of Brother Fee for which I criticized him in a private letter. $^{64}$

In recollection of the period just before the 1860 election, Candee stated:

[Clay] was a little fearful of the Jackson County radicals. But when the [1860] election campaign was on, the radicals and the conservatives of Jackson County united and called Clay to come up and give us a Republican speech. I was appointed committee to send him the invitation; which service I performed as gracefully as I could, inviting him to be my guest. ... A great mass of people greeted him. I doubt if a single man in Jackson County who was able to be there was absent. ${ }^{65}$

\footnotetext{
${ }^{62}$ Stanley Harrold, "Violence and Nonviolence in Kentucky Abolitionism," The Journal of Southern History, Vol. 57, (Feb., 1991), 27.

${ }^{63}$ The Berea Citizen, Oct. 23, 1913 and The Berea Citizen, Jan. 15, 1914.

${ }^{64}$ The Berea Citizen, Jan. 22, 1914.

${ }^{65}$ Ibid.
} 
A banquet followed, and Bob Nichols and his wife provided a portion of the food. Clay spoke to Candee and expressed his surprise about such safety and enthusiastic support. ${ }^{66}$ In a May 1860 correspondence with the future president, Clay promised to raise as much support as possible for the election. Lincoln wrote back:

I shall, in the canvass, and especially afterwards, if the result shall devolve the administration upon me, need the support of all the talent, popularity, and courage, North and South, which is in the party; and it is with sincere gratification that I receive this early indication of your unwavering purpose to stand for the right. ${ }^{67}$

Candee and Nichols's relationship did not deteriorate over politics as did Fee and Clay's. Nor did Nichols abandon the protection of his local abolitionist pastor as Fee supporters accused of Clay. After the shelling of Fort Sumter in 1861, Candee did leave the state and pro-Confederate sentiment seemed to rise in the county he left behind. However, Candee received a letter only a few weeks after his departure that relayed news of the quelling of Confederate voices led, no doubt, by Bob Nichols and men like him.

\section{III.}

The events in McKee appear to exist as one of the only real examples of success related to Cassius Clay's earlier promise to raise political support for the presidential candidate Abraham Lincoln. Of the 1,364 Kentucky votes counted for Lincoln in the election of 1860, 101 Jackson Countians, 56 Estill Countians, 64 Rockcastle Countians, and 10 Laurel Countians - all in proximity of McKee influence — cast their votes for the Republican candidate. The amount accounted for nearly $20 \%$ of Lincoln's total

\footnotetext{
66 Ibid.

${ }^{67}$ Abraham Lincoln, The Collected Works IV, 1860-61 (New Brunswick: Rutgers University Press, 1959), 53.
} 
Kentucky vote, but the defined boundary of the populations where the votes appeared made up less than $1 \%$ of Kentuckians.

John Bell's Constitutional Unionism peeled away many of Kentucky's traditional Whig voters. Even without his candidacy, the support of Lincoln may have only made marginal gains. Samuel Haycraft, a Whig and Union man, tried to convince Lincoln to campaign in his birth state during the 1860 race. After Lincoln denied that request, he wrote Haycraft a letter where he offered an optimistic outlook: "Rest fully assured that the good people of the South who will put themselves in the same temper and mood towards me which you do, will find no cause to complain of me." ${ }^{\prime 68}$ The results proved otherwise.

A strong stance either against slavery or for abolitionism emerged as the only constituency for Lincoln to capture in Border States where sentiments for slavery and/or safety existed as the two most important issues. Opponents of slavery in Kentucky, and the nation, witnessed how events and movements in the 1850s eroded the modest gains of previous decades. Increased sectionalism also made it difficult for moderates to justify positions that could jeopardize the future political standing of their respective regions of the country. Abraham Lincoln's non-appearance on ten states' presidential ballots exemplified the level of opposition his candidacy faced.

Jackson County's location, economy, and isolation made for an exception. Appalachian southerners did not benefit from the slave economy and many of the mountain residents harbored suspicions towards the institution. With Cassius Clay's

${ }^{68}$ As quoted in Michael Davis's, The Image of Lincoln in the South (Knoxville: The University of Tennessee Press, 1971), 18. 
example only miles away, one can only wonder how much influence penetrated the area before the county's 1858 formation. Instead, the vote tally and stories of pastor George Candee present the most tangible evidence of the small population's political departure from the rest of the state. But the label anomaly, the term most often used to describe the political action of mountain whites, sells short the values, commitment, and convictions of a people who voted and supported an idea. Isolation and the physical environment hardened abolitionists of Appalachia. Historian Stanley Harrold added:

Their experience with the issue of violent means in confronting a social evil within their society demonstrates the limits of peaceful reform in a slave state and suggests the dynamic interaction of abolitionist ideas and southern culture. As members of that culture seeking fundamental change, the Kentucky abolitionists may provide a better paradigm of the predicament of American reformers than abolitionists in the North, who usually confronted slavery only from a great distance. ${ }^{69}$

Proslavery advocates willing to engage in violent intimidation forced Kentucky abolitionists to develop systems of protection or risk being silenced. The residents of Southeastern Kentucky reflected this conclusion. The effects raged from their courage in ballots to the protection of a northern stranger.

After winning the election, Abraham Lincoln wrote a speech intended, but never delivered, for a Kentucky audience. The remarks would have been part of Lincoln's communication to Americans along the journey to his inauguration. Seven states chose secession before Lincoln took office, but the speech would have appealed for Kentucky to accept the constitutional process.

Is there a Bell-man, a Breckinridge-man, or a Douglas man . . . amongst you would not die by the proposition, that your candidate, being elected, should be inaugurated, solely on the conditions of the constitution, and

${ }^{69}$ Harrold, "Violence and Nonviolence in Kentucky" (1991), 38. 
laws, or not at all. What Kentuckian, worthy of his birthplace, would not do this? Gentlemen, I too, am a Kentuckian. ${ }^{70}$

${ }^{70}$ Abraham Lincoln, Collected Works IV (1959), 200. 


\section{CHAPTER TWO \\ "THE UNION SENTIMENT AMONG THE PEOPLE LARGELY PREDOMINATES:” SOUTHEASTERN KENTUCKY IN 1861}

In the state of Kentucky during the Civil War era, the southeastern Appalachian population provided a great amount of loyalty to the Union in sentiment and action. The philosophies and outlooks that drove this staunch Unionism has long evaded and frustrated many Kentucky Civil War scholars. Some historians dismiss the contributions as a southern anomaly, others question the depth and significance of the loyalty of that region. The simple conclusion many researchers put forth is that the area's lack of a slave economy caused Kentucky's Appalachian residents to develop either a natural antislavery mentality or an isolated indifference. Records and events, however, suggest that significant portions of the population from Kentucky's southeastern mountains aligned with the opponents of secession prior to, during, and, unlike much of the state, even after the conflict ended. Evidence also suggests that the alignment resulted from a rich Whig political tradition, a strong civic connection to the founding, and a deep national pride connected to military service in America's previous conflicts. Also important for the residents of Southeastern Kentucky were issues related to class. Many of the mountainous citizens cast a suspicious eye towards the central Kentucky slavocracy_including a mistrust of the Bourbon aristocracy types found in Lexington. These traditions and outlooks combined to form a strong self-view and shaped the opinions of residents on the eve of civil war, who in large number, were reluctant to give 
up on the idea of a United States Republic. Those factors deserve more weight than earlier historians and their historiography have allowed. During the critical year of 1861, the call to arms and political activity in southeastern Kentucky reflected a deep national spirit that aided the Union.

Events following the November 1860 election of Abraham Lincoln revealed varying degrees of uncertainty about the future for the state governments and the people below the Mason-Dixon Line. In the cotton producing states of the Lower South, the decision to secede came swiftly after Lincoln's electoral victory. Beginning in December 1860, South Carolina led an initial wave of secession that resulted in seven states leaving the Union before Lincoln's March 1861 inauguration. The remaining eight states with slavery, including Kentucky, practiced a more measured caution towards choosing disunion in the immediate aftermath of the Republican Party victory. The Upper South, comprised of Virginia, Tennessee, North Carolina, and Arkansas, abandoned the Union after assessing the federal reaction to the April 12 events at Fort Sumter, Charleston, South Carolina. By the summer of 1861, eleven states claimed to have left the Union for the Confederacy and it appeared that more might follow. Missouri, Delaware, Maryland, and Kentucky earned the label "Border States" as a result of their proximity to the free North while possessing slavery within their borders. The historical grouping of the states suggests a neat geographic and chronological break, south to north, for state governments dissatisfied at the prospects of a new Republican administration and its stated position to halt the spread of slavery westward. However, the political reality within Kentucky leading up to, and during, the Civil War was much more complex than textbooks present. For citizens of Kentucky, news of regiments on the move struck a deep chord of concern 
among its population and the path of choosing a side in the Civil War proved to become one of the most precarious in the nation. The state's demographic mix from its short history complicated the path to the Union North or the Confederate South.

In 1792, when eighteenth century Kentucky leaders secured legislation from Virginia for separation, Kentucky became the fifteenth state in the Union and the second to form after the ratification of the United States Constitution. Kentucky attracted most of its migrants from Virginia, Pennsylvania, and North Carolina in the sixty years between statehood and the Civil War. ${ }^{71}$ A diverse mix of ideas, experiences, and backgrounds flowed into the Commonwealth. Northerners, a few generations removed from living near a burgeoning slave economy, and southerners, already acclimated to the "peculiar institution," combined to form a unique culture within the young state's population. Early efforts to eliminate slavery in Kentucky proved unsuccessful for those opposed to the institution and most slaveholders settled in the central and western portions of the state - areas with a topography and soil more conducive to the use of slave labor.

At its 1792 inception, Kentucky had three counties_-Lincoln, Jefferson, and Fayette. It did not take long for local communities to carve out more counties from within the boundaries of these original three to bring local government closer to the residents scattered across the Commonwealth. Clay County became one of the earliest and most influential counties in the southeastern portion of Kentucky. Formed in 1806 and named after Green Clay, Clay County's original county lines included the future

${ }^{71}$ James C. Klotter and Lowell Harrison, A New History of Kentucky (Lexington: University Press, 1997), 49. 
county seats of Leslie, Perry, Knott, Owsley, and Lee Counties and portions of future Jackson, Laurel, Bell, Harlan, and Breathitt counties. Like most of antebellum Kentucky, Clay County showed enthusiastic support for Whig policies in its first half-century of political existence and cast admiration toward the first cousin (Henry Clay) of the county's namesake. Sociologists Dwight Billings and Kathleen Blee wrote:

Clay County's unswerving loyalty from 1828 to 1851 to Henry Clay's Whig Party, a party committed to "enhancing the profitability of property," suggests that is was no different. The strength of its voters' commitment to the principles of Whiggery placed it among Bluegrass and other southeastern counties in the "Whig Gibraltar," while the actions of its county court prior to the emergence of political parties suggest that Clay County leaders aggressively pursued policies associated with modernization and economic development. ${ }^{72}$

Henry Clay's popularity stemmed from his political ability to capture the frontier attitudes connected to Kentucky's egalitarian spirit and the rise of a professional class. In this environment, Clay rose as a leading spokesman in what state historian James Klotter identified as "a hybrid society, with roots planted in both America's past and in its future." 73

The political and economic activity in areas south of Lexington drew interest from a national level. Henry Clay's American System sought to advance western frontiersmen with a system of tariffs, banking, and internal improvements. The system appealed to most Kentuckians and many of the residents in these underdeveloped areas believed the measures were sorely needed. However, when the Whig Party's influence faded in the 1850s following Clay's death, few Kentuckians sought the move to the new Republican

\footnotetext{
${ }^{72}$ Dwight B. Billings and Kathleen M. Blee, The Road to Poverty: The Making of Wealth and Hardship in Appalachia (Cambridge: Cambridge University Press, 2000), 108-109.

${ }^{73}$ James C. Klotter, Henry Clay: The Man Who Would Be President (Oxford: Oxford University Press, 2018), 19.
} 
Party as an alternative. As a recent convert to the Republican Party in 1858,

Pennsylvania Senator Simon Cameron wrote about Kentuckians south of Lexington and concluded that "these poor white men of the South, who are our brothers, and our natural allies, must be taught ... we are battling for their rights."74 As far back as the 1840 s, prominent northern politicians cast a hopeful eye toward Kentuckian Cassius Clay's efforts to cultivate antislavery sentiments in the slave state and northerners supported his efforts in hope that his followers signaled a "harbinger" of hidden southern sentiment. ${ }^{75}$ Throughout the Antebellum Era, more mountainous areas of Kentucky established new counties as the history of the state progressed. But even if these localities split geographically from parent counties, familial ties and traditions caused them to resemble one another in culture, economy, political structure, and outlook.

The demographic complexity affected Kentucky and debates over Union or secession provided a contrast in experience for residents in different regions of the state. Arguments reached a fevered pitch after the violent encounter at Fort Sumter on April 12, 1861. Accused of harboring deep feelings for the southern cause, Governor Beriah Magoffin maneuvered to keep Kentucky "neutral” in the aftermath. ${ }^{76}$ The political tugof-war between Kentucky's more pro-Union General Assembly and Governor Magoffin's Confederate sympathies produced a series of ill-conceived attempts to

${ }^{74}$ Eric Foner, Free Soil Free Labor Free Men: The Ideology of the Republican Party Before the Civil War (New York: Oxford University Press, 1970), 120.

${ }^{75}$ Ibid., 120-121.

${ }^{76}$ For more on this period see Robert William Goebel's, "Casualty of War: The Governorship of Beriah Magoffin, 1859-1862," (2005), Electronic Theses and Dissertations University of Louisville, Paper 506, and Jacob F Lee's, "The Union as it was and the Constitution as it is": Unionism and Emancipation in Civil War Era Kentucky," (2007), Electronic Theses and Dissertations University of Louisville, Paper 807. 
remove Kentucky from making a choice of joining either the Union or the Confederacy. ${ }^{77}$ On May 16, the House of Representatives voted 69-29 for a resolution of strict neutrality. The Senate passed similar legislation and Governor Magoffin declared Kentucky's neutrality in the days that followed. ${ }^{78}$ The legislative effort to stay out of the conflict, however, made little difference to recruiters who sought soldiers from the state willing to fight as agents from the Confederacy and Union made efforts to recruit soldiers from across all parts of the state.

During the days of the state government's debate that pronounced Kentucky "neutral," William "Bull” Nelson visited President Abraham Lincoln in Washington, D.C., to request 5,000 arms to outfit Unionist Kentuckians. ${ }^{79}$ Nelson developed a distribution scheme for the rifles that involved eight prominent Kentuckians, including Lincoln friend Joshua F. Speed, to help carry out the plan. On July 1, federal authorities directed Nelson to establish a camp in the southeastern part of the state and to collect three regiments of Union-minded Kentuckians. National, as well as state, politicians identified the northern Ohio River region and the Appalachian area as possessing the most pro-Union citizens. Southern historian E. Merton Coulter added, "This was a bold and daring attempt to capitalize on the strong Union sentiment that existed in the eastern regions of Kentucky and Tennessee, and to lay hold on the strategic passes from

77 Thomas C. Mackey, "Not a Pariah, but a Keystone: Kentucky and Secession," in Sister States, Enemy States: The Civil War in Kentucky and Tennessee, editors Kent T. Dollar, Larry H. Whiteaker, and W. Calvin Dickinson, (Lexington: The University Press of Kentucky, 2009), 25-45.

${ }^{78}$ Lowell H. Harrison, The Civil War in Kentucky (Lexington: University Press of Kentucky, 1975), 9.

${ }^{79}$ E. Merton Coulter, The Civil War and Readjustment in Kentucky (Chapel Hill: University of North Carolina Press, 1926; reprint, (Gloucester, Mass.: Peter Smith, 1966), 89. 
Tennessee and the Southwest into Virginia." ${ }^{80}$ Most of the original 5000 guns federals allocated for Kentucky went to the northern and central portion of the state, but the southernmost destination, which became Camp Dick Robinson, received a shipment that helped outfit some of the southeastern Kentuckians who volunteered to fight for the Union. ${ }^{81}$ The weapons that arrived received the name of "Lincoln Guns" and constituted a source of criticism for Confederate supporters inside and outside of Kentucky.

Newspapers in the northern and more populated parts of the state added to the excitement of southern Kentuckians joining the ranks of the Union. The Louisville Daily Journal featured stories connected to the fears of a Confederate invasion. On August 12 the paper stated:

Kentucky Invaded! Arouse, Union Men! We have just received the information that a force of between two and three thousand disunion troops have marched into Kentucky through the Cumberland Gap. The Union men in that vicinity immediately sent runners to Owsley, Jackson, and Estill, and other counties in the region. The Union men are rapidly gathering in those counties and arming with rifles, shotguns, etc. ${ }^{82}$

Yet, a coordinated invasion of any real size would not occur for another month. Fearful that the pro-Union headlines might result in accusations of aggression, the paper sought to clarify the following day with the reassurance "if the Union troops are mustering in the counties of Kentucky near the Cumberland Gap, it is to defend Kentucky soil from invasion and not to invade the soil of Tennessee." ${ }^{13}$ Nonetheless, uneasy Kentuckians in

${ }^{80}$ Ibid., 102.

${ }^{81}$ Ibid.

${ }^{82}$ The Louisville Daily Journal, August 12, 1861. as found in Kentucky Soldiers and Their Regiments in the Civil War: Abstracted from the Pages of Contemporary Kentucky Newspapers, Vol. 1, 1861, edited by Stephen L. Wright (Utica: McDowell Publications, 2009), 89.

${ }^{83}$ The Louisville Daily Journal, August 13, 1861. as found in Kentucky Soldiers and Their Regiments in the Civil War: Abstracted from the Pages of Contemporary Kentucky 
the Southeast poured into Camp Dick Robinson in answer of the call for defense. On September 9, the Louisville Daily Journal reported that "Camp Dick Robinson is swelling at a rate of two hundred per day and already extends a mile and a half down the road." ${ }^{84}$ Local community leaders, not newspapers, likely did more getting men to the camp for protection of the state.

Theophilus Tolman Garrard was one of the earliest and most influential leaders who gathered Union troops in Southeast Kentucky. Garrard formed deep connections to Clay County and was from a line of early prominent Kentuckians. Grandson of Kentucky's second governor James Garrard, Garrard served as a main point of contact for General Nelson into the populations of Southeastern Kentucky. Garrard's father, Colonel Daniel Garrard, became famous for his leadership in marching Clay County troops into Canada at the onset of the War of 1812. Theophilus Garrard, referred to at T.T., already had a history of getting southeastern Kentuckians to volunteer for a national cause dating back to the conflict with Mexico. In April 1847, Garrard recruited and collected over forty men in Manchester and Booneville to join Company E of the $16^{\text {th }}$ Infantry for the Mexican-American War. ${ }^{85}$ Garrard served as a Captain in the Mexican-American War and rose to the rank of Colonel. Over a decade later, the federal government entrusted Garrard again and, in the summer of 1861, selected him to raise a regiment of Union volunteers for Camp Dick Robinson. Nelson’s request of T.T. Garrard violated the

Newspapers, Vol. 1, 1861, edited by Stephen L. Wright (Utica: McDowell Publications, 2009), 89.

${ }^{84}$ The Louisville Daily Journal, September 9, 1861.

${ }^{85}$ Papers related to T. T. Garrard's service in the Mexican-American War are found in both the Kentucky Room at the Jackson County Library and at the Clay County Historical Society. 
state's policy of neutrality; but, both Union and Confederate leaders at the national and local levels were nervous about the invasion of troops near the Kentucky-Tennessee border. The recruitment went forward and the 3rd Kentucky Regiment of Infantry (soon renamed the $7^{\text {th }}$ ) was noted as the only regiment with a full quota of 1000 troops when, on September 22, the group mustered in at Camp Dick Robinson.

T.T. Garrard's calls for Union service went beyond just his home of Clay County and men from surrounding areas started to respond. A town in neighboring Owsley County, Sturgeon provided another important outpost for Garrard's recruitment. In 1854, the former Justice of the Peace of Clay County, William Clark, left his native county and bought a farm in Owsley County at a location named Green Hall (which was to become part of Jackson County in 1858). Once word traveled to the Clarks of Garrard's call for recruits, William's two sons, Andrew and Henry, enlisted in Company D and made their way to Camp Robinson. ${ }^{86}$ Andrew Clark rose to the title of First Captain of Company D for Garrard's $7^{\text {th }}$ regiment. Clark, who reenlisted on February 23, 1863, used his own influence for an effort like Garrard's to raise the $47^{\text {th }}$ Kentucky Mounted Infantry of which 71 Jackson Countians volunteered. Another prominent Jackson Countian, Levi Pennington, became captain of Company $\mathrm{C}$ for the $7^{\text {th }}$ Infantry (Pennington would later die at Chickasaw Bluffs in General Grant's first assault on Vicksburg.) In all, 31 Jackson Countians were part of this earliest company and their service resulted in many of the local men fighting in a variety of future campaigns.

\footnotetext{
${ }^{86}$ James L. Clark, “Clay County's Andrew Clark and the Civil War in Kentucky,” Clay County Ancestral News, (Manchester: Clay County Genealogical and Historical Society, 2003) 49.
} 
A high percentage of other Southeastern Kentuckians answered the call to volunteer as well. Historians credit Captain George M. Jackson, the editor of a Unionist newspaper in Winchester named The National Union, for raising the first Kentucky recruitment of voluntary troops for Union service. ${ }^{87}$ A central Kentuckian, Jackson organized the volunteers of his group at the Red River Iron Works in Clark and Powell Counties. The Red River Gorge area was important because it formed the boundary separating the central Kentucky Bluegrass Region and the mountains of eastern Kentucky. The site of recruitment, on the Appalachian side of Captain Jackson's native Clark County, became an ideal temporary location for receiving Union volunteers from the southeastern mountains. Afterwards, Jackson marched to Camp Robinson and wrote, "We reached Camp Dick Robinson about daylight on the morning of August $7^{\text {th }}$, where we met other volunteers, and they commenced pouring in from all points. Thus, was neutrality discarded, and the first camp established on Kentucky soil." ${ }^{\prime 8}$

Another Union Captain, T.J. Wright, recounted a positive experience in the gathering of recruits in areas of Southeast Kentucky. Wright met with fresh volunteers of the Home Guard during July in Estill County, twice a week, to drill and to maintain an organization in case of emergency. Wright observed that the men were excellent marksmen and judged that they had handled firearms since an early age. ${ }^{89}$ The group went to the southern portion of neighboring Madison Country, again where the Bluegrass and Appalachia met, and drummed up even more recruits from the mountainous region.

${ }^{87}$ A.C. Quisenberry, "Kentucky's 'Neutrality' in 1861," Register of Kentucky State Historical Society, 15 (Jan. 1917): 10-17.

${ }^{88}$ Ibid., 17.

${ }^{89}$ Wright, T.J., History of the Eighth Regiment of Kentucky Voluntary Infantry During its Three Years Campaign, (St. Joseph, MO: St. Joseph Steam Printing Company, 1880), 7. 
By September, the unit reached enough recruits to form the $\mathrm{B}, \mathrm{C}$, and $\mathrm{H}$ Companies. At Station Camp, located just a few miles from Jackson County's northeastern border, Wright's men celebrated the achievement of filling the ranks and local residents provided a feast. Wright observed that the recruits were "followed by drums and fife, appealing to the patriotism of the young men to take up arms of the best Government ever vouchsafed to man on earth." 90 On September 26, from Station Camp, Captain Wright and Captain R. Winbourn split up and made their way deeper into the mountains and arrived at a neighboring farm where potential recruits awaited in Owsley County. Wright recalled the experience:

The surrounding hills re-echoed the sound of our martial band, the music of which was not the best, but the patriotic ardor being augmented by the rumored invasion of the State by the rebels under Zollicoffer, caused men, women and children to collect from all directions, some bearing large baskets filled with provisions, all with hearts full of love for our old flag and freedom. At 10 o'clock a.m. several hundreds of eager, expectant persons had assembled..$^{91}$

When reading personal accounts from the journals or memoirs of military leaders, it is important to use other sources of evidence to make sure exaggerations and embellishments do not outweigh the trustworthiness of the source. Taken together, however, a pattern of enthusiasm emerges as recruiters made their way around the southern mountain counties.

Statistics of United States enlistment shed some light on the state's geographical pattern of service. Accurate statistics on Civil War enlistments vary and exactness is difficult, if not impossible, to obtain. Kentucky Adjutant General D. W. Lindsey

\footnotetext{
${ }^{90}$ Ibid., 8.

${ }^{91}$ Ibid., 8-9.
} 
compiled what historians believe to be one of the more trusted county-by-county lists at the end of $1864 .{ }^{92}$ In the Jackson Purchase region of the state, the seven counties classified to that area boasted a population of 64,507 based on the 1860 census and provided 650 military personnel for the Union, a rate of $1 \%$ of the population. Historians considered that area as one of the strongest for pro-Confederate activity and Lindsey's numbers back that claim. Based on the same metric, for the Eastern Pennyroyal portion of the state made up of sixteen counties ranging from just east of Bowling Green to Somerset, the population stood at 153,443 with enlistments at 10,766 or $7 \%$. For the Southern Eastern Highlands, the population was 80,360 with a total enlistment of 6,853 or 8.5\%. Narrowing down to just Jackson, Clay, Owsley, and Estill Counties, the population of those four adjoining counties stood at 21,960 in 1860 and they combined to provide 2681 soldiers or $12 \%$. Three of Kentucky's larger counties, all north of the region, offer an interesting contrast as Jefferson $(89,404$ population, 6,578 enlistments or $7 \%)$, Fayette (22,599 population, 703 enlistments or 3\%), and Madison (17,207 population, 539 enlistments or 3\%) all provide numbers far below their southeastern counterparts. ${ }^{93}$ Some of the percental discrepancy of military enlistment lies in the small portion of slaves in the populations of the smaller southeastern counties. But even with slaves removed from the numbers, the southeastern rate of participation still outweighs the contributions of the areas listed here. That also brings into focus an interesting historiographical debate as many modern scholars analyze Kentucky’s Unionist activity as a mix of interests that included a large portion who fought to protect slavery within a

92 Kenneth H. Williams and James Russell Harris, "Kentucky in 1860: A Statistical Overview," The Register of the Kentucky Historical Society, 103 (Autumn 2005): 757. 93 Ibid., 744-750. 
constitutional Union. Motivations to enlist varied across the state and records suggest prominent men in the central Bluegrass and western regions of the state fought to protect slavery within a constitutional union. ${ }^{94}$ The protection of slavery did little to motivate the men of the Southern Eastern Highlands.

1861 political activity revealed another aspect of Kentucky's allegiances as voting at the polls matched the Union spirit of the volunteering men who made their way to camps. The state's bicameral legislature grew in pro-Union sentiment in the summer elections of August. After the vote for the State House of Representatives, pro-Union men outnumbered confederate sympathizers at a count of 76-24. In the Senate the number stood at 27-11. Just how much this vote changed the dynamic of the Kentucky's state legislature is hard to measure, but historians agree that these gains produced sizeable majorities in each chamber of the General Assembly. Billed as a referendum on secession, the statewide election that followed the wave of southern secession allowed Kentucky voters to express their position on the issue. Moreover, the results meant that the legislature held enough votes to override any of Magoffin's vetoes and resulted in the power to impeach the governor if he tried to aid or shield the Confederacy. ${ }^{95}$

Prior to the General Assembly election, Kentucky held an election for federal representatives on June 22 due to President Lincoln's call for a special session. In the ten seats up for grabs, nine Unionist candidates won. Perhaps more interesting is the gaps that exist deeper inside the raw numerical results. The State's Rights candidate won the

\footnotetext{
${ }^{94}$ For more on the motivation of Central Kentucky volunteers see Patrick A. Lewis's, For Slavery and Union: Benjamin Buckner and Kentucky Loyalties in the Civil War (Lexington: University Press of Kentucky, 2015).

95 James C. Klotter, "Kentucky, the Civil War, and the Spirit of Henry Clay," The Register of the Kentucky Historical Society, 110 (Summer/Autumn 2012): 259.
} 
first district, the far western end of Kentucky, and the victory marked the only race the Confederates could claim. The Unionist candidate took the second and third districts, which both were in the next two western-most portions of the state, by an average margin of three to one. In the fourth and fifth districts, located in the central portion of the state, the Unionist candidate won by a rate of four to one. In the seventh, eighth, ninth, and tenth districts, which included the northern portion of the state and its most important cities, the Unionist candidate won between $60 \%$ and $80 \%$ of the vote in each. The final election tallies of 1861 suggest that Kentucky objected to secession and the Confederacy. In the sixth district, which included the Southeastern Appalachian counties, the Unionist candidate won 8,181 of the 8,410 votes cast - a total of $97 \% .{ }^{96}$ These numbers in total, and the absence of enough serious secessionist sentiment to even field a viable candidate in the sixth district, reveal that Confederate support lagged Unionist sentiment throughout most of the state in 1861. In the southeastern mountains, however, the Confederate spirit not only lagged — it was nearly non-existent.

Confederate military strategy targeted Kentucky in the late summer of 1861 around the same time that the political picture came into focus. Events in the far western portion of the state occurred first and the actions prompted decisions from the new General Assembly. By September 3, Confederate General Leonidas Polk's troops occupied the bluff above Columbus Kentucky near the Mississippi River. On September 10, Jefferson Davis placed Albert Sidney Johnston in command of a large portion of Confederate operations in the western theatre of the war. Leaving Richmond Virginia

\footnotetext{
96 Thomas Speed, The Union Cause in Kentucky: 1860-1865, (New York: The Knickerbocker Press, 1907), 88-89.
} 
with his new appointment, Johnston headed to Nashville to conduct operations from Central Tennessee. General Johnston arrived and signaled a more aggressive approach as one of his first decisions was to appoint Simon Bolivar Buckner as brigadier general and to order him to occupy Bowling Green. ${ }^{97}$ But prior to reaching Nashville, Johnston stopped in Knoxville to confer with Confederate General Felix Kirk Zollicoffer. Zollicoffer, whose only military experience prior to the Civil War was as a volunteer lieutenant for Andrew Jackson in the 1835 Second Seminole War, received the command of East Tennessee on the recommendation of Confederate General Polk prior to Johnston's appointment. ${ }^{98}$ Like Buckner and Polk, Zollicoffer prepared for a Confederate invasion into Kentucky.

The Confederate military plans carried out in September 1861 did much to push the state of Kentucky further into Union arms. As Polk moved Confederate Brigadier General Gideon Pillow into Colombia at the far western end of the state, and Buckner eyed Bowling Green near the southern center, Zollicoffer gathered soldiers around Cumberland Gap for a northern advance from the southeast on the old Wilderness Road toward Lexington. The military operations on each southern corner of the state occurred within a week of one another. However, the move into the area north of the Cumberland Gap presented logistical and environmental challenges for the Confederates unlike the other operations. On September 10, 1861 Zollicoffer relayed the difficulty to Samuel

${ }^{97}$ Harrison, The Civil War in Kentucky, 16.

${ }^{98}$ For more on Felix Zollicoffer see Brian McKnight's "Reconsidering Felix Zollicoffer: The Influence of Weather and Terrain in the Rise and Fall of a Military Commander in Appalachia," in Kent T. Dollar, Larry H. Whiteaker, and W. Calvin Dickinson ed. Border Wars: The Civil War in Tennessee and Kentucky (Kent: Kent State University Press, 2015), 147-169 and Raymond E. Myers's The Zollie Tree (Louisville: The Filson Club Press, 1964). 
Cooper at the War Department calling the country between Cumberland Gap and Camp Dick Robinson "poor and hostile." 99 The soldiers at Camp Dick Robinson represented the most important line of defense between an invasion from the southeast and Kentucky's central region of cities, navigable rivers, and other resources. Union military leaders assigned Colonel T.T. Garrard's regiment to protect the Rockcastle Ford on the Wilderness Road, south of Camp Robinson. ${ }^{100}$ Colonel Garrard's company, undersupplied and underfed, received little training before being moved to the strategic position. During the time of preparation and guard, Garrard communicated to Brigadier General George H. Thomas who replaced General Nelson in early September as commander of Camp Dick Robinson. General Thomas, in turn, wrote General William T. Sherman who oversaw the countering of Buckner's move into the south-central part of the state.

The Confederate offensive into the far western portion of the state proved a poorly planned strategy and Pillow's occupation of Columbus provided enough immediate concern for the General Kentucky Assembly to make the decision to end neutrality. Under command from General John C. Frémont, General Ulysses S. Grant moved into Paducah to counter the Confederate advance. Confederate leaders decried the actions of the Federals with complaints that Camp Dick Robinson, the shipment of guns, and covert actions into Kentucky's Mississippi River towns were the first violation of the

${ }^{99}$ U.S. War Department, The War of the Rebellion: A Compilation of the Official Records of the Union and Confederate Armies 128 vols. (Washington: U.S. Government Printing Office, 1880-1901), Series I, Vol. 4, 199.

${ }^{100}$ Thomas D. Clark, A History of Laurel County: An Account of the Emergence of a Frontier Kentucky Appalachian Community (London: Laurel County Historical Society, 1989), 203. 
state's neutrality policy. The political criticism from the Confederates on who violated neutrality first, however, did little to influence Kentucky's General Assembly. For Kentucky's members of the House and Senate, the Confederate earlier move into Columbus militarily justified the Union's counter into Paducah—a place of more strategic value. As historian Steven Woodworth noted:

The irony lay in the fact that as long as the Federals held Paducah, Columbus, which could thus be easily outflanked, was of no military value whatsoever to the Confederacy. The state of affairs that Polk saw as the confirmation of the correctness of his decision was in fact the very thing that made his action futile. This fact was seen at once by an intelligent soldier and pro-Southern Kentuckian, Simon Bolivar Buckner, and pointed out within a few days in a letter to Richmond. ${ }^{101}$

The town acted as a trap, and the political repercussions damaged the Confederate's broader overall Kentucky strategy.

In September 1861, the General Assembly flexed some of its new political strength gained from the August elections and ended the policy of neutrality only four months after passing the measure. On September 18, following the first Confederate invasions into the state, the assembly passed a series of resolutions that favored the Union. The statement started with a strong rebuke of Confederate actions and proclaimed, "Whereas, Kentucky has been invaded by the forces of the so-called Confederate States . . . be it resolved by the General Assembly of the Commonwealth of Kentucky, that the invaders must be expelled ...."102 The second resolution elevated

${ }^{101}$ Steven E. Woodworth, "The Indeterminate Quantities: Jefferson Davis, Leonidas Polk, and the End of Kentucky Neutrality, September 1861," Civil War History, Vol. 38, No. 4, Dec. 1992 (Kent State University Press), 296.

102 "Journal of the House of Representatives of the Commonwealth of Kentucky, September 2, 1861 - March 3, 1863, Volume One" (1861), Kentucky, General Assembly, House of Representatives., Journals of the General Assembly of the Commonwealth of Kentucky, 153. 
General Robert Anderson, federal hero of Fort Sumter and native Kentuckian, to "take instant command, with authority and power of this Commonwealth to call out a volunteer force in Kentucky for the purpose of repelling the invaders from our soil." ${ }^{\prime 103}$ The resolutions ended with a plea "that the patriotism of every Kentuckian is invoked, and is confidently relied upon to give active aid in the defense of the Commonwealth." Four of the affirmative votes on all five of the resolutions came from James W. Anderson representing Knox County, Albert A. Curtis representing Estill and Jackson Counties, E.B. Bacheller representing Laurel and Rockcastle Counties, and Alex T. White representing Clay and Owsley Counties. Two days after the vote, Governor Beriah Magoffin responded that he did not support the language of the resolution and showed specific concern about the appointment of General Anderson. Magoffin stated:

I object to these resolutions, secondly, because they needlessly invite a military officer in the Federal service to take command of the department of the Cumberland, embracing Kentucky, who will not be bound by the expressions of your resolutions, but will be required to obey the orders of the Federal government, whether they be consistent with your resolution or not, and whose powers will not be limited by any acts of the Legislature. ${ }^{104}$

The governor's stern warning about the implications of empowering federal authorities did not discourage the General Assembly and the body passed the measure over Magoffin's objections. The vote totals in the House hovered around a three-quarter proUnion and one-quarter state's rights split. The pro-Union caucus neutralized any of Magoffin's actions to position Kentucky as either neutral or pro-Confederate. Even though many Kentuckians wanted to keep the Commonwealth from becoming a

${ }^{103}$ Ibid.

${ }^{104}$ Ibid. 176. 
battleground, the language and political posture from the summer of 1861 suggest that a Union path emerged.

Zollicoffer found conditions in East Tennessee difficult as that mountainous portion of the state held a sizable pro-Union presence of its own. The area resembled Southeastern Kentucky in environment and temperament. A large portion of these Southern Unionists in East Tennessee traced familial lines to the North and many had relatives in Kentucky. At a higher rate than anywhere else in the Confederate South, these residents developed a distrust of the slave power and viewed the Confederacy as an aristocratic regime at odds with the common folk of those areas. ${ }^{105}$ Like Southeastern Kentucky, a leftover Whig residue was one of the strengths in Eastern Tennessee that obstructed the earliest secessionist effort. William G. Brownlow owned a popular paper called Brownlow's Knoxville Whig that boasted a circulation of twelve thousand-the largest in the state. ${ }^{106}$ Historian Daniel Crofts adds:

In November and December 1860 Brownlow and the Union Whigs from Knoxville undertook to block the 'wild stampede toward secession.' They stirred the 'friends of the Union' from the outlying countryside. . . At a memorable five-hour public meeting on December 8, in a courthouse building so jammed that many people could not fit inside, Brownlow and the unconditional Unionists adopted resolutions denouncing secession. ${ }^{107}$

Considered for a Unionist candidate for governor, Brownlow established a strong Whig following in the eastern part of the state in the antebellum years. Brownlow's reputation and influence must have made an impact on the military loyalties of the area. Historians

\footnotetext{
105 Stephen V. Ash, When the Yankees Came: Conflict and Chaos in the Occupied South, 1861-1865, (Chapel Hill: The University of North Carolina Press, 1995) 109-110.

${ }^{106}$ Daniel W. Crofts, Reluctant Confederates: Upper South Unionists in the Secession Crisis (Chapel Hill: The University of North Carolina Press, 1989), 22.

${ }^{107}$ Ibid., 24-25.
} 
have estimated that up to 100,000 white southerners from seceded states fought for the Union, with 42,000 of those men coming from East Tennessee. ${ }^{108}$

In Southeastern Kentucky, the movement of both Union and Confederates did not match the quick unfolding of events of Grant and Pillow near the Mississippi River. Instead, the environment and population interrupted and slowed the pace of Confederate advance. One soldier remarked that some of the troops nearly walked off bluffs due to fatigue and another observed "long haired men with long squirrel rifles ever ready to shoot a Rebel when opportunity presented." 109 Twenty miles north of the Cumberland Gap, the small town of Barbourville became the first significant encounter of resistance for the invading Confederates on their way up the Wilderness Road. On September 18, Zollicoffer ordered an advance of eight-hundred troops where they were met with threehundred Home Guard Kentuckians located at Camp Andrew Johnson. ${ }^{110}$ The clash resulted in a number of dead soldiers, the destruction of the camp, and a victory for Zollicoffer's men. Although small in scale, the event drew national, state, and local attention. General Robert Anderson telegraphed Abraham Lincoln September 16 with the warning "We have received positive information that the Tennesseans are invading Kentucky through the Cumberland Gap. We can get plenty of men if we can obtain arms

\footnotetext{
${ }^{108}$ Kenneth W. Noe, "Battle Against the Traitors: Unionist Middle Tennesseans in the Ninth Kentucky Infantry and What They Fought For," Sister States, Enemy States: The Civil War in Kentucky and Tennessee ed. Kent T. Dollar, Larry H. Whiteaker, and W. Calvin Dickinson, (Lexington: University Press of Kentucky, 2009), 123. ${ }^{109}$ Kenneth Hafendorfer, The Battle of Wildcat Mountain, (Louisville: KH Press, 2003), 29.

${ }^{110}$ Brian McKnight, Contested Borderland: The Civil War in Appalachian Kentucky and Virginia (Lexington: The University Press of Kentucky, 2006), 37.
} 
for them. This is of vital importance."111 Lincoln responded, "From what you telegraph today, I think you better take active command in Kentucky at once. War Department will telegraph you about arms tomorrow." 112 Once Zollicoffer established a presence in Barbourville, the Goose Creek Salt Works in Clay County represented a cache of resources and became the first major Confederate target in Southeast Kentucky. A week after arriving in Barbourville, Zollicoffer alerted Albert Sidney Johnston that he would make a move on the Manchester location. ${ }^{113}$ The raid proved to be a material success. Zollicoffer's troops collected 8,000 cartridges, 3 kegs of powder, 6 barrels of salt, 3 horses, 25 pairs of shoes, and several guns. Beyond material gain, the general wanted to convert the population to his side. Historian Brian McKnight assessed:

Although Zollicoffer's raid on the saltworks was successful, he remained doubtful about the support of the mountaineers. During the raid on the works, several of Zollicoffer's men took time to harass the population. While they did little more than destroy haystacks and burn rails, their inadvisable actions weakened the already limited Confederate support in the region. ${ }^{114}$

The Louisville Daily Journal reported later that “Zollicoffer's robbers have been running riot in Knox, Whitley, Laurel, Clay and Rockcastle Counties." ${ }^{115}$ T.T. Garrard relayed news of the events in Manchester to General Thomas at Camp Dick Robinson.

111 "Letter to Robert Anderson, September 16, 1861," Abraham Lincoln and Roy P. Basler, The Collected Works of Abraham Lincoln: Volume IV 1860-61 (New Brunswick, N.J.: Rutgers University Press, 1953), 524.

${ }^{112}$ Ibid.

${ }^{113}$ Zollicoffer to Lieutenant Colonel Mackall, 24 September 1861, Official Records IV, 199.

${ }^{114}$ McKnight, Contested Borderlands, 39.

${ }^{115}$ Louisville Daily Journal, October 16, 1861, as found in Kentucky Soldiers and Their Regiments in the Civil War: Abstracted From the Pages of Contemporary Kentucky Newspapers, Vol. 1, 1861, edited by Stephen L. Wright (Utica: McDowell Publications, 2009), 89. 
On September 22, only a few days after the events in Barbourville and Manchester, President Lincoln penned his most famous statement about the importance of keeping Kentucky in the Union. Lincoln's message to Orville H. Browning, another Kentucky-born Illinois politician, revealed how important that the sixteenth President viewed the Bluegrass State as he lamented, "to lose Kentucky is nearly the same as to lose the whole game. Kentucky gone, we cannot hold Missouri, nor, as I think, Maryland. These all against us, and the job on our hands is too large for us. We would as well consent to the separation at once, including the surrender of this capitol."116 The context of Lincoln's concern related to Union General Frémont's heavy-handed actions and confiscations in Missouri-an approach that alarmed the slaveholding populations of the Border States. As the picture in the western and central portion of the state raised fears of Confederate political momentum, Lincoln turned toward gains made in the General Assembly and the situation in the eastern portion of the state to balance his negative prognostications. The letter to Browning, and the fears of "losing the whole game" if Kentucky aligned with the Confederacy, is often quoted and captures the significance of the President's birth state. On October 1, two weeks later, Lincoln issued a "Memorandum for a Plan of Campaign." The message opened with thoughts on securing the area around Cumberland Gap. Lincoln assessed the situation with more detail with a careful eye on Southeastern Kentucky:

That point is now guarded against up by Zollicoffer, with 6000 or 8000 , rebels at Barboursville, Kentucky, say twenty-five miles from the Gap towards Lexington.

We have a force of 5000 or 6000, under General Thomas, at Camp Dick Robinson, about twenty-five miles from Lexington, and seventy-five from

116 “To Orville H. Browning, September 22, 1861," The Collected Works IV, 1860-61, 532. 
Zollicoffer's camp on the road between the two, which is not a Railroad, anywhere between Lexington and the point to be seized - and along the whole length of which the Union sentiment among the people largely predominates. ${ }^{117}$

Further north up the Wilderness Road from Zollicoffer's position in Barbourville, Colonel Garrard guarded London with local volunteers, and the position developed into an important piece for the Union's long-range plan and, more importantly, the immediate defense of Eastern Kentucky.

The $7^{\text {th }}$ Kentucky Infantry Regiment moved south from Camp Dick Robinson, to a position near the city of London, and the troops settled at Camp Wildcat near the Rockcastle River. As Zollicoffer's force of 5,000 approached north from Barbourville, Garrard's group of 900 stood as the main obstacle. Garrard reached out to General Thomas for more troops and provisions in desperation. Union reinforcements arrived on October 20 when Hungarian-born Brigadier General Albin Schoepf took command. The next day a battle involving over 12,000 troops led to a Union victory and Zollicoffer's withdrawal back to the Cumberland ford. Casualties were low, but the defeat marked a major disruption and setback to Confederate strategy. In the weeks that followed, many of the Tennessee Unionists wanted to seize the opportunity to push south and to liberate eastern Tennessee. Instead, Brigadier General William T. Sherman ordered General Schoepf to move from Somerset to central Kentucky in something frustrated Federal troops despairingly called the "Wildcat Stampede."118 General Thomas convinced Sherman that the position in southern Kentucky needed Schoepf more and the general

117 "Memorandum for a Plan of Campaign, October 1, 1861" The Collected Works IV, 1860-61, 544.

${ }^{118}$ Stuart W. Sanders, The Battle of Mill Springs, (Charleston: The History Press, 2013), 20-23. 
was relocated back to Somerset. Confederate leadership eyed a western shift for a follow-up Kentucky invasion as Johnston and Zollicoffer decided for a push toward the Cumberland River.

Zollicoffer's October attack and retreat stands as an important moment in 1861 for the commonwealth of Kentucky — and the nation. The federal response and Union leadership averted disaster in southeastern Kentucky. Garrard's unit of local men held the position and faced certain defeat. But the bigger picture was that it symbolized a capstone of unwavering support from a people willing to defend their home and country. The recorded experiences of recruitment officials leading up to the engagement, alongside the percentage of Southeast Kentuckians who served in the early ranks for the federal cause, provide documented evidence of strong Union support. Voting patterns in state and national congressional elections revealed a political leaning that matched the military service. Northern political leaders around the country, including President Abraham Lincoln, spoke of the area with hope and a confidence that the people were on their side. Headlines from partisan newspapers and even reflections from Confederate Generals seemed either eager to expose the alliance of these mountainous residents or to concede the prospects of changing their minds. Lost Cause historians like E. Merton Coulter have minimized or ignored the buffer that these citizens provided for the Union. More recent scholars continue to attribute "mountain unionism" to the absence of a slave economy. Like all areas, this region produced Confederates, proponents for slavery, and citizens who wanted to protect the institution from within a constitutional union. But the overwhelming statistical evidence, partnered with the social history of the area, disputes that people of Southeastern Kentucky fought for any reason other than for what the 
traditions and customs of their culture directed them. While the geography of the region and the expensive cost of slaves did prevent the rise of a plantation society in Southeastern Kentucky, deep moral and social viewpoints combined to develop a culture that attracted settlers opposed to slavery to the area during the Antebellum Era. Those negative attitudes toward slavery made a difference in the build up to war and the earliest stages of the war. As the war progressed, Confederate and guerilla attacks on the area further hardened opinions of Appalachian citizens toward their southern neighbors.

Southeastern Kentuckians also held and displayed a pride in the service of preserving the Union when many others around the state either bolted for the Confederacy, started to develop southern sympathies, or simply fought for state preservation. Combined, these characteristics of the pro-Union sentiment in the region present a complex picture that may help uncover multiple causes related to Kentucky's deepest pocket of loyalty to the Union. Moreover, the political stance and military contributions of Southeast Kentuckians proved valuable to the preservation of the Union. 


\section{CHAPTER THREE}

\section{"THEY ARE HAVING A STAMPEDE IN KENTUCKY, LOOK TO IT": CIVIL WAR AND SOUTHEASTERN KENTUCKY IN 1862}

The Civil War shook Kentucky in 1862 more than any other year of the conflict. While the state experienced skirmishes, raids, and other war activity throughout the entire period of the national crisis, the size and scope of military focus toward Kentucky during 1862 surpassed all other years of the Civil War. Kentuckians expressed concerns during the presidential election of 1860 about the state becoming the front-lines if war broke out. In 1862, those fears manifested into a harsh reality during the second year of fighting. A back and forth for control of the state between pro-Confederate Governor Magoffin and the pro-Union General Assembly offered positive signals to both sides in the earliest stages of the war. As a result, this waffling caused Union and Confederate leadership to remain cautious in their approach to Kentucky's loyalty. After the initial 1861 Confederate invasion into the state failed, and a Union path emerged for the Commonwealth, more aggressive military objectives replaced political strategy. For Southeastern Kentuckians, the shift in direction brought violence and large foraging armies into their communities. The residents of the area maintained a strong loyalty to the Union Army and many of the men who volunteered for the Union cause found themselves at the center of important battles - both near home and far away. Within the state, engagements at Mill Springs, Big Hill, Richmond, and Perryville produced mixed results; yet, by the year's end, the Confederates abandoned any real hope to seize 
Kentucky. The Union soldiers from Southeastern Kentucky, as well as larger portions of the local population, provided resistance and endured great hardships throughout 1862 to stop the Confederate military invasion and political takeover.

I.

After the October 1861 Battle of Wildcat Mountain and the retreat to Tennessee that followed, Confederate leadership planned to move General Felix Zollicoffer who was just outside of Somerset, in another effort to invade central Kentucky. Instead of following the original path that held close to the Wilderness Road, the new Confederate position shifted the strategy of attack over forty miles westward into Pulaski County. That location provided access to the Cumberland River and the coal needed to supply Nashville. ${ }^{119}$ In charge of Kentucky operations for the Union, Brigadier General William T. Sherman believed the new Confederate movements posed a direct threat to the key cities of Louisville and Lexington. No decision to march south after the Battle of Wildcat Mountain to liberate eastern Tennessee, as many of the troops within the Union ranks wanted, occurred. Instead, Sherman reacted to the new southern positioning of the Confederates and pulled General Albin Schoepf back to central Kentucky to defend the Bluegrass region - a movement that signaled the priority of the Union military and one to the disappointment of the Tennessee Unionists. A series of additional changes followed in November and December 1861. Union General George Thomas advocated and won a

${ }^{119}$ Stuart W. Sanders, The Battle of Mill Springs (Charleston: The History Press, 2013), 20-22. 
decision that returned General Schoepf back to the Somerset area in the late fall of 1861. In addition, federal leadership replaced a worrisome Sherman with Don Carlos Buell as the new brigadier general in charge of Kentucky. ${ }^{120}$ Sherman's hasty movements and his claims that hundreds of thousands of troops were needed to defend Kentucky led to the replacement. $^{121}$

General Buell faced an issue deemed important to the Lincoln administration with the situation in eastern Tennessee during the early stages of his military appointment. The concern was not a new development as advocates for an eastern Tennessee invasion emerged in the earliest stages of the war. In September 1861 during the initial three-part Confederate invasion into Kentucky, a Unionist congressman from Tennessee, Horace Maynard, advised President Abraham Lincoln about the dire situation in his home state. Elected to the United States House of Representatives prior to Tennessee's secessionist vote, Maynard came from a district that shared a political outlook much like Southeastern Kentucky's - a concentrated pro-Union population in the slave south. But unlike Kentucky, Tennessee had seceded, and the congressman worked to elevate the urgency of a federal military response to the relief of his Appalachian citizens.

The advice and requests of Maynard shaped much of Lincoln's correspondence with his generals in the western theatre in the second half of 1861 and at the start of 1862 .

\footnotetext{
${ }^{120}$ For more on General Buell see Stephen D. Engle's “Don Carlos Buell: Misunderstood Commander of the West" in Kent T. Dollar, Larry H. Whiteaker, and W. Calvin Dickinson ed. Border Wars: The Civil War in Tennessee and Kentucky (Kent: Kent State University Press, 2015), 170-193.

${ }^{121}$ Ibid., 23-24. For more on William T. Sherman see John S. D. Eisenhower's American General: The Life and Times of William T. Sherman (New York: Dutton Caliber Publishing, 2015) and James Lee McDonough's William Tecumseh Sherman: In the Service of My Country, (New York: W.W. Norton, 2017).
} 
As early as September 1861, plans to liberate the Unionist portion of Tennessee drew support from Lincoln and the newly appointed General Commander of all Union armies-George B. McClellan. Due to the area's important logistical role in southern railroad commerce, eastern Tennessee stood as a place of strategic military value. But other factors also weighed on President Lincoln. As historian Michael Toomey noted:

Lincoln also believed that he was morally obligated to come to the aid of Southern Unionists wherever possible, and no region of the South had a more visible or active Unionist population than East Tennessee. That such extensive loyalty existed within the bounds of a seceded state was seen as remarkable at the time and has continued to attract the attention of scholars and others who seek to understand the origins and motivations for Southern Unionism in general. It is clear that a number of factors were involved, but it appears that the strength of the Unionist movement in East Tennessee was among rural middle-class farmers. ${ }^{122}$

General McClellan worked on complex plan to advance from Kentucky into eastern Tennessee as part of a "three-way pincer" - with the two additional Union positions closing in from Virginia and the Carolina coast. ${ }^{123}$ Hundreds of miles from Washington, D.C., however, regional Union command in southern Kentucky balked at such recommendations and turned attention away from a possible southeastern thrust to concentrate, instead, on central Tennessee. The military department commanders of Buell (Kentucky) and Union General Henry W. Halleck (Missouri) decided the eastern Tennessee plans were either untenable or logistically impossible. ${ }^{124}$ Buell viewed

\footnotetext{
${ }^{122}$ Michael Toomey, "There Is Shameful Wrong Somewhere: The 1861 Campaign to Liberate East Tennessee," Border Wars: The Civil War in Tennessee and Kentucky, 6365.

${ }^{123}$ Allen C. Guelzo, Fateful Lightning: A New History of the Civil War and Reconstruction (New York: Oxford University Press, 2012), 193-194. ${ }^{124}$ Ibid.
} 
Zollicoffer's move west and, with much more interest, a potential route to Nashville as more pressing targets.

The Confederate Army experienced their own confusion and changes in leadership during the closing months of 1861 as well. The son of famed Kentucky Senator John Crittenden, General George C. Crittenden assumed Confederate command over the occupied district of East Tennessee. Confederate President Jefferson Davis's choice of the West Point-educated Crittenden replaced General Albert S. Johnston's reach at the critical time of Zollicoffer's November reentry into southern Kentucky. Unbeknownst of the changes, Zollicoffer elected to take a westward route to the city of Jamestown, Tennessee, due south of Monticello, Kentucky, to begin a northern march as an alternative to the Cumberland Gap. ${ }^{125}$ In a November 27 message, Zollicoffer reported that the path was bountiful with beef, pork, and corn. Commenting on the war sentiment he encountered the general added that "the better classes of citizens sympathize with us in this part of Kentucky." 126 This message contrasted with the General's September communication where he expressed a frustrated tone during his prior journey through southeastern Kentucky along the Wilderness Road. Zollicoffer arrived outside of Somerset and established a winter camp on the north bank of the Cumberland River at Mill Springs. The camp placed his army between a river and an opposing force; a dangerous choice if faced with the need to retreat. Military historians have speculated

${ }^{125}$ Lowell H. Harrison, The Civil War in Kentucky (Lexington: The University Press of Kentucky, 1975), 24.

${ }^{126}$ F.K. Zollicoffer to General S. Cooper, Nov. 27, 1861, United States War Department, The War of the Rebellion: A Compilation of the Official Records of the Union and Confederate Armies (Washington D.C.: Government Printing Office, 1880-1901), Series.1, Vol. 7, 706-707. 
that the lack of communication during the period of changing Confederate command may have led to Zollicoffer's strategic mistake.

While Zollicoffer's Confederate campaign for a second Kentucky invasion unfolded, Tennessee Unionists stationed in southeastern Kentucky received news in November 1861 that renewed their hopes for a push southward. Much of the arousal stemmed from written confirmation of a series of bridges burned in East Tennessee. Prior to the attack, federal authorities undertook an effort to elevate career naval officer, Samuel P. Carter, to the position of brigadier general. Union command hoped to use the Princeton-educated Tennessean's well-established connections to their military advantage in the Appalachian region. Those plans appeared to coalesce when Carter's younger brother, William, sent message that he had coordinated the destruction of bridges used between Tennessee and Virginia and between Tennessee and Georgia. In November 1861 Colonel Samuel Carter, stationed in London with three Union regiments including Colonel T.T. Garrard's 7th Kentucky Volunteer Infantry, hoped to make a move based upon his brother's reports. Historian Brian McKnight analyzed the effects of the news and concluded:

With local citizens excited to the point of action and knowing that the destruction of those vital east-west links would result in a firm response by the Confederate Army, Samuel Carter urged General Thomas to "urge the commanding general to give us some additional force and let us advance into East Tennessee; now is the time."127

While exciting to the Tennessee Unionists, the destruction did not lead to any immediate change of General Buell's federal plans in the closing weeks of the first year of the war.

${ }^{127}$ Brian D. McKnight, "Reconsidering Felix Zollicoffer: The Influence of Weather and Terrain in the Rise and Fall of a Military Commander in Appalachia," in Kent T. Dollar, Larry H. Whiteaker, and W. Calvin Dickinson ed. Border Wars: The Civil War in Tennessee and Kentucky (Kent: Kent State University Press, 2015), 161-162. 
However, a combination of pro-Union Tennesseans and Kentuckians proved instrumental in the engagement that took shape in southern Kentucky during January 1862.

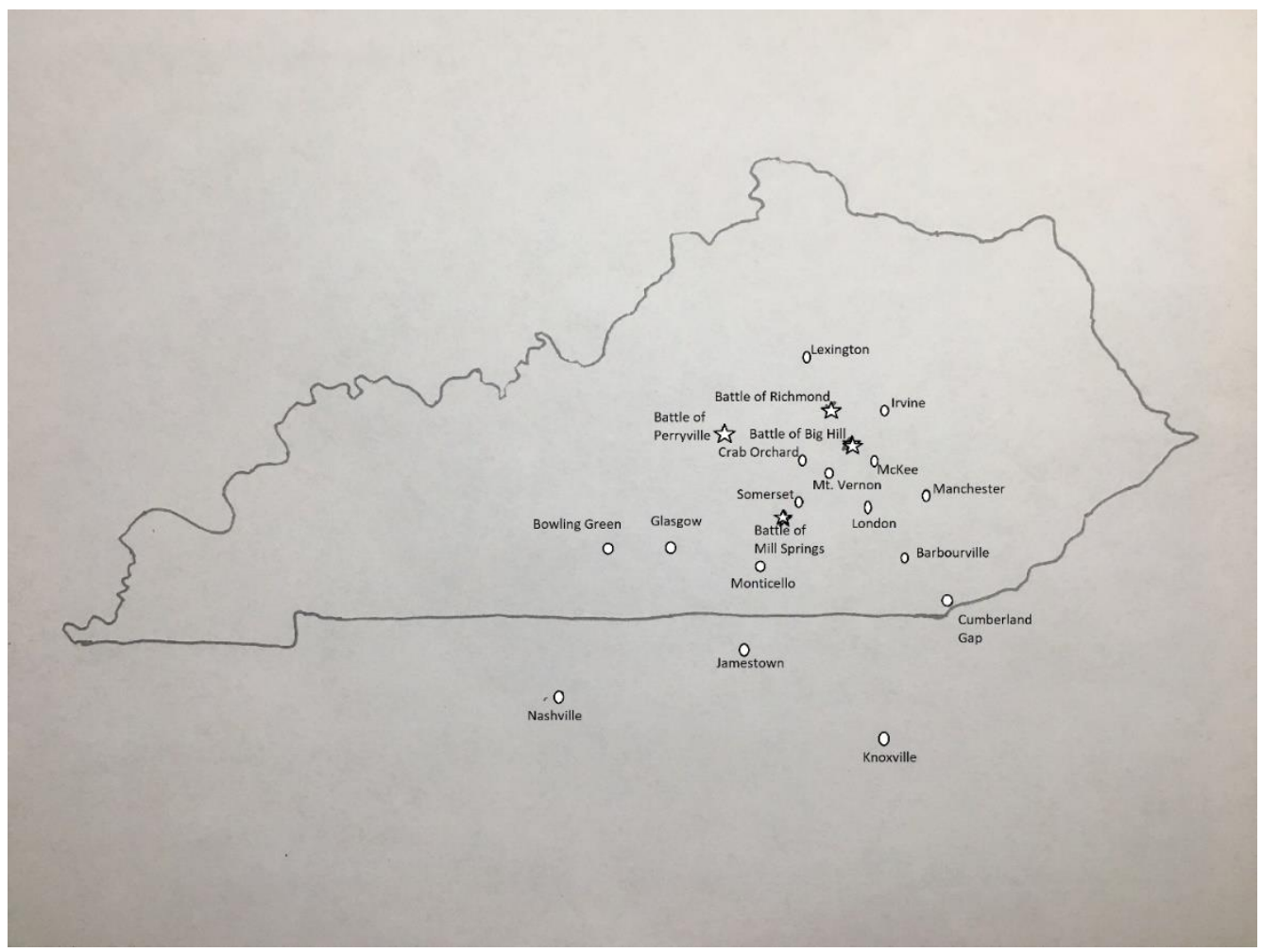

Prior to the Battles of Wildcat Mountain and Mill Springs, in private correspondence Union military leaders disparaged many of the inexperienced Kentucky recruits. In a September 23, 1861 letter from Colonel Thomas Bramlette to General George Thomas, Bramlette remarked that "the inertness of the Union men, their sensationalism, their utter backwardness in rushing to the call of our country is annoying." ${ }^{128}$ By October 1861 General Thomas wrote to General Sherman and added "to advance into Tennessee, I ought to have four more regiments from some other State than Kentucky to follow us as a reserve ... If I could get four additional regiments of Ohio or Indiana volunteers, I would be perfectly willing to dispense with all the

128 “Thomas E. Bramlette to George Thomas," Sept. 23, 1861, United States War Department, Official Records, Series.1, Vol. 4, 270-271. 
Kentucky regiments I have." ${ }^{129}$ In the eastern portion of the state Colonel James A.

Garfield, later the twentieth President of the United States, complained that:

the Fourteenth Kentucky is composed of excellent material, but is in a wretched state of discipline. Very few of its members have been drilled in the school of the soldier, much less that of the company and battalion. It can be considered but little better than a well-disposed, Union-loving mob, which, if its scattered fragments can be gathered up, may be converted into a very serviceable regiment. ${ }^{130}$

Stationed at Camp Calvert near London, General Schoepf struck a different tone and used his correspondence to repeatedly request supplies for his Kentucky men. Many of the southeastern Kentuckians in London who protected the road to Richmond and Crab Orchard lacked the shoes, blankets, and coats needed for winter duty. Soldiers faced a similar predicament near Irvine where Colonel Sidney M. Barnes raised the Kentucky $8^{\text {th }}$ Volunteer Infantry at Estill Springs. These men from Estill, Jackson, and Owsley Counties also suffered from a shortage of equipment. As the group continued to assemble in September 1861, Barnes relayed to General Thomas that:

we camped here yesterday with two full companies raised in this county, and we are looking for another from Owsley County this evening; also one from Jackson County. ... We need blankets, tents, and other camp equipage, and guns, and I know we ought to have them right away. Great activity in the counties around on the part of the secessionists. ... Blankets, tents, and guns will help us and give our people confidence. More depends on this than men ordinarily imagine. The mountain people are peculiar, and I know them. ${ }^{131}$

\footnotetext{
${ }^{129}$ George Thomas to William T. Sherman," Oct. 28, 1861, United States War Department, Official Records, Series.1, Vol. 7, 321-322.

${ }^{130}$ Colonel James A. Garfield to Assistant Adjutant-General,” Jan. 17, 1862, United States War Department, Official Records, Series.1, Vol. 7, 32.

131 "Colonel Sidney M. Barnes to General George H. Thomas," Sept. 23, 1862, United States War Department, Official Records, Series.1, Vol. 4, 269.
} 
The $4^{\text {th }}, 7^{\text {th }}$, and $8^{\text {th }}$ Kentucky Infantries received praise for their organization and discipline in the earliest stages of the war. Many of the other units, at least early, frustrated the command of which they served.

The invading Confederates stationed around Somerset faced their own hardships. Zollicoffer's winter camp boasted around 4000 Confederate soldiers with nearly a quarter who lacked guns to fire at the enemy. Conditions deteriorated during the Kentucky winter and hampered Zollicoffer's hopes for a potential advance east against London or north toward Danville. ${ }^{132}$ With the Confederates hunkered down, Union General Schoepf strengthened his Somerset position in early December with the addition of two regiments of East Tennessee Unionists from Colonel Carter's London force. Buell ordered General Thomas and General Schoepf to launch a tandem attack on the Confederate position just after Christmas. Included in General Thomas's army were the Colonel Speed S. Fry led $4^{\text {th }}$ Kentucky Volunteer Infantry Regiment and the Colonel John Marshall Harlan (later Associate Justice of the United States Supreme Court) led $10^{\text {th }}$ Kentucky Volunteer Infantry Regiment— - both comprised of Kentucky soldiers organized at Camp Dick Robinson. Men from central Kentucky made up the bulk of soldiers for the $4^{\text {th }}$ Kentucky, but volunteers from the southeastern counties of Estill, Laurel, and Rockcastle also served in the ranks. Fry, a strong Unionist, came from a family with central Kentucky ties and his grandfather had even taught the noted emancipationist politician Cassius Marcellus Clay. ${ }^{133}$ Colonel Harlan led central-western Kentuckians in the Kentucky $10^{\text {th }}$.

${ }^{132}$ Harrison, The Civil War in Kentucky, 25.

${ }^{133}$ Sanders, The Battle of Mill Springs, 63. 
Infantry regiments from Minnesota, Ohio, Indiana, alongside a Kentucky volunteer cavalry, rounded out Thomas's troops.

In January 1862, just after Confederate General Crittenden arrived at Mill Springs to assume control, Union General Thomas continued to advance, through rugged conditions, on the Confederate position. The swollen river canceled any ability for relocation. Trapped between the Cumberland River and an approaching federal force, General Crittenden recognized the volatility of his situation and took preemptive action on January 19, sending troops at General Thomas. One of the fiercest encounters of the clash developed between the Union Kentucky $4^{\text {th }}$ and the Confederate Mississippi $15^{\text {th }}$ at a location called Fishing Creek near Logan's Crossroads. The conflict featured soldiers fighting in close proximity, ammunition troubles, faulty weapons, and the order of fixed bayonets. During the heat of the battle, General Zollicoffer mistakenly rode behind enemy lines and into the $4^{\text {th }}$ Kentucky Regiment to issue an order. Once the Union regiment realized the general's identity, Colonel Fry fired his pistol and other Kentuckians launched a volley killing the Confederate leader. Fry, and other veteran Kentuckians of the 4th, told and retold various accounts of the climatic encounter. Colonel Samuel Carter's $12^{\text {th }}$ Brigade experienced heavy fighting during the conflict as well. The $12^{\text {th }}$ Brigade consisted of around fifteen hundred men comprised of the $1^{\text {st }}$ and $2^{\text {nd }}$ East Tennessee Volunteer Infantries alongside the $12^{\text {th }}$ Kentucky Volunteer Infantry. Colonel Carter acted as brigadier general to lead the combination of Tennesseans and Kentuckians. With roots in Garrard County near Camp Dick Robinson, Colonel William Hoskins led the portion of Kentucky volunteers in the $12^{\text {th }}$ and noted the 
cooperation between the units in an official report. ${ }^{134}$ Hoskins regretted "that in this action the soldiers of the Twelfth Kentucky did not have the opportunity of displaying more fully their chivalry" but added that "in any position in which duty may call them they will deport themselves as soldiers worthy the renown of their fathers." ${ }^{\prime 135}$

Colonel John Marshall Harlan offered similar praise for his group of soldiers of the Kentucky $10^{\text {th }}$ Volunteer Infantry. Harlan claimed his men "made a march (18 miles in about six hours) which indicated their willingness, even eagerness, to endure any fatigue or make any sacrifice in order to meet on the field of battle those wicked and unnatural men who are seeking without cause to destroy the Union of our fathers." ${ }^{136}$ In the end, the encounter at Mill Springs resulted in a Union victory and a second Confederate retreat to Tennessee. The conflict involved around 8000 total combatants. The Confederates suffered over 500 killed, wounded, and missing while Union losses numbered under 300. ${ }^{137}$ Many Civil War scholars point to the January 19, 1862 battle as the first major Union victory of the war. On January 22, President Lincoln and Secretary of War Edwin Stanton communicated praise through a congratulatory order in the immediate days that followed the battle:

The President, Commander-in-Chief of the Army and Navy, has received information of a brilliant victory by the United States forces over a large body of armed traitors and rebels at Mill Springs, in the State of Kentucky. He returns thanks to the gallant officers and soldiers who won that victory ... The purpose of this war is to attack, pursue, and destroy a rebellious enemy, and to deliver the country from danger menaced by traitors ... In the prompt and spirited movements and daring battle of Mill Springs the

\footnotetext{
${ }^{134}$ Report of Colonel William A. Hoskins, Twelfth Kentucky Infantry, Jan. 26, 1862, United States War Department, Official Records, Series.1, Vol. 7, 98-99.

135 Ibid., 99.

${ }^{136}$ Report of Colonel John M. Harlan, Tenth Kentucky Infantry, Jan. 27, 1862, United States War Department, Official Records, Series.1, Vol. 7, 90.

${ }^{137}$ Harrison, The Civil War in Kentucky, 27.
} 
Nation will realize its hopes, and the people of the United States will rejoice to honor every soldier and officer who proves his courage by charging with the bayonet and storming intrenchments, or in the blaze of the enemy's fire. ${ }^{138}$

The military success lifted the spirits of a nervous executive who had waited a half-year for a meaningful victory since the disastrous federal defeat in Northern Virginia at Bull Run in July 1861. The event also marked a starting point for other federal advances in the Western Theatre, which stood in great contrast compared to the lack of military progress near the nation's capital. The outcome shaped the early direction of the Border States and darkened the overall Confederate prognostication of the war. Historian Christopher Phillips concluded that "after a string of shocking Confederate defeats [east] of the Mississippi-Mill Springs, Fort Henry, Fort Donelson, Pea Ridge, New Madrid and Island No.10, Shiloh, and New Orleans_-for southerners in the West the spring of 1862 was a season of despair."139

For residents and veterans of Southeastern Kentucky who supported the Union effort, a sense of pride swelled for those who fought near the Cumberland River on that January day. Zollicoffer was dead. Local soldiers proved important, again, and aided the repulse of the second Confederate push into Kentucky. Praise replaced criticism in many of the evaluations of Kentucky Union soldiers in the line of fire. East Tennessee units fought alongside Unionist Kentuckians against enemy soldiers from their respective home states. The differences in military strategy between Lincoln and many of his generals in the field revealed a divide in the priority of aiding the Unionist southerners.

\footnotetext{
138 "Congratulatory Order of the President," Jan. 22, 1862, United States War Department, Official Records, Series.1, Vol. 7, 102.

${ }^{139}$ Christopher Phillips, The Rivers Ran Backward: The Civil War and the Remaking of the American Middle Border (New York: Oxford University Press, 2016), 199.
} 
The westward shift in attention continued and soon after the 1862 spring season, Confederates planned yet another invasion to "liberate" Kentucky.

II.

Events in the western portion of Kentucky pushed the war forward. Following the Confederate defeat at Mill Springs, other early 1862 engagements south of Columbus, Kentucky, moved the center of the conflict toward the Tennessee and Mississippi Rivers. General Ulysses S. Grant won two more important Union victories in Tennessee at Fort Henry and Fort Donelson in early February 1862 — just below the Kentucky state line. With the fall of Fort Donelson General Grant earned the reputation of demanding "unconditional surrender" with his issuance of the order to native Kentuckian turned Confederate General Simon Bolivar Buckner. After the defeat of the Confederates in Mill Springs and at the two river forts, General Albert Sidney Johnston concluded that he could not hold the important city of Bowling Green. ${ }^{140}$ The area surrounding Bowling Green and Barren County was home to some of Kentucky's strongest Confederate sympathizers during Civil War Era. The location even acted as the capital of a makeshift Confederate provisional government where George Johnson served as Kentucky's "Confederate governor." But Union advance put the location between General Thomas's troops to the east and, to the west, General Grant's army near Columbus. On February 11, Confederates began to evacuate the city and destroyed bridges and anything of strategic military value that could not be transported south. Confederate high command

\footnotetext{
${ }^{140}$ Lowell H. Harrison and James C. Klotter, A New History of Kentucky (Lexington: The
} University Press of Kentucky, 1997), 197. 
decided Nashville, too, was indefensible and pulled soldiers even further into secure southern territory. The Union plans of General Halleck and General Buell had a pinching affect that pushed the western Confederate position down into Mississippi.

The large-scale retreat south resulted in the concentration of Confederate forces near Corinth, Mississippi, and led to a climatic April 1862 encounter at Pittsburgh's Landing - known better as the Battle of Shiloh. Located in southern Tennessee above the Mississippi state line, the enormous clash at Shiloh included over 100,000 combatants and featured Kentuckians fighting on each side of the battle. Grant and Buell defeated a Confederate force led by Generals Johnston, Braxton Bragg, and P.G.T. Beauregard as the Union, again, proved victorious. To the shock of the nation, the engagement produced some of the most horrific casualties of the Civil War up to that point and surpassed all prior encounters in the number of soldiers lost on the field of battle. Confederate General Johnston and Kentucky Confederate Governor Johnson were both slain and among the combined 20,000 killed, wounded, and missing. The collective reports that emerged from the Battle of Mill Springs, Fort Donelson, and Shiloh reflected "federal victories [with] each progressively bloodier than any yet fought on this continent."141 Shiloh also did much to end national hopes for a short or limited war, but for Kentuckians the Confederate slide south helped the Commonwealth avoid a major battle fought on its soil during the spring campaign of 1862 . Kentucky state historians James Klotter and Lowell Harrison noted the possible alternative: "The expected battle of Bowling Green had been fought at Shiloh, and the Confederates lost."142

\footnotetext{
${ }^{141}$ Phillips, The Rivers Ran Backwards, 170.

${ }^{142}$ Harrison and Klotter, A New History of Kentucky, 198.
} 
From April to mid-summer in 1862, warfare and major engagements in Kentucky entered a lulled state. Small bands of marauding guerillas replaced large mobile armies. The theft of resources at the hands of Confederate raiders gave rise to minor skirmishes and new federal policies. On May 27, 1862, federal authorities appointed Jeremiah Tilford Boyle, of Mercer County, to oversee the District of Kentucky in an effort to curb guerilla and Confederate activity. ${ }^{143}$ Boyle enacted a policy that assessed the monetary damages of raiders, arrested southern sympathizers, and levied punishment to those who aided the Confederates. ${ }^{144}$ Many of the vulnerable farms and homesteads around areas of the state lacked men, or any type of organized law force, to counter the guerilla activity due to the absence of locals who fought and marched with armies far away. ${ }^{145}$ Violence and lawlessness filled the void. Historian Christopher Phillips provided a vivid summary of the phase:

Bits of news circulated illicitly of brave deaths on battlefields or senseless ones in the camps behind the lines, of wounded soldiers freezing to death and their mercy killings, of unmarked mass graves, and of prisoners being scalped by rebel Indians and merciless guerillas. More frightening, armed nightriders stole indiscriminately, broke into homes, pistol-whipped or harassed white unionists, captured or shot free blacks and slaves, and burned houses and barns. ${ }^{146}$

It was the beginning of a pattern of activity that returned and intensified in Kentucky during the latter half of the war.

Plans for a third, and much more coordinated, Confederate invasion of Kentucky took shape in July 1862. Stationed in eastern Tennessee, Confederate General Kirby

\footnotetext{
${ }^{143}$ Harrison, The Civil War in Kentucky, 34.

144 John E. Kleber, ed. The Kentucky Encyclopedia (Lexington: University Press of Kentucky, 1992), 109.

${ }^{145}$ James C. Klotter and Freda C. Klotter, A Concise History of Kentucky (Lexington: University Press of Kentucky, 2008), 116.

${ }^{146}$ Phillips, The Rivers Ran Backwards, 170.
} 
Smith looked to reenter the state through the Cumberland Gap. Under the command of General George W. Morgan, Union forces occupied the gap and had strengthened their hold on the mountain pass in June 1862 with a flanking movement that moved the Confederates south of the position. ${ }^{147}$ But with Buell's larger Union Army occupied in central and southern Tennessee, the success of John Hunt Morgan's Confederate summer cavalry raids into Kentucky encouraged an anxious Smith to make an advance north.

From Georgetown, Kentucky, John Hunt Morgan sent report that:

I am here with a force sufficient to hold all the country outside of Lexington and Frankfort. These places are garrisoned chiefly with Home Guards. The bridges between Cincinnati and Lexington have been destroyed. The whole country can be secured, and 25,000 or 30,000 men will join you at once. I have taken eleven cities and towns with very heavy arms stores. ${ }^{148}$

Morgan's Confederate raids caught the attention of Union leadership as well. President Lincoln messaged Henry Halleck, stationed in Corinth, Mississippi, to alert the general that "they are having a stampede in Kentucky. Please look to it." "149 From central Kentucky, Thomas Clay confirmed both Lincoln's concerns and Morgan's claims with a July 24 letter to the president that described Morgan's presence in Lexington. Clay indicated a Confederate struggle with the recruitment of locals but concluded with an urgent plea for help as he believed that the raiders posed an imminent danger to the property and people of central Kentucky. ${ }^{150}$

${ }^{147}$ Harrison, The Civil War in Kentucky, 34.

148 “Assistant Adjutant General H.L. Clay to Brigadier General C. L. Stevenson," Jul. 24, 1862, United States War Department, Official Records, Series.1, Vol. 16, 733-734. 149 “Abraham Lincoln to Henry Halleck", The Collected Works V, 1861-62 (New Brunswick: Rutgers University Press, 1959), 322.

150 "Thomas Clay to Abraham Lincoln" Jul. 24, 1862, United States War Department, Official Records, Series.1, Vol. 51, 264-265. 
On August 9, 1862 Smith communicated to General Bragg his plan to move upon the Cumberland Gap and to march toward Lexington. The following day, Bragg replied with a strategy that signaled approval of the plan, but the general counseled caution and suggested that his army should act as a supporting force to disrupt a potential encounter with General Buell's Union troops to Kirby's west. Some of Kirby’s own Kentucky troops further incited the General with predictions that Kentuckians would join the Confederate ranks in large number and that the work of manipulative politicians had kept the state in the Union against the greater will of the people. ${ }^{151}$

General Kirby Smith wanted to test the Union loyalty of East Tennesseans who served in the Union Army first. In an August 13, 1862 pronouncement, Smith proposed:

To the East Tennesseans in the U.S. Army. You must all now be convinced that you have been grossly deceived by the misrepresentation of those under whom you are serving. I therefore announce to you that a final opportunity is afforded you to return to your homes and your allegiance. I offer you a general amnesty for all past offenses, the only condition being that you take the oath of allegiance to the Government and that you conduct yourselves as becomes good citizens. ${ }^{152}$

On the same night, Smith began his northern march toward the Cumberland Gap on a path that resembled Zollicoffer's first invasion a year earlier. The heat and slippery conditions of the roads killed some of Kirby's men, but local Unionists made the journey even more dangerous with the "bushwhacking" of tired Confederate troops. ${ }^{153}$ The march brought Confederates back into southeastern Kentucky and Smith set up camp on August 18 at Barbourville in Knox County. From those headquarters, Smith sent an

\footnotetext{
${ }^{151}$ Harrison, The Civil War in Kentucky, 40.

152 “E. Kirby Smith, Knoxville Headquarters,” Aug. 13, 1862, United States War Department, Official Records, Series.1, Vol. 16, 756.

${ }^{153}$ Kenneth W. Noe, Perryville: The Grand Havoc of Battle (Lexington: University Press of Kentucky, 2001), 37.
} 
August 25 message to General Bragg that expressed both his frustration and optimism. Smith complained of the limited supplies in the area and warned that he would not be able to wait long for the coordinated invasion Bragg wanted to develop, but instead felt that he faced the two options of either a retreat to Tennessee or a march on to Lexington. Like Zollicoffer in 1861, Smith assessed the sentiment around him in Southeastern Kentucky and determined that "thus far the people are universally hostile to our cause. The sentiment extends through the mountain region of Eastern Kentucky." 154 Smith concluded the correspondence with the positive prospect of finding a different situation with local sentiment in the Bluegrass Region of central Kentucky and hoped that he could soon "test their loyalty." 155

A plea from members of the Kentucky Provisional Confederate Congress to Confederate President Jefferson Davis raised Smith and Bragg's optimistic outlooks. Members of the delegation included Robert J. Breckinridge Jr. and George W. Ewing. In the appeal to Davis, the Kentuckians alluded to the restrictive policies of Union General Boyle and stated that once the Confederate force reached central Kentucky "a large majority of the people of the State sympathize with the South and that a large proportion of the young men will at once join our army . ..."156 Between the reports of John Hunt Morgan, optimistic predictions of a favorable outcome from Kentucky's own Confederate soldiers, promises from pro-Confederate politicians, and the lack of a

\footnotetext{
154 "General E. Kirby Smith from Barbourville Headquarters to General Braxton Bragg," August. 24, 1862, United States War Department, Official Records, Series.1, Vol. 16, 775-776.

${ }^{155}$ Ibid.

156 "George W. Ewing et al. to President Jefferson Davis," Aug. 18, 1862, United States War Department, Official Records, Series.1, Vol. 16, 771-772.
} 
formidable Union army presence beyond the Cumberland Gap, Kirby Smith pushed north through southeastern Kentucky with his goals set on reaching central Kentucky.

Before Kirby Smith departed Barbourville, Colonel John Scott's Louisiana Confederate Cavalry moved out in front of the larger invading Confederate force to secure the roads to central Kentucky. Scott's reconnaissance brought him into contact with Union troops in Laurel and Rockcastle Counties. The mounted soldiers of Louisiana struck London first on August 17 and forced Union Colonel Leonidas Hauk's $3^{\text {rd }}$ Tennessee Regiment, who guarded the small city, into a retreat toward the Cumberland Gap. The skirmishes and raids in London opened the opportunity for the Confederates to seize materials, horses, mules, and a shipment of military supplies in the surrounding area. ${ }^{157}$ Next, the Confederates ran into two companies of Colonel T. T. Garrard's $7^{\text {th }}$ Kentucky Voluntary Infantry a little further north in Laurel County. Garrard's detached troops guarded the Laurel Bridge, but the strategic defense proved little obstacle to Scott's superior numbers which ended in another Union retreat - this time to Whitley County. The Confederates continued their advance and descended upon Mt. Vernon before their push toward Richmond, Kentucky.

A larger battle broke out on August 23, 1862 when Scott's Confederates encountered Kentucky-born Mexican-American War veteran, Colonel Leonidas Metcalfe, and his inexperienced $7^{\text {th }}$ Kentucky Calvary on the road between Mt. Vernon and Richmond. On August 21, Metcalfe's officers wired a frantic dispatch from

157 "Report of Colonel John S. Scott, First Louisiana Calvary, commanding Calvary Brigade, including operations from August13-September 11" Sept. 11, 1862, United States War Department, Official Records, Series.1, Vol. 16, Part I., 937-939. 
Rockcastle County to Governor James Robinson (replacement to Beriah Magoffin who

had resigned the office only three days prior) which described his concern:

I learn the Rebels are in Great Force and below Lebanon, about one thousand cavalry and three or four thousand infantry [soldiers] beyond and towards Barbourville. Metcalfe says the country is desolate and no subsistence for man or Beast. He is falling Back and calls loudly for support if General Morgan is to be relieved. We need every man who can raise a gun. ${ }^{158}$

Metcalfe relayed the urgency of his situation in a separate letter to Union Quartermaster

S. B. Brown stationed in Fayette County. Metcalfe warned:

They have destroyed everything south of here and we are feeding the last corn we can get: we cannot live here - there is nothing more for horses-it is all nonsense to talk about feeding the little patches of green corn to our horses, that would starve the women \& children \& kill our horses. There are also four hundred rebels at Mt. Vernon. They are threatening me from both positions \& some danger of them getting between me and Richmond. The Country is perfectly desolated. How the people are to live here I can't see. ${ }^{159}$

The clash developed at a location where Jackson, Rockcastle, and Madison Counties joined. The fresh recruits of Metcalfe's $7^{\text {th }}$ Kentucky Cavalry fared no better against the Confederate force than did the Union troops of the prior days. One key difference was that Metcalf held the numerical advantage. Mustered in near Lexington for less than a month, Metcalfe's unit met Scott's cavalry in an engagement later called the Battle of Big

158 "Unknown to James F. Robinson," 22 August 1862, Office of the Governor, James F. Robinson: Governor's Official Correspondence File, Military Correspondence, 18621863, R2-24, Kentucky Department for Libraries and Archives, Frankfort, KY. Accessed via the Civil War Governors of Kentucky Digital Documentary Edition, discovery.civilwargovernors.org/document/KYR-0001-027-0016, (accessed May 14, 2019).

${ }^{159}$ Leonidas Metcalfe et al. to S. B. Brown, 21 August 1862, Office of the Governor, James F. Robinson: Governor's Official Correspondence File, Military Correspondence, 1862-1863, R2-17, Kentucky Department for Libraries and Archives, Frankfort, KY. Accessed via the Civil War Governors of Kentucky Digital Documentary Edition, discovery.civilwargovernors.org/document/KYR-0001-027-0021, (accessed May 14, 2019). 
Hill. Union reports numbered Scott's Confederates at 1,200 mounted troops during his rounds through southeastern Kentucky, but Scott reported he arrived at the mountainous location with 650. ${ }^{160}$ Scott's approach to Big Hill found Colonel Metcalfe in a strong topographical position and with over one-thousand Union men at his command. ${ }^{161} \mathrm{~A}$ detachment of Hauk's $3^{\text {rd }}$ Tennessee Unionist infantry, led by Lieutenant Colonel John C. Chiles, supported Metcalfe's Kentucky soldiers. Early in the battle, Colonel Metcalfe called for a Union charge at Scott's troops, but when the Colonel looked behind, less than one-hundred of his regiment followed him. ${ }^{162}$ After the failed charge, the Union men continued to break ranks and run from the sound of cannon. Lieutenant Colonel Chiles and the Tennessee battalion provided cover and rescued Metcalfe from the predicament.

The Battle of Big Hill between Scott's Confederates and Metcalfe's Union men marked the largest clash, up to that point, of the August 1862 campaign. The battle resulted in 16 Confederate casualties and anywhere from 50 to 120 Union casualties. Aside from the poor performance of the raw Kentucky soldiers, Confederates captured Metcalfe's horses and found his jacket which contained important details about the Union position at Richmond. ${ }^{163}$ The Union debacle, with untested recruits who suffered a lopsided defeat, foreshadowed a much larger failure to come within the same week only miles away.

\footnotetext{
160 "Report of Colonel John S. Scott, First Louisiana Calvary" Aug. 24, 1862, United States War Department, Official Records, Series.1, Vol. 16, Part I., 885-886.

${ }^{161}$ Ibid.

162 "General Orders, No. 2, Headquarters Army of Kentucky" Aug. 26, 1862, United States War Department, Official Records, Series.1, Vol. 16, Part I., 885.

163 "Report of Colonel John S. Scott, First Louisiana Calvary" Aug. 24, 1862, United States War Department, Official Records, Series.1, Vol. 16, Part I., 886.
} 
The city of Richmond, Kentucky, is the gateway from the mountains of Eastern Kentucky into the Bluegrass region of the state. After Scott's successful clearing of any major Union resistance along the important roads from Barbourville to Richmond, General Kirby Smith marched over 6000 Confederate soldiers to where the Union military strategy had assembled a larger force to impede the Confederate advance. At Richmond, General William "Bull” Nelson commanded a Union army, over 6000 strong, made up of the veteran $18^{\text {th }}$ Kentucky Volunteer Infantry, Lieutenant Colonel Chiles's Tennessee troops from Big Hill, as well as inexperienced soldiers from President Lincoln's July 1862 call for volunteers that included men from Ohio, Indiana, and Michigan — some of whom conducted their first organized drills a day before the engagement. ${ }^{164}$ The August 30 encounter at Richmond proved to be another disaster for the Union. Once again, Union command suffered a defeat as Confederates swept disorganized and inexperienced troops from the battlefield. Even in defeat, the actions of the Kentucky soldiers impressed an Indianan, Brigadier General Charles Cruft. Cruft reported:

The men were all fresh recruits, except the Eighteenth Kentucky, which had seen no field service, very little drill, and was now, for the first time since its formation, collected as a regiment. ... It was, however, impossible, with the troops composing our lines, to stand against the impetuosity of [the Confederate] charge. The center gave way, then the right flank. The left made still a show of resistance, and the Eighteenth Kentucky, Colonel Warner, was brought up to its aid. This regiment made here a gallant fight, and by its brave stand broke the force of the enemy's attack and prevented the retreat at this time from becoming a rout. The

${ }^{164}$ Earl J. Hess, The Civil War in the West: Victory and Defeat from the Appalachians to the Mississippi (Chapel Hill: The University of North Carolina Press, 2012), 96. 
men and officers of most of the regiments, however, fled in confusion to the rear through the fields. ${ }^{165}$

The Union Army mustered in the $18^{\text {th }}$ Kentucky Volunteer Infantry on February 8, 1862 and the unit was active in the pursuit of John Hunt Morgan prior to the Battle of Richmond.

Another Indiana native, Brigadier General Mahlon D. Manson concurred with Cruft's report and described the chaos:

The three remaining regiments of General Cruft's brigade arrived just in time when our troops were on full retreat and the rout had become general, the Eighteenth Kentucky being in advance, under the command of Colonel Warner. This regiment was immediately deployed into the line and made a desperate effort to check the advancing enemy, and contended with him single-handed and alone for twenty minutes, when, after a severe loss, they were compelled to give way before overwhelming numbers. ... The Twelfth Indiana and Eighteenth Kentucky Regiments, being placed in the woods, contended against fearful odds and repulsed the rebels several different times. ... I have neglected to state in the proper place that I was joined in the second engagement by a portion of the Third Kentucky Infantry, who had passed from General Morgan's command at the Cumberland Gap with some Government horses. These men dismounted, hitched their horses, and did excellent service. I do not know the names of any of the accomplished officers who commanded this detachment, or I should gladly give them a place in this report. ${ }^{166}$

Troops from the Kentucky $3^{\text {rd }}$ Volunteer Infantry were part of Colonel Thomas

Bramlette's initial wave of volunteers who organized at Camp Dick Robinson. The aid of those veteran soldiers may have impressed the Indiana command, but it did little to affect the outcome. Scott's cavalry intercepted the retreat and General Nelson's Union

165 "Report of Brigadier General Charles Cruft, Commanding Second Brigade" Sept. 5, 1862, United States War Department, Official Records, Series.1, Vol. 16, Part I., 918923.

166 "Report of Brigadier General Mahlon D. Manson, U.S. Army" Sept. 10, 1862, United States War Department, Official Records, Series.1, Vol. 16, Part I., 910-916. 
men suffered around 1,000 casualties and 4,300 lost as prisoners. ${ }^{167}$ Smith and the Confederates lost fewer than 500 soldiers.

The engagement at Richmond opened the road to central Kentucky and occurred during the same days as the Union defeat in northern Virginia at the Second Battle of Bull Run. Historian Kenneth Noe added, "the Battle of Richmond would be the most lopsided Confederate victory of the war, as Kirby Smith's men inflicted casualties so staggering that entire Union brigades ceased to exist." ${ }^{168}$ With Buell's veteran army away in Tennessee, the Union lacked a large supply of experienced soldiers to check momentum of the invading force. The Battles of Big Hill and Richmond stood in stark contrast to the outcomes at Wildcat Mountain and Mill Springs where the Union prevailed. Unlike Zollicoffer's first two Confederate invasions, General Smith executed a plan to penetrate the central portion of the state, cut his army off from secure lines of communication in a show of confidence, and even compared the journey that anticipated no retreat to Hernan Cortes's conquest of the Aztecs. ${ }^{169}$

The Confederate Army occupied Lexington on September 1, 1862, and Frankfort in the days that followed. General Kirby Smith, content to wait in Lexington for Bragg's larger army to join him, elected not to advance his army on the open road to Louisville or Cincinnati where citizens waited in fear for the next Confederate move. Instead, Smith only sent small detachments north and northwest to the populated locations on the Ohio River. The Confederate General kept most of his troops in Lexington and hoped to add

${ }^{167}$ Harrison, The Civil War in Kentucky, 41-42.

168 Noe, Perryville, 39.

${ }^{169}$ Hess, The Civil War in the West, 96. 
recruits from around the Bluegrass region to enlarge his army. ${ }^{170}$ The pro-Confederate sympathies of central Kentucky raised the expectations of the invading force as citizens of Lexington greeted Smith's troops with dozens of Confederate flags and enthusiasm. ${ }^{171}$

Confederate General Bragg began his move north toward Kentucky from Chattanooga on August 28, 1862 — two days before the Battle of Richmond. With a force of more than 30,000 battle-hardened troops, Bragg crossed the Tennessee River, then the Cumberland River, marched through Middle Tennessee, and reentered Kentucky near Glasgow. Much of the Confederate advance went undetected by the Union military. The Lincoln administration, aware of the disastrous results from Richmond, Kentucky, and the Second Bull Run in Virginia, panicked at the loss of observation of the large force in the early weeks of September. President Lincoln sent an inquiry on September 7 to General Boyle and asked "Where is General Bragg? What do you know on the subject?" and another to General Buell with the question of "What degree of certainty have you, that Bragg, with his command, is not now in the valley of Shenandoah, Virginia?"172 Buell assured Lincoln that Bragg was in Tennessee and that his army would look to stop the Confederate plans in Kentucky.

General Bragg arrived at Glasgow, Kentucky, on September 13, 1862 with a message that echoed General Smith earlier tests of loyalty. Bragg announced:

Kentuckians, I have entered your State with the Confederate Army of the West and offer you an opportunity to free yourselves from the tyranny of a despotic ruler. We come not as conquerors or as despoilers, but to restore to you the liberties of which you have been deprived by a cruel and

${ }^{170}$ James L. McDonough, War in Kentucky: From Shiloh to Perryville (Knoxville: The University of Tennessee Press, 1994), 153-154.

${ }^{171}$ Hess, The Civil War in the West, 97.

172 "Correspondence with Jeremiah T. Boyle and Don C. Buell," September 7, 1862, The Collected Works V, 1861-62 (New Brunswick: Rutgers University Press, 1959), 408-409. 
relentless foe. ... Will you remain indifferent to our call, or will you not rather vindicate the fair fame of your once free and envied state? ${ }^{173}$

The strategic location of Bragg's Army, between Smith's force that occupied Lexington and Buell's Union army that caught up from Nashville, put Confederate plans in a strong position for success. ${ }^{174}$ But the ease of Confederate plans for a takeover of Kentucky started to decline after Bragg left Glasgow. Buell's force, the Union Army of the Ohio, entered Bowling Green over thirty miles west of Glasgow around the time Bragg offered his proclamation. Bragg, in effort to keep his army between Buell and Smith, marched north on September 15 and encountered a situation in Munfordville - an import railroad town with an elevated rail bridge near Mammoth Cave and Lincoln's Hodgenville birthplace - that delayed the advance. Bragg selected the native-born General Simon Bolivar Buckner to accompany him in an effort to win over fellow Kentuckians, and after a few days of deployments that surrounded the position, Buckner negotiated and accepted the surrender of the Union troops guarding the Munfordville rail line on September 17the same day as the Battle of Antietam in Maryland.

The days lost at Munfordville proved critical to Bragg's Confederate Army. Buell's Union troops raced for Louisville and Bragg set up headquarters in Bardstown, with the expectation of a rendezvous with General Kirby Smith's smaller force. Smith's troops, however, supported a Confederate cavalry engaged with Union troops at Mt. Sterling, east of Lexington, over a hundred miles away. The two Confederate armies drifted further apart, and the lack of communication impacted coordination. Bragg's situation also deteriorated when any achievable goal, central to a strategic Confederate

173 "Headquarters, Department No. 2, Braxton Bragg" Sept. 14, 1862, United States War Department, Official Records, Series.1, Vol. 16, Part II., 822-823.

${ }^{174}$ McDonough, War in Kentucky, 157. 
military outcome, seemed to evade the general. Kentucky historian Lowell Harrison added, "But on one important point the Confederate commanders were united: they shared a bitter disappointment over the failure of Kentuckians to join their armies in large numbers. The wagon trains had hauled thousands of stands of arms to equip the anticipated horde of volunteers, but most of the rifles remained in the wagons, despite the obvious Confederate sympathy of many of the state's inhabitants." 175 Another problem, Kentucky's heat and conditions of drought, pushed the armies to search for water. Perryville emerged as one of the locations thought to have the precious resource.

III.

The important encounter at Perryville marked a turning point for the 1862 Confederate campaign in Kentucky and for the broader Western Theatre in general. After a few weeks in central Kentucky, including a brief occupation of the capitol in Frankfort, General Bragg planned an October 4 Confederate gubernatorial inaugural ball for the slain George Johnson's replacement—Kentucky's second Confederate Governor, Richard Hawes. ${ }^{176}$ Bragg hoped the placement of Hawes as a state executive would signal proof of a permanent Confederate presence and that the new appointed governor could provide a means to enforce a conscription law to draft soldiers into the invading southern ranks — a measure the Confederate legislature passed in the spring of $1862 .{ }^{177}$ However, Buell's large Union army disrupted those plans through military pressure and forced the Confederates to turn away from their political focus. By October 8, 1862, a series of Union movements had pushed Confederates out of Frankfort and other northern

${ }^{175}$ Harrison, The Civil War in Kentucky, 47.

${ }^{176}$ Harrison and Kotter, A New History of Kentucky, 201.

${ }^{177}$ Ibid. 
portions of the state where they drifted south and collected with Bragg's other scattered divisions in central Kentucky looking for water around the town of Perryville. The largest battle ever fought in Kentucky followed. A portion of Bragg's army, 16,000 men, attacked Buell's force of 55,000.

Divided into three corps, Generals Don C. Buell and George H. Thomas led the Union Army of the Ohio. General Alexander McCook commanded the First Corps, General Thomas L. Crittenden — another son of former Senator John J. Crittenden and brother of Confederate General George Crittenden—commanded the Second Corps, and General Charles C. Gilbert led the Third Corps. The First Corps experienced most of the fighting at Perryville, followed by the Third who saw some action, while the Second Corps did not play a significant role due to the confusion that surrounded the battle. ${ }^{178}$ Unaware of the consolidation of the Union force, Bragg launched an attack against superior numbers. For Buell, a phenomenon known as an "acoustic shadow" prevented a larger engagement as the General did not hear the start of the battle even though the cannons thundered only a few miles away. ${ }^{179}$ This atmospheric condition delayed the Union's ability to capitalize on their numerical advantage. Even with the uncoordinated deployment of troops, the Battle of Perryville developed into the largest engagement and produced the costliest totals for Kentucky during the entire Civil War. The one-day encounter resulted in 4,211 casualties for the Union and 3,396 for the Confederates. ${ }^{180}$

\footnotetext{
${ }^{178}$ Hess, The Civil War in the West, 102; Noe, Perryville, 373-380.

${ }^{179}$ James M. McPherson, Battle Cry of Freedom: The Civil War Era (New York: Oxford University Press, 1988), 520.

${ }^{180}$ Harrison, The Civil War in Kentucky, 53.
} 
The two groups comprised of the most Southeastern Kentuckians experienced two different roles at the Battle of Perryville. Colonel Sidney Barnes and the $8^{\text {th }}$ Kentucky were present, under General Crittenden's command, but like most of the soldiers of the Second Corps, not called into action. In contrast, Colonel T.T. Garrard's $7^{\text {th }}$ Kentucky played a significant role as part of the First Corps, $10^{\text {th }}$ Division, $33^{\text {rd }}$ Brigade. Garrard led a detachment comprised of one company of the original $7^{\text {th }}$ Kentucky Volunteers formed of southeastern Kentucky men, a company of $32^{\text {nd }}$ Kentucky Volunteers, and one company of $3^{\text {rd }}$ Tennessee Volunteer Infantry. The group of 193 soldiers provided support for an artillery battery alongside Ohio, Wisconsin, Pennsylvania, and Illinois Infantries. ${ }^{181}$ The $33^{\text {rd }}$ Brigade found itself engaged in some of the heaviest fighting of the entire field and located between two potential sources of water-Wilson's Creek and Chaplin River—near Benton Road. Colonel Garrard's detachment suffered one killed, thirty wounded, and eight missing, while the entire $10^{\text {th }}$ Division, made up of just two brigades, accounted for over a quarter of all Union casualties at Perryville. ${ }^{182}$

The Union's Third Corps experienced varying levels of participation at Perryville. General Schoepf and General Fry, both important in repelling Zollicoffer's two prior invasions, helped command parts of the $1^{\text {st }}$ Division in the Third Corps, but the veteran officers did not participate in a major engagement at the battle. The $1^{\text {st }}$ Division included the $4^{\text {th }}, 10^{\text {th }}$, and $12^{\text {th }}$ Kentucky Volunteer Infantries. General Phil Sheridan led a separate division in the Third Corps that employed the aid of the $9^{\text {th }}$ Kentucky Calvary. Sheridan, who went on to become one of the most important generals by the war's end, sustained

\footnotetext{
181 Noe, Perryville, 201.

182 Ibid., 374.
} 
significant casualties at Perryville, although the Kentucky Calvary unit incurred only a minor role.

The early confusion benefitted the Confederates and evened the numbers for Bragg's attacking force. Historians have even judged the results at Perryville as a "tactical victory" for the Confederates. ${ }^{183}$ However, by the day's end, Bragg decided to retreat to Tennessee after he realized the size of the force he faced, weighed the cost of the battle, and speculated about his prospects in Kentucky. Bragg's retreat south brought the Confederate Army back into contact with Southeastern Kentuckians. On October 12, Bragg met with Confederate command to decide to march to the relief of Chattanooga where Confederate reinforcements were needed. ${ }^{184}$ The lack of local Kentuckians joining the Confederate ranks did a great part to affect the decision. An estimated 2,500 Kentucky citizens took up arms for Bragg's army, much less than the 25,000 to 30,000 volunteers that some of the southern leadership had predicted and at a rate that did not even cover the losses of the campaign. ${ }^{185}$ Both Bragg and Smith disparaged the unwillingness to find support in Kentucky. ${ }^{186}$ The Confederate Army marched to Harrodsburg first, then Danville, before arriving at Lancaster where Bragg decided to split the force. From Lancaster, worried about the numerous armed Unionists sure to be found along the way, Bragg chose to take his army through Crab Orchard, sent Confederate General Marshall's troops toward Virginia, and instructed Kirby Smith to

\footnotetext{
${ }^{183}$ Patrick Lewis, For Slavery and Union: Benjamin Buckner and Kentucky Loyalties in the Civil War (Lexington: University Press of Kentucky, 2015), 97.

${ }^{184}$ Harrison, The Civil War in Kentucky, 54.

185 Ibid.

${ }^{186}$ Braxton Bragg to Wife, Nov. 9, 1862, Bragg Letters (Special Collections, University of Kentucky, Lexington) and "Kirby Smith to Braxton Bragg" Sept. 18, 1862, United States War Department, Official Records, Series.1, Vol. 16, Part II., 845-846.
} 
move back toward the hostile area of Big Hill. ${ }^{187}$ Union General Buell chased the fleeing force as far as London, where he abandoned the pursuit to turn his attention, once again, to Middle Tennessee.

Some historians have analyzed the Confederate invasion of Kentucky as part of a broader strategy that linked the two theatres, East and West, together. Christopher Phillips called the coordinated effort the "Confederate Tet." 188 Historian James McPherson judged the results of the Confederate invasion and subsequent withdrawal as part of a progression of major turning points that affected the eventual outcome of the war:

The first [critical point] occurred in the summer of 1862, when the counter-offensives of Jackson and Lee in Virginia and Bragg and Kirby Smith in the West arrested the momentum of a seemingly imminent Union victory. This assured a prolongation and intensification of the conflict and created the potential for a Confederate success, which appeared imminent before each of the next three turning points. The first of these occurred in the fall of 1862, when battles at Antietam and Perryville threw back Confederate invasions, forestalled European mediation and recognition of the Confederacy, perhaps prevented a Democratic victory in the northern elections of 1862 that might have inhibited the government's ability to carry on the war, and set the stage for the Emancipation Proclamation which enlarged the scope and purpose of the conflict. ${ }^{189}$

The impact of the failed invasion changed the path of the war. Privately President Lincoln acknowledged the sacrifice of the soldiers in an October 8, 1862 letter to Thomas H. Clay where Lincoln denied Clay's request_ on the same day as the Battle of Perryville — to place additional Union soldiers in Cincinnati, Ohio, to protect exiled Kentucky Unionists. Lincoln added, “Buell's old troops, now in pursuit of Bragg, have

${ }^{187}$ McDonough, 309-310.

${ }^{188}$ Christopher Phillips, The Civil War in the Border South (Santa Barbara: Praeger Books, 2013), 49-64.

${ }^{189}$ McPherson, Battle Cry of Freedom, 858. 
done more hard marching recently. And, in fact, if you include marching and fighting, there are scarcely any old troops East or West of the mountains that have not done as hard service." 190 Lincoln's admiration expressed toward the Army of the Ohio troops did not extend to the General himself.

Buell's movements, and lack of communication, concerned President Lincoln. At the critical juncture of pursuit, the General avoided contact with the Commander-inChief. In two separate telegraphs in mid-October, Lincoln reached out to General Boyle and asked, "please send any news you have from Gen. Buell to-day," and followed the next day with "we are very anxious to hear from Gen. Buell's Army. We have had nothing since day-before yesterday. Have you anything?"191 Lincoln wanted Buell to pursue Bragg's retreat though the rest of southeastern Kentucky and to the relief of Eastern Tennessee. General Halleck relayed the President's wishes to Buell and questioned the General's logistical reluctance to carry out Lincoln's objective. Halleck ended the directions with the assurance, "once [you] hold the valley of the Upper Tennessee, the operations of guerillas in that State and Kentucky will soon cease."192 Buell refused to follow the path through the Cumberland Gap and raised the issue that insufficient resources in the area would not support an advance. Lincoln's patience wore out. On October 30, 1862, General William S. Rosecrans assumed command of the Army of the Ohio after Lincoln removed Buell from his position and, shortly thereafter,

\footnotetext{
190 "To Thomas H. Clay from Abraham Lincoln," October 8, 1862, The Collected Works V, 1861-62 (New Brunswick: Rutgers University Press, 1959), 452.

191 "To Jeremiah T. Boyle from Abraham Lincoln," on October 11, 1862 and October 12, 1862, The Collected Works V, 1861-62 (New Brunswick: Rutgers University Press, 1959), 457-458.

192 "General Halleck to General Buell” Oct. 19, 1862, United States War Department, Official Records, Series.1, Vol. 16, Part II., 626-627.
} 
the Department of the Cumberland renamed the veteran group the Army of the Cumberland.

Between Lincoln's October message to General Boyle and his removal of Buell, a development in Southeastern Kentucky illuminated the cost and sacrifice endured by the civilian population during the Civil War. Without the occupation of a formidable Union force in Southeastern Kentucky to guard resources, General Crittenden of the Second Corps for the Union Army issued orders to destroy the Goose Creek Salt Works inside Clay County, Kentucky. A conglomerate of owners had claim to the salt production and operations for the business spread over several locations. Less than two months from his command at the Battle of Richmond, the Union Army selected Brigadier General Charles Cruft to carry out the order and he began the two-day destruction on October 23, 1862. Cruft's night arrival to the location found a large Confederate cavalry that occupied a nearby farm. The Confederates broke camp and scurried away. General Cruft also reported that "the people in the mountain districts in direction of Manchester are loyal and true to the Government. They have been robbed by the rebel army of nearly all of their available property—cattle, horses, and crops—and are left generally in a destitute condition." 193 Soldiers destroyed the bored wells, over five-hundred feet deep, pumps and the drills necessary for new wells. The commodity lost represented a very important nineteenth-century means to preserve food for the communities surrounding the area. But Confederate raids and guerilla warfare thrust women and children into the effects of war, as the shortage of food threatened starvation to many segments of the population

193 "Report of Brig. Gen. Charles Cruft, U.S. Army" Oct. 25, 1862, United States War Department, Official Records, Series.1, Vol. 16, Part II., 1150-1151. 
across the country. ${ }^{194}$ On the recommendation of General Cruft, the Union Army allowed local citizens to take as much salt as they needed before completion of the destruction. An Ohioan and West Point graduate, Brigadier General William Sooy Smith added:

The Salt-Works are situated in the midst of a population whose loyalty and patriotism are not excelled in any portion of our country. Much suffering must result to the poor people in the surrounding region from the lack of salt . . . the noble conduct of some of those interested in the works, especially of Mrs. Garrard, who expressed her entire willingness that not only that valuable property, but all else that she and her husband (a colonel in our service [T.T. Garrard]) owned, might be destroyed if such destruction would help restore the Union, constrains an earnest recommendation that prompt restitution be made for the damage done. ${ }^{195}$

In an area that both Union and Confederate officials deemed poor throughout 1862, the Garrard family surrendered a huge portion of the best resource the locality possessed for the Union cause and offered to sacrifice even more material aid than requested. The act symbolized much of what the population that surrounded the location were willing to give to stop the Confederate occupation.

Events in Kentucky during 1862 brought the war up close to residents who lived in the Commonwealth. For the men who volunteered for the Union Army, military service resulted in long marches, a privation of resources, and violent encounters. Civilians in the area experienced the theft, destruction, and shortage of food. The 1861 Battle of Wildcat Mountain and the early 1862 Battle of Mill Springs stopped Confederate advance in southern Kentucky before it could reach the Bluegrass Region.

${ }^{194}$ Drew Gilpin Faust, This Republic of Suffering: Death and the American Civil War (New York: Knopf Books, 2008), xi-xii.

195 “Report of Brig. Gen. W.S. Smith” Nov. 16, 1862, United States War Department, Official Records, Series.1, Vol. 16, Part II., 1149. 
But in the summer of 1862, General Kirby Smith exposed the Union's diverted attention to central Tennessee and entered Kentucky through the Cumberland Gap in a campaign that endangered the state's place in the Union. The mountainous topography-and a population loyal to the Union - helped disturb the beginning of that campaign. Some of the armed men left behind to guard the state, including several like-minded Eastern Tennessee Unionists who were often paired with southeastern Kentucky Unionists, suffered casualties and put up resistance against Smith's invasion. Perhaps more important, Kentuckians and Tennesseans loyal to the Union did not join the ranks of Confederates in any significant number during the invasion. Separate appeals promising liberty and amnesty from the invading Confederate generals had little effect on strengthening their numbers. The disagreements between President Lincoln's desire to come to the aid of Unionist southerners and General Buell's refusal to advance through the portion of the country necessary to that aim left the Appalachian civilians in a tough situation. Evidence, including numerous accounts from military leaders of both sides, suggests that the Union loyalty and resolve of the population in Southeastern Kentucky remained firm. 


\section{CHAPTER FOUR \\ "AS SOLIERS SUFFER TO ANYTHING, EVEN UPON DEATH": KENTUCKY AND THE SECOND HALF OF THE CIVIL WAR}

Many historians break the five-year period of the American Civil War into two halves. Carrying out strategies for politicians, Union and Confederate generals fought the first half of the war with eighteenth century tactics and manners. This approach produced horrific casualties as soldiers with modern weapons met on remote battlefields and volleyed musket and cannon fire into long lines of exposed soldiers. The second half of the war devolved into a much uglier reality. The war continued to cause alarming casualty rates and some military leaders clung to those old tactics, but the successful targeting of infrastructure and resources added effects felt by civilian populations. The loss of those resources caused armies to take entrenched defensive positions or to raid communities for much needed materials. Some historians have labeled the turn a "total war" or a "hard war." This model of "halves" may or may not reflect the nature of the Civil War; but, the model does apply to the experience of Kentucky during the national conflict. In Kentucky, guerrilla warfare replaced the large organized and foraging armies of 1861 and 1862. For the second half of Civil War in Kentucky, Union volunteers from the state played significant roles in securing important victories in the Western Theatre of the war and in defending Kentucky against raids and local uprisings. The state population faced violent upheaval from frequent Confederate invasions and the political fallout from local residents in reaction to new federal policies. Southeastern Kentucky 
continued to provide a strong loyalty to the Union cause during the post-emancipation phase of the Civil War, while most of the state experienced a fracture or shift in national sympathies.

I.

The Confederate decision to abandon large-scale military operations in Kentucky following the failed 1862 invasion provided some relief for the Unionists of Southeastern Kentucky and for the Commonwealth in general. Concluding with General Braxton Bragg and General Kirby Smith's hasty retreat into Tennessee, many standard accounts on the Civil War depart from offering any further historical insight about the war's impact on Kentucky. President Abraham Lincoln's October 1862 replacement of General Don Carlos Buell with General William S. Rosecrans to command the Army of the Ohio (afterwards renamed the Army of the Cumberland) signaled an ongoing difference in military strategy related to the Appalachian region-with Buell's reluctance to pursue a retreating enemy through southeastern Kentucky or to liberate East Tennessee as major factors that led to his dismissal. ${ }^{196}$ However, General Rosecrans's approach did not bring an immediate change in strategy, nor a large Union presence, to the Appalachian Mountains. Like Buell, Rosecrans focused on securing central Tennessee. But the Union Army's October 1862 follow-up destruction at Manchester of the Goose Creek Salt Works suggested the Civil War would continue to affect Southeastern Kentuckians. Even with the Union's dismantling of attractive resources in effort to deter a Confederate

196 James M. McPherson, Tried by War: Abraham Lincoln as Commander in Chief (New York: The Penguin Press, 2008), 267-268. 
return and the absence of a large military occupation by either side, Civil War activity remained close to the local population. In December 1862, Union military plans brought the movement of troops back to the southeastern portion of Kentucky again, only a couple of months after the Battle of Perryville and the subsequent Confederate retreat.

In the fall of 1861, Tennessee Unionists led the destruction of a series of southern railroad bridges to attract federal attention to an area sympathetic to the Union but under Confederate control. Those attacks did not move the Union Army to act. A year later, however, Union officials revived Samuel P. Carter's November 1861 original request to infiltrate and target infrastructure in eastern Tennessee. Moved up from colonel to the rank of brigadier general, officials selected Carter to lead a small expeditionary force with orders to strike the East Tennessee and Virginia Railroad. ${ }^{197}$ Three weeks later the effort began to unfold when General Carter left Lexington, Kentucky, and traveled south with the $2^{\text {nd }}$ Michigan Calvary and the $9^{\text {th }}$ Pennsylvania Calvary. The group marched up Big Hill, to Jackson County, where the soldiers waited two days in the town of McKee for a delayed provision train. ${ }^{198}$ Leaving McKee on Christmas Eve, Carter's route went through Clay County, toward Red Bird River, where the $7^{\text {th }}$ Ohio Calvary joined the group and bolstered the numbers of the expeditionary unit to over nine-hundred men. Next, the force crossed Pine Mountain on December 28, traveled both day and night, and

\footnotetext{
197 "Report of Brigadier General Samuel P. Carter, Jan. 9, 1863, United States War Department, The War of the Rebellion: A Compilation of the Official Records of the Union and Confederate Armies (Washington D.C.: Government Printing Office, 18801901), Series.1, Vol. 20, Part I, 88.

198 "Report of Colonel Charles J. Walker, Jan. 9, 1863, United States War Department, The War of the Rebellion: A Compilation of the Official Records of the Union and Confederate Armies (Washington D.C.: Government Printing Office, 1880-1901), Series.1, Vol. 20, Part I, 93.
} 
entered the southwestern portion of Virginia through a pass called Crank's Gap located near Harlan, Kentucky. Once in Virginia a few Confederates, believing the mounted troops to be friendly cavalry, passed through the lines of Carter's infantry and the small Union force captured the confused soldiers. News began to spread ahead of the group that a Union advance from Kentucky was underway, but southern locals dismissed the reports as unbelievable. ${ }^{199}$

After an undetected arrival in Tennessee on December 30, the $2^{\text {nd }}$ Michigan Calvary led an attack on a railroad line near the town of Blountsville. The Union military encountered and captured thirty soldiers from Colonel Henry L. Giltner's Confederate $4^{\text {th }}$ Kentucky Cavalry. General Carter's troops managed to evade the larger Confederate presence in the area and executed the destruction of a 150-foot-long railroad bridge over the Holston River in a town once called Union, (at the time renamed Zollicoffer) Tennessee. General Carter's brother, Colonel James P.T. Carter, led a detachment of Ohio, Pennsylvania, and Michigan soldiers that destroyed another important railway bridge over the Watauga River, ten miles west of Union. ${ }^{200}$ The expeditionary force also laid waste to several supplies of Confederate material aid, a wagon bridge, and other equipment in addition to burning the two railroad bridges. As the Confederates began to mount a counterattack in reaction to the destruction, General Carter, outnumbered and deep within Confederate territory, called for his men to leave the area on a path that retraced their arrival. Armed bushwhackers and Confederate infantry disrupted the Union's departure during their trek back through the mountain passes of Tennessee and

${ }^{199}$ Samuel P. Carter, Official Records, Ser. I, Vol. 20, Part I, 89. ${ }^{200}$ Ibid. 
Virginia. Carter's men made a strenuous non-stop march that crossed the Cumberland mountains and reentered Kentucky through Crank's Gap on January 2, 1863. The group reached southeastern Kentucky on January 5 and, in an area safe from Confederate harm, General Carter allowed soldiers a couple days rest before their return to the central portion of the state.

Union command heaped praise upon the actions of Carter and his men. The operations in East Tennessee resulted in less than twenty casualties for the entire unit while reports counted over five-hundred killed, wounded, and captured Confederates as a result of the stealth journey into the South. ${ }^{201}$ General-in-Chief of the Union Army Henry W. Halleck responded to a summary of General Carter's work in Tennessee and concluded that "the daring operations and brilliant achievements of General Carter and his command are without a parallel in the history of the war." ${ }^{202}$ In his own report, General Carter acknowledged the leadership of the Kentucky cavalry who had accompanied him on the expedition. Carter also singled out two individuals to credit for the mission's success:

To Colonel [James] Carter's knowledge of the people and country in the vicinity of the railroad bridge is mainly due our success at those points, with so small a loss of life. Colonel [T.T.] Garrard, an officer of sound judgement and great discretion, was of invaluable service in passing through the mountains of Eastern Kentucky. He gave his whole heart to the work and was of great service to the expedition. ${ }^{203}$

201 "Major General Horatio G. Wright to Major General Granger," Jan. 7, 1863, United States War Department, The War of the Rebellion: A Compilation of the Official Records of the Union and Confederate Armies (Washington D.C.: Government Printing Office, 1880-1901), Series.1, Vol. 20, Part I, 87.

202 "General Halleck to General Wright," Jan. 9, 1863, United States War Department, The War of the Rebellion: A Compilation of the Official Records of the Union and Confederate Armies (Washington D.C.: Government Printing Office, 1880-1901), Series.1, Vol. 20, Part I, 87.

${ }^{203}$ Samuel P. Carter, Official Records, Ser. I, Vol. 20, Part I, 92. 
Colonel Garrard directed Union soldiers through southeastern Kentucky without any significant violent confrontations in the area-an experience that contrasted with the type of encounters Union soldiers faced in eastern Tennessee and southwestern Virginia. Tennessee Unionist Colonel James Carter, who had already served as future president Andrew Johnson's bodyguard in June 1861, utilized his local knowledge of the area south of Kentucky to help carry out the plan. ${ }^{204}$ The achievement owed much to the cooperation between Unionists of Southeastern Kentucky who provided safe passage and Unionists of Eastern Tennessee, determined to free the area of Confederate control, working together to aid the mission's success.

The impact of the expeditionary force did not offer immediate relief for the Unionist citizens, but the effort was important in disrupting the flow of materials to Confederates during a larger engagement to the southwest. Around the same time of the Carter brothers' destruction of Confederate targets in northeastern Tennessee, the larger Army of the Cumberland moved in to attack Bragg's Army of Tennessee at a location south of Nashville near Murfreesboro, Tennessee. The movement constituted part of a broader strategy that coincided with the beginning of General Ulysses S. Grant's siege of Vicksburg, Mississippi, to the west, and General Ambrose Burnside's attack against General Robert E. Lee at Fredericksburg, Virginia, to the east. But in the weeks before that offensive took place, Union command started to note the preliminary fallout from the Emancipation Proclamation. President Abraham Lincoln's September 1862 announcement of the Emancipation Proclamation, and the war's new developments that

\footnotetext{
${ }^{204}$ John S. Goff, "Colonel James P. Carter of Carter County," Tennessee Historical Quarterly, 26, (Winter, 1967): 374.
} 
targeted southern slavery after the Union victory at Antietam, produced internal critics within the Union ranks. The proclamation acted as a war measure that declared freedom to all slaves as a military exigent in areas under Confederate control. Border State suspicions that the abolition of all slaves might follow more battlefield successes presented new challenges for the Army of the Cumberland during the winter campaigns of late 1862 and early 1863 . Union officers who expressed negative opinions related to the emancipation of slaves raised alarm among both the executive administration in Washington and the highest-ranking generals in the field. ${ }^{205}$

Early in his appointment, General Rosecrans worried about how reactions to emancipation could influence the morale and strength of the Army of the Cumberland. Those concerns were well placed. In the first weeks of his command, records reveal that 6,484 soldiers had left Rosecrans's Army of the Cumberland without permission either during or just prior to his takeover-including many disgruntled Kentucky troops who had not received pay for eight or nine months. ${ }^{206}$ Central Kentucky figures, such as Major Benjamin Forsythe Buckner of the $20^{\text {th }}$ Kentucky Volunteer Regiment, expressed a bitterness and developed an open hostility toward executive emancipation in late 1862 that symbolized many pro-slavery Unionists' opinion of Lincoln's effort. ${ }^{207}$ Some of the officers resigned, numerous more soldiers deserted, and historians have explored the

${ }^{205}$ Larry J. Daniel, Days of Glory: The Army of the Cumberland, 1861-1865 (Baton Rouge: Louisiana State University Press, 2004), 194. ${ }^{206}$ Ibid., 185.

${ }^{207}$ Patrick A. Lewis, For Slavery and Union: Benjamin Buckner and Kentucky Loyalties in the Civil War (Lexington: University Press of Kentucky, 2015), 100-104. 
impact of the proclamation upon the North as "two-fifths of Union men had a Democratic background and at least one-tenth hailed from a border state."208

Negative protest emerged within the local populations in Kentucky as a result of Lincoln's emancipationist policy and those protests threatened to divide Union soldiers. Some northern units, more sympathetic to both confiscation and emancipation, clashed with pro-slavery Union soldiers and citizens. National headlines captured events such as when a mob of central Kentuckians from Georgetown assaulted a Wisconsin regiment nicknamed "the abolitionist regiment." ${ }^{\text {209 }}$ In Mount Sterling, another central Kentucky town, a tense confrontation occurred between an Illinois regiment and Kentuckians furious at the group for their reputation of being "slave hounds." 210 The event culminated when Union soldiers of the $14^{\text {th }}$ Kentucky Infantry arrived at the scene ready to attack the Illinois troops. The standoff never erupted into a full violent exchange between the two Union regiments, but the situation in central Kentucky displayed a fracturing loyalty due to the nature of the war's new policy toward southern slaves. Historian Michael Rhyne described the violence that engulfed the Bluegrass Region as "less a component of the larger war between the states but rather a blossoming revolution against federal authority." 211 Nonetheless, the Emancipation Proclamation became effective on January 1, 1863—one-hundred days after the September 17, 1862 issuance.

${ }^{208}$ Louis P. Masur, Lincoln's Hundred Days: The Emancipation Proclamation and the War for the Union (Cambridge: The Belknap Press of Harvard University Press, 2012), 133.

${ }^{209}$ Lewis, For Slavery and Union, 98.

${ }^{210}$ Ibid., 98-99.

${ }^{211}$ Michael Rhyne, "A Blood Stained Sin: Slavery, Freedom, and Guerilla Warfare in the Bluegrass Region of Kentucky, 1863-1865," The Register of the Kentucky Historical Society, 112 (Autumn 2014): 560. 
The soldiers who comprised the Army of the Cumberland, many from areas where resistance to Lincoln's war policy was in hot debate, secured one of the war's most important victories in the days surrounding the beginning of southern emancipation.

Outside of Murfreesboro, Tennessee, Stones River resulted in another large battle between the Union and General Bragg's Confederate forces. Union General William Rosecrans reorganized the troops he inherited from the relieved Don Carlos Buell. The corps in Buell's former army took the new names of "the right wing," "the center," and "the left wing" with generals Alexander McCook, George Thomas, and Thomas Crittenden leading the respective three Union corps. ${ }^{212}$ On the morning of December 31, 1862, General Bragg ordered an offensive at the approaching Union Army. The first day of the battle, fought on the final day of 1862, ended with General Philip Sheridan's division holding out against Bragg's assault. From Brigadier General Horatio Van Cleve's division, Union Colonel Samuel Beatty led a brigade comprised of Indiana, Ohio, and Kentucky troops involved in some of the most intense fighting. ${ }^{213}$ By the end of the encounter, Beatty's troops, which included two Kentucky regiments, suffered the heaviest casualties of any Union group at Stones River with nearly fifty percent of the brigade fallen to either death or injury. ${ }^{214}$ Overall, the Murfreesboro battle took shape as a deadly clash of brigades that vied for control of the coveted Nashville Pike and the Nashville and Chattanooga Railroad that ran just behind the road. ${ }^{215}$ General McCook's

${ }^{212}$ Earl J. Hess, The Civil War in the West: Victory and Defeat from the Appalachians to the Mississippi (Chapel Hill: The University of North Carolina Press, 2012), 127.

${ }^{213}$ Hess, The Civil War in the West, 130; Daniel, Days of Glory, 215.

${ }^{214}$ Daniel, Days of Glory, 224.

${ }^{215}$ For more on Stones River see James Lee McDonough's Stones River: Bloody Winter in Tennessee (Knoxville: University of Tennessee Press, 1983) and Larry J. Daniel's Battle of Stones River: The Forgotten Conflict Between the Confederate Army of 
corps, as had happened at the Battle of Perryville, found themselves the most engaged. On January 1 the two armies did not order any significant attacks, but on January 2 Confederate General John C. Breckinridge renewed the offensive and suffered heavy casualties when his divisions marched into a location fortified with Union artillery. Fearful about the number of Union troops that the Confederate Army faced and the potential reinforcements on the way, General Bragg ordered a retreat the following day and looked to reposition the Army of Tennessee further south to Tullahoma. While the losses were high, the Union claimed a strategic victory.

The Army of Cumberland's success at Stones River helped offset Burnside's December 1862 defeat at Fredericksburg and Grant's slow progress with the Mississippi River town of Vicksburg. The battle produced near 23,000 casualties total, and each side sustained over 10,000 soldiers lost to either death, wounds, or capture. A distraught federal executive celebrated the victory as news of defeat to the east and a lack of progress to the west threatened to jeopardize the entire Union war effort. Many believed that a Union defeat in southern Tennessee, alongside the other setbacks, may have brought foreign assistance to the Confederacy. Stones River stood as the only good news to start 1863 and northern newspapers heaped praise on the leadership of General Rosecrans. ${ }^{216}$ Some executives even considered relocating Rosecrans to the Eastern Theatre where he could be used against the momentum of General Lee and the Army of Northern Virginia. President Lincoln summarized the significance of the Tennessee

Tennessee and the Union Army of the Cumberland (Baton Rouge: Louisiana State University Press, 2012).

${ }^{216}$ James McPherson, Battle Cry of Freedom: The Civil War Era (New York: Oxford University Press, 1988), 582-83. 
encounter months later when he addressed the Army of the Cumberland's efforts as perhaps saving the nation. ${ }^{217}$

II.

In the very same week Kentucky's Union soldiers made advances into Tennessee as either part of the small band who aided General Carter's expeditionary force or as enlistees who served in General Rosecrans's much larger three corps within the Army of the Cumberland, Confederate raiders made a destructive ride through the western portion of the state under the direction of John Hunt Morgan. The raiders took a route north out of Tennessee like General Bragg's summer invasion and crossed into Kentucky on December 24, 1862. The Confederates made it to Glasgow, Kentucky on Christmas, traveled through Munfordville where they defeated a small garrison, and went on to capture six-hundred Union men near Elizabethtown, Kentucky. ${ }^{218}$ Historian Christopher Phillips assessed:

Heavy cavalry raids offered many residents their first glimpse of regular Confederates since their armies had been forced south. Home guards fled, useless against such numbers, and raiders tore up railroad lines, destroyed bridges and depots, and entered communities. For many southerners these horsemen were bold cavaliers ... But boasts of chivalry for these horsemen obfuscated a war they were already experiencing in the West that was anything but noble. ${ }^{219}$

One of the primary goals of Morgan's raids was to cut a major Union supply line that supported Rosecrans's army. The raids caught the attention of Union Generals Horatio Wright in Cincinnati and Jeremiah Boyle in central Kentucky as the two strategized in

${ }^{217}$ Hess, The Civil War in the West, 133.

${ }^{218}$ Lowell H. Harrison, The Civil War in Kentucky (Lexington: The University Press of Kentucky, 1975), 60-62.

${ }^{219}$ Cristopher Phillips, The Rivers Ran Backwards: The Civil War and the Remaking of the American Middle Border (New York: Oxford University Press, 2016), 203. 
tandem to keep the railroads in Kentucky operating and safe from Confederate harm.

Central Kentucky Home Guards scrambled to protect the vital infrastructure as the railroads delivered a steady supply of food for Rosecrans's army during their operations in Tennessee. ${ }^{220}$ The Confederate Morgan made his escape through Campbellsville, then Columbia, and finally Burkesville before reentering Tennessee. And while General Bragg's Army of Tennessee continued to take a defensive position at Tullahoma and General Lee's Army of Northern Virginia planned an offensive into Pennsylvania, Kentucky experienced numerous more raids and smaller invasions throughout the first half of 1863.

The direct path of Morgan's “Christmas Raid” spared southeastern Kentucky. But just before spring 1863, violence and theft at the hands of those who supported the Confederacy engulfed most of the state. Colonel Roy S. Cluke and 750 of his Confederate $8^{\text {th }}$ Kentucky Calvary crossed the Cumberland River in mid-February to foray through the Bluegrass, Confederate General John Pegram's troops captured Danville on March 24, and General Humphrey Marshall's cavalry attacked a Union garrison at Louisa in the northeastern portion of that state during the closing weeks of March. The war had changed. It was in Louisa, late 1861, that James A. Garfield met his Ohio troops to first assume command with the order not to steal from local citizens and declared that he would lead a "regiment of gentlemen." 221 Confederate commanders

\footnotetext{
${ }^{220}$ Harrison, The Civil War in Kentucky, 63.

${ }^{221}$ Gerald F. Linderman, Embattled Courage: The Experience of Combat in the American Civil War (New York: The Free Press, 1987), 183. For more on Garfield's early experiences in Kentucky and how they shaped his outlook, see Candice Millard's popular account Destiny of the Republic: A Tale of Madness, Medicine, and the Murder of a President (New York: Anchor Books, 2012), 24-27.
} 
issued similar demands in the early part of the war. But the southern raiders, frustrated by failed invasions and the inability to bring Kentucky into its fold, abandoned careful behavior that courted loyalty for more aggressive measures. By April, some of Marshall's men made it into southeastern Kentucky. Frances Peters recorded the news in an April 18 entry into her diary:

... 'Thursday' says the Observer, 'Mr. A.B. Gilbert of Owsley County, former member of [the] Legislature, was at our office and gave a sad account of the district in which he resides.' Cluke's men robbed him of grain and stock some weeks ago and on Wednesday of last week some of Marshall's men under Jack May came to his house [and] in his absence appropriated 33 blankets and other articles. [They] took all the horses and robbed the bee hives, and though his wife offered them a thousand dollars not to do it, burnt two dwelling houses [,] a store house and granery, [sic] not permitting Mrs. Gilbert to save any clothes or anything but a bed from the flames.... The rebels burnt the jail at Booneville [in] Owsley County and fired the Court house, but the latter was saved by the citizens, but the records and papers of the Circuit and County Court were destroyed. They were torn up and scattered in the streets. And these same men of Marshall's in passing through Wolf [sic] County burned forty three houses. ... ${ }^{222}$

Colonel Samuel Gilbert of the $44^{\text {th }}$ Ohio Infantry delivered a May 12 report from London,

Kentucky to Lexington that relayed a similar story. The $44^{\text {th }}$ Ohio pursued three-hundred

Confederates southeast of Manchester near Red Bird River. Gilbert reported:

They [the Confederates] fled at the first fire. Captain Moore pursued for several miles, and captured some small-arms and other plunder, but his horses were not fresh enough to catch them. He reports several wounded. He reports that they have been stripping the citizens of not only horses and provisions, but even of their clothing, and that they had put some to torture to make them tell where their horses and arms were hid. ${ }^{223}$

${ }^{222}$ A Union Woman in Civil War Kentucky: The Diary of Frances Peters, ed. John David Smith and William Cooper Jr. (Lexington: The University Press of Kentucky, 2000), 123. 223 "Report of Samuel A. Gilbert," May 12, 1863, United States War Department, The War of the Rebellion: A Compilation of the Official Records of the Union and Confederate Armies (Washington D.C.: Government Printing Office, 1880-1901), Series.1, Vol. 23, Part I, 310. 
While citizens in the Bluegrass Region of the state exhibited an angst against federal authority, many Kentuckians, according to Christopher Phillips, determined that "the hard treatment at the hands of rebel horsemen crushed the illusion of the superiority of the South and its culture."224 The Confederate pillaging brought a Union presence. Union Colonels John Marshall Harlan and Frank Wolford chased John Hunt Morgan, and other Confederate bands, around the Bluegrass portions of the state. Union Generals Mahlon D. Manson and Samuel Carter worked together to disrupt Confederate activity in the southern part of the state. During the months of April and May 1863, General Carter's men encountered guerillas and other organized Confederates near Somerset. Carter identified a network of Confederates that stretched back into the southeastern section of Kentucky. In an April 29 message to Brigadier General O.B. Wilcox, General Carter reported to have encountered a regiment of 900 enemy soldiers from a Georgia cavalry supported by a Confederate infantry in Livingston, Kentucky. ${ }^{225}$ Not only was the area in the middle of armed conflict, but the communities caught between the opposing forces suffered through the impact with the loss of local resources. General Carter concluded his cavalry could not be foraged in his current location and added that "the country is stripped."226 After his disastrous defeat in northern Virginia, Union leadership relocated General Ambrose Burnside to Kentucky to aid in the repulse of the increased guerilla activity. As Confederates continued to probe portions of Kentucky for

\footnotetext{
${ }^{224}$ Phillips, The Rivers Ran Backwards, 205.

225 "Report of Samuel P. Carter," April 29, 1863, United States War Department, The War of the Rebellion: A Compilation of the Official Records of the Union and Confederate Armies (Washington D.C.: Government Printing Office, 1880-1901), Series.1, Vol. 23, Part I, 309.

226 Ibid.
} 
resources and support, another larger invasion was not out of the question. Historian

Allen Guelzo analyzed the situation Confederates faced in early 1863:

Three times, a Confederate field army tried to recover the lost territory in Tennessee and Kentucky, in battles at Shiloh, Perryville, and

Murfreesboro. All three times it failed, and now the Confederacy was left barely clinging to the southeast corner of Tennessee, while a Union army was fastening its grip on Vicksburg. ${ }^{227}$

Guelzo added how that Lee, in preparation to his offensive into Pennsylvania, lobbied

Richmond for another joint invasion like the 1862 push into both Maryland and

Kentucky:

This was the moment, Lee politely suggested, for Joe Johnston to take the Confederate armies in the West on the offensive, and magnify the pressure on the Lincoln government by invading Kentucky, perhaps even Ohio. ${ }^{228}$

The Union's defense in Kentucky against Morgan's raids, and the resistance to the broader Confederate efforts that surrounded those raids, may have been just enough to deter Jefferson Davis from following Lee's suggestions. The Union's renewed attention to the area made a difference as well. In a May 1 report, a Confederate cavalry officer believed that General Burnside was near Crab Orchard with an army of " 15,000 to 20,000 men, the extreme advance of which is known to be at Williamsburg and London, Kentucky."229 While Confederates often overestimated or misplaced the enemy presence in some instances, in other parts of the state the Union continued to initiate important operations that hindered the South's overall plans.

${ }^{227}$ Allen C. Guelzo, Gettysburg: The Last Invasion (New York: Vintage Books, 2013), 32.

228 Ibid., 75.

229 "Report of Captain A.L. Mims," May 1, 1863, United States War Department, The War of the Rebellion: A Compilation of the Official Records of the Union and Confederate Armies (Washington D.C.: Government Printing Office, 1880-1901), Series.1, Vol. 23, Part I, 321. 
Another expedition took regiments made up of Kentuckians into Confederate controlled areas. In early July 1863 a group that included detachments from the $39^{\text {th }}$ Kentucky Infantry, the $65^{\text {th }}$ Illinois Infantry, the $10^{\text {th }}$ Kentucky Cavalry, the $14^{\text {th }}$ Kentucky Infantry, and one squadron of Ohio volunteer cavalry infiltrated Virginia at Beaver Creek located near Pikeville. The unit consisted of just under one-thousand men and crossed into Virginia through Pound's Gap to target another railroad juncture - this time at Bristol. Once in southwestern Virginia, the Union force skirmished with Confederates where they captured one-hundred men and destroyed a cache of military supplies. After the victory, Brigadier General Julius White split his troops and sent a detachment of the $39^{\text {th }}$ Kentucky and the $65^{\text {th }}$ Illinois to Tug Fork, located in West Virginia, to engage a separate group of Confederates. West Virginia had become a state on June 20, 1863, only two weeks before the encounter. Under Union Colonel Dan Cameron the detachment managed to defeat the Confederates. In communication to Burnside, White relayed the news:

Since my last dispatch, a detachment of the Sixty-fifth Illinois and Thirtyninth Kentucky, from this command, under Col. Dan Cameron, have returned from an expedition up the Tug River into West Virginia, where they routed and dispersed the enemy, under Buchanan, killing 5 and capturing 20. The enemy took to the cliffs and mountain sides, but the brave Illinoisans and Kentuckians vied with each other in climbing the steeps under a galling fire, and driving the enemy from their mountain fastnesses. Colonel Cameron and his officers and men have exhibited the utmost daring and energy, and have penetrated where no Union troops have been before. ${ }^{230}$

230 "Brigadier-General Julius White to Major General Ambrose Burnside," July 10 \& 11, 1863, United States War Department, The War of the Rebellion: A Compilation of the Official Records of the Union and Confederate Armies (Washington D.C.: Government Printing Office, 1880-1901), Series.1, Vol. 23, Part I, 818-819. 
The event is evidence of the broader organization and scope of operations supporting General Burnside's defense of Kentucky. In addition, the engagement at Tug Fork included the $39^{\text {th }}$ Kentucky Infantry—a unit comprised of several Appalachian Kentuckians from the far eastern portion of the state-fighting alongside Illinoisans to advance Union goals in a newly formed state with another population loyal to the Union. The soldiers in groups such as these played a small role as part a larger effort to protect Union objectives. In the following months, West Virginia adopted a state seal that featured the Latin phrase Montani Semper Liberi-"Mountaineers are Always Free.”

During the summer days of 1863 when Union troops guarded Kentucky against guerillas and infiltrated Confederate forces across state lines, the nation received news about two of the most important victories of the war that took place at Gettysburg, Pennsylvania and at Vicksburg, Mississippi. Skirmishes in the southeastern portion of Kentucky continued throughout the same month as those monumental victories. On July 26, Union troops skirmished with Confederates in London, at Irvine on July 30, Lancaster and Stanford on July 31. As General Burnside pushed south, Eastern Tennessee remained anxious and citizens petitioned both Lincoln and Secretary of War Edwin Stanton to redeem their area of the state. President Lincoln responded to the petitioners in early August with the assurance that he was doing as much for East Tennessee as if his immediate family were there and that Secretary Stanton, General Halleck, General Burnside, and General Rosecrans were all engaged to relieve them. ${ }^{231}$ A month after Lincoln's promise of a Union effort to help East Tennessee, General Burnside arrived in

${ }^{231}$ Richard Nelson Current, Lincoln's Loyalists: Union Soldiers from the Confederacy (New York: Oxford University Press, 1992), 51-52. 
Knoxville with the Army of the Ohio, 24,000 troops strong, and occupied the city on

September 3 with little resistance. ${ }^{232}$ The Confederate troops evacuated south to join

Bragg's Army of Tennessee in northern Georgia.

President Lincoln pressed General Rosecrans to make an offensive thrust on the Confederates collected in southern Tennessee and northern Georgia. Since the Battle of Stones River, resignations continued to plague the Army of the Cumberland as Rosecrans had lost additional Kentuckians in protested fallout to the Emancipation Proclamation.

Historian Victor Howard accessed:

Soon after the Battle of Stones River, December 31,1862, some fifteen or eighteen officers of the Fifteenth Kentucky Infantry tendered their resignation without giving any special reason. All were sent back by Gen. Richard W. Johnson, who commanded the division. Within a few days some half-dozen or more of the same officers again sent in their resignations without stating a reason, and again were turned down. . . .Colonel Cochran and other officers of the Fourteenth Infantry resigned because of the president's proclamation. More than a hundred men deserted the Twenty-fourth infantry ... Many of the Kentucky regiments under Rosecrans were so depleted of forces that there was talk of combining some of them....As the epidemic of resignations spread through Kentucky troops, Col. J.H. Ward, commander of the Twentyseventh Regiment, issued an order reminding his men that it was their duty "as soldiers to suffer anything, even unto death," as long as there was at least hope of establishing the Constitution and perpetuating the Union. ${ }^{233}$

McCook's corps is where many of the Kentucky soldiers and officers, disgruntled at emancipation, served. General McCook, himself, expressed an open opposition to Lincoln's approach. ${ }^{234}$ Going into the Battle of Chickamauga, Union command reorganized the Army of the Cumberland again and placed many of the Kentucky

${ }^{232}$ McPherson, Battle Cry of Freedom: The Civil War Era, 670.

${ }^{233}$ Victor Howard, Black Liberation in Kentucky: Emancipation and Freedom, $1862-$ 1884 (Lexington: University Press of Kentucky, 1983), 33-34.

${ }^{234}$ Daniels, Days of Glory, 194. 
regiments under either General Thomas's XIV Corps or General Crittenden's XXI Corps. Rosecrans's army added a cavalry corps that pushed his total number to around 56,000 men. As he pursued Bragg's army into northern Georgia, Chickamauga Creek emerged as the location the Confederates chose to push back. Named from a Cherokee word that translated into "River of Death," Chickamauga developed into one of the deadliest battles for the Army of the Cumberland. ${ }^{235}$ The mid-September encounter lasted two days and produced over 16,000 Union casualties. Rosecrans made mistakes and all his corps, except General Thomas's, experienced near annihilation. The $3^{\text {rd }}$ Kentucky Infantry, made up of soldiers from the earliest 1861 calls for Kentucky volunteers, along with three Ohio regiments, played a key role in helping to save Crittenden's corps. Forced to retreat, Chickamauga represented a low point for the Army of Cumberland and the battle's Union hero, General George Thomas, soon replaced General Rosecrans.

Union troops retreated to Chattanooga to regroup after the Chickamauga disaster. In the two months before the next major engagement, Union leadership made more changes to the command structure in the Western Theatre of the war. After General Grant's success in his siege of Vicksburg, the executive administration placed him in charge of all Western Armies in October 1863. Grant soon thereafter communicated his concerns to Secretary of War Edwin Stanton about General Rosecrans's lack of ability to follow his orders and selected George H. Thomas to command the Army of the Cumberland. ${ }^{236}$ Thomas's actions at Mill Springs, Stones River, and Chickamauga helped elevate him to the position. By mid-November, Grant also had moved General

235 Allen Guelzo, Fateful Lightning: A New History of the Civil War and Reconstruction (New York: Oxford University Press, 2012), 352.

${ }^{236}$ Daniels, Days of Glory, 351-354. 
William T. Sherman's Army of the Tennessee into Chattanooga to defend against Bragg's attempt to force the Union north.

General Bragg looked to dislodge the northern armies from Chattanooga and established a strong position that held various high points, which included Lookout Mountain and Missionary Ridge that overlooked the Union position. On November 23 General Grant ordered an attack on the elevated Confederate locations. The Battle of Chattanooga, with over 120,000 troops engaged between the two opposing sides, lasted for three days and provided the Union with another important victory. On the morning of the final day of fighting, the $8^{\text {th }}$ Kentucky Regiment from the Army of the Cumberland, under General Charles Cruft's division, volunteered to scale Lookout Mountain. Colonel Barnes formed the Kentucky regiment in 1861 and recruited men from Estill, Jackson, and Owsley Counties. When Colonel Barnes asked for a squadron to check the summit for a Confederate presence, a few soldiers expressed eagerness at the opportunity. Peter Cozzens summarized the moment:

Captain John Wilson, commander of the color company, jumped up and begged to be allowed the honor. Barnes granted this request. Wilson turned to the color-bearer and asked him to follow with the flag. The bearer hesitated, glanced at the hundred-foot wall of rock and contemplating the weight of the flagstaff. Wilson grabbed the flag and handed the reluctant sergeant his sword. Six enlisted men volunteered to join Wilson. Gripping with one hand a long wild grapevine that dangled from the summit, Wilson started up the natural stairway of broken rock. His Kentuckians followed him. They clutched at rocks and bushes, grasped limbs and vines, and shoved one another upward. ${ }^{237}$

Once Wilson reached the top, he unfurled the American flag from a vantage point that caught the Union Army's attention from many points below. The rest of the $8^{\text {th }}$ Kentucky

${ }^{237}$ Peter Cozzens, The Shipwreck of Their Hopes: The Battles for Chattanooga (Urbana: University of Illinois Press, 1994), 201-202. 
soon followed to Wilson's position in a skirmish line and only encountered a few Confederates. General Cruft was "delighted at his boys' daring." ${ }^{238}$ The moment did little to affect the overall outcome of the larger battle, but Wilson's actions, along with the $8^{\text {th }}$ Kentucky Regiment, provided a momentary boost in morale for many Union soldiers at Chattanooga and the success formed a sense of pride in the Kentucky regiment that carried over into the years well after the war.

The clearing of Confederates from Chattanooga started a new phase of the war as the beginning stages of Sherman's "March to the Sea" unfolded in the aftermath of Bragg's defeat. Many of the Union Kentucky soldiers in the Western Theatre of the war soon found themselves at locations such as Kennesaw Mountain, Atlanta, and other locations on the way to Savannah. President Lincoln called General Grant to Washington. Prior to going to the nation's capital, General Grant passed through Southeastern Kentucky and lodged at the foot of Big Hill, less than a mile from Jackson County's northern boundary. Grant wrote of the experience in his memoirs:

It was an intensely cold winter, the thermometer being down as low as zero every morning for more than a week while I was at Knoxville and on my way from there on horseback to Lexington, Kentucky.... The road over Cumberland Gap, and back of it, was strewn with debris of broken wagons and dead animals, much as I had found it on my first trip to Chattanooga over Waldron's Ridge. The road had been cut up to as great a depth as clay could be by mules and wagons, and in that condition frozen; so that the six days from Strawberry Plains to Lexington over these holes and knobs in the road was a very cheerless one, and very disagreeable. I found a great many people at home along that route, both in Tennessee and Kentucky, and, almost universally, intensely loyal. They would collect in little places where we would stop of evenings to see me, generally hearing of my approach before arriving. ${ }^{239}$

\footnotetext{
238 Ibid., 202.

${ }^{239}$ The Annotated Memoirs of Ulysses S. Grant ed. Elizabeth D. Samet (New York: Liveright of W.W. \& Norton Publishing, 2018), 579.
} 
III.

The course of the war shifted in the Union's favor following the federal successes at Gettysburg and Vicksburg in the summer of 1863, along with fall events at the Tennessee and Georgia line, as the country entered 1864. But for Kentucky, guerrilla activity continued across the Commonwealth. The state's loyalty remained endangered as splits over emancipation and federal policy threatened to alter the allegiance of many residents within the army and at home. This situation, combined with the swaths of population already sympathetic to the Confederate cause since the war's outset, produced an environment difficult to control.

The appointment of General Stephen G. Burbridge to monitor potential threats, and to bring order to areas affected by Confederate defiance, produced mixed results. Governor Thomas E. Bramlette welcomed the news of Burbridge's assignment to his troubled state. ${ }^{240}$ A native-born Kentucky farmer from Logan County, General Burbridge took over in Kentucky in February 1864. Louis De Falaise described the general's inherited situation:

The most serious problem facing Burbridge as he took his new command was that of guerilla marauding. As a border state, Kentucky harbored many with Southern proclivities. The guerillas were of two types. First, there were detached units of the Southern army. Secondly, there were brigands, native Kentuckians and deserters from the Southern army, who were using the war as an excuse for looting. ${ }^{241}$

Just prior to Burbridge's new authority on these matters, an officer from the $45^{\text {th }}$

Kentucky filed a report where the group encountered a band of guerillas attempting to hang a Union sympathizer and Governor Bramlette had already issued an order that

${ }^{240}$ Louis De Falaise, “General Stephen Gano Burbridge's Command in Kentucky," The Register of the Kentucky Historical Society, 69 (April 1971): 103.

241 Ibid. 
directed military authorities to arrest five Confederate sympathizers in every area where a Union man was targeted. ${ }^{242}$ But as Burbridge raised the hopes of Governor Bramlette's desire to calm Kentucky of guerilla violence, he also emerged as a federal extension of the new policies of the war. High-ranking officials started to issue directives to Burbridge. General Sherman ordered the execution of guerillas who interfered with steamboat supplies, Judge Advocate Joseph Holt recommended the most severe punishment of southerners who broke parole, and the most divisive issue — what to do with the impressment and enlistment of African Americans for the war effort-also fell on Burbridge's authority. ${ }^{243}$

John Hunt Morgan's 1864 raid into Kentucky accelerated the state's problems. By late-May, the Confederate raider left Virginia and made entry into Kentucky from the southeast. Morgan's raid targeted Mt. Sterling, Lexington, and Cynthiana. The 1864 raid brought Morgan's raiders into contact with several southeastern Kentuckians who had just mustered in with the $47^{\text {th }}$ and $49^{\text {th }}$ Kentucky Volunteer Infantries. The Union Army stationed the $47^{\text {th }}$ and $49^{\text {th }}$ at Camp Nelson under Brigadier General Speed S. Fry to protect the training of African-American troops. ${ }^{244}$ The $40^{\text {th }}$ and $45^{\text {th }}$ Kentucky Infantries

\footnotetext{
${ }^{242}$ Ibid., 104.

${ }^{243}$ Ibid., 106-107.

${ }^{244}$ For more on Camp Nelson see Richard Sears, "John G. Fee, Camp Nelson, and Kentucky Blacks, 1864-1865," The Register of the Kentucky Historical Society, 85 (Winter 1987): 29-45 and Richard Sears, Camp Nelson, Kentucky: A Civil War History (Lexington: University Press of Kentucky, 2002). Sears explores several issues that arise from the training of African-American troops in central Kentucky, including disputes between General Fry and General Burbidge on the purpose of the camp and the treatment of refugees.
} 
were also active against Morgan's men and many of the Kentucky units responsible for defending against the raids came from the fall 1863 call for recruits.

Murders and harassment of southeastern Kentuckians resulted from the Confederate foray into the state. As colonel in command of the $47^{\text {th }}$ Kentucky Infantry, Andrew H. Clark received news of the murder of his father who lived in Booneville, Owsley County. Confederate Colonel Henry Giltner's men, including Giltner's own son, tortured and murdered William Clark. The Lexington National Unionist reported a story in the days that followed about a 101-year-old Baptist preacher in Clay County named John Gilbert. The newspaper claimed that the same Confederate band who killed Clark also stole Gilbert's money, all his horses, and all his food. ${ }^{245}$ A Union veteran of the $7^{\text {th }}$ Kentucky Regiment, Elihu Webber experienced a similar fate. Confederate guerillas robbed Webber of all his money and clothing as he returned home to Owsley County from three years of service. ${ }^{246}$ Numerous veterans from the $7^{\text {th }}$ Kentucky Regiment filed a petition to Governor Bramlette to have Webber pardoned for a twenty-five dollar fine as the robbery left him "destitute of everything in the clothing line and money." 247 Residents in the upper counties of Tennessee sent a petition to General Samuel Carter in hopes that the general might use his influence in an appeal for help. The request read:

As the harvest is now fast approaching and no help to reap or take care of the grain, and there being little corn planted this spring, in God's name, what will the people of that section do, should they receive no aid from the Federal Government, and the rebels are permitted to reap and take what

${ }^{245}$ The National Unionist, June 28, 1864.

246 “G. W. Daniel et al. to Thomas E. Bramlette,” n.d., Office of the Governor, Thomas E. Bramlette: Governor's official correspondence file, petitions for pardons, remissions, and respites 1863-1867, BR12-74 to BR12-75, Kentucky Department for Libraries and Archives, Frankfort, KY. Accessed via the Civil War Governors of Kentucky Digital Documentary Edition, discovery.civilwargovernors.org/document/KYR-0001-004-1337. ${ }^{247}$ Ibid. 
grain is now growing? What will become of the mothers, wives, sisters, and children of the many soldiers and refugees that are now away from home? ....Letters are received here daily from those loyal women who still remain at home, almost heartbroken, praying that the Federals may send them protection and relieve them of their awful sufferings. . . Believing, as we do, in the Christian people of the United States, they will, they must, soon give us aid and relief. ${ }^{248}$

Over three hundred citizens signed the petition and the message echoed the desperation of the area. Under the command of General Burbridge, soldiers from the $37^{\text {th }}$ and $39^{\text {th }}$ Kentucky Regiments joined in and helped defeat Morgan at the Second Battle of Cynthiana. The battle occurred over June 11 and 12 and produced over 2,000 combined casualties for the two sides. The battle represented an endpoint for Morgan's final raid, Morgan escaped back to Abingdon, Virginia. ${ }^{249}$ But like his earlier raids, the fallout and increase in violent activity remained in Kentucky.

A series of controversial federal orders followed the May and June violence. On July 16, 1864, General Burbridge issued General Order Number 59. The order adopted stringent measures to protect against "the plundering and murdering [of] peaceful Union citizens." 250 The order called for the arrest of five rebel sympathizers living within a five-mile radius for every one Union citizen targeted. Furthermore, the federal government promised to confiscate property in equal value from the perpetrators, and if a murder was involved, authorities were directed to publicly execute four Confederate

248 "William H. Briant, et al to General Samuel Carter," May 28, 1864, United States War Department, The War of the Rebellion: A Compilation of the Official Records of the Union and Confederate Armies (Washington D.C.: Government Printing Office, 18801901), Series.1, Vol. 39, Part II, 75-76.

${ }^{249}$ Harrison, The Civil War in Kentucky, 74.

250 “General Orders No. 59," July 16, 1864, United States War Department, The War of the Rebellion: A Compilation of the Official Records of the Union and Confederate Armies (Washington D.C.: Government Printing Office, 1880-1901), Series.1, Vol. 39, Part II, 174. 
sympathizers. ${ }^{251}$ Accompanying the announcement of Burbridge's new policy, President Lincoln issued General Order Number 233 that amounted to "a proclamation to suspend the writ of habeas corpus, and establish martial law in Kentucky." ${ }^{252}$ In a July letter from the Judge Advocate Holt to Secretary of War Stanton, Holt relayed that, "Kentucky has been for some time and is still in a deplorable condition. A very large part of the State is completely overrun with guerillas, who plunder farm-houses, and fields, and villages at will, and often murder the helpless victims of their robberies." ${ }^{253}$ Much of Holt's concern revolved around Lincoln's amnesty proclamation meant to quell Confederate behavior with the administration of an oath of loyalty. Holt expressed his belief that guerillas manipulated the proclamation and oaths to avoid punishment. In the letter, Holt communicated his frustrations of prominent politicians defiant to the recruitment of black regiments. Holt advanced a theory that "a large number of influential men in Kentucky, embracing several occupying the highest positions under the State government, are found to be members and officers of this association or conspiracy." ${ }^{254}$

Divisions over federal policy swept the state. Many Kentuckians, sympathetic to Confederate causes, expressed outrage at Burbridge's approach to justice. Leaders in Kentucky followed suit. General Burbridge admonished General Speed Fry for his

${ }^{251}$ Ibid.

252“"General Orders No. 233 from the War Department," July 19, 1864, United States War Department, The War of the Rebellion: A Compilation of the Official Records of the Union and Confederate Armies (Washington D.C.: Government Printing Office, 18801901), Series.1, Vol. 39, Part II, 180-182.

253 “Joseph Holt to Edwin Stanton," July 31, 1864, United States War Department, The War of the Rebellion: A Compilation of the Official Records of the Union and Confederate Armies (Washington D.C.: Government Printing Office, 1880-1901), Series.1, Vol. 39, Part II, 212-215. ${ }^{254}$ Ibid., 214. 
treatment of black refugees at Camp Nelson. Officials had already arrested and removed Union Cavalry Colonel Frank Wolford for a speech critical of Lincoln and the use of black regiments. Even Governor Bramlette, who had welcomed Burbridge's appointment, started to warn that federal policies were driving the state into the Confederacy. At the federal level, Kentucky Senator Garrett Davis had "begun the year with a flurry of resolutions condemning the war measures of the Lincoln administration and in turn faced the threat of expulsion from that August body."255

Residents in the southeastern portion of the state did not express the level of resistance as did their counterparts around the state. As central Kentuckians took a firm political stand against federal policy, many residents of Appalachia either did not hold that sentiment or chose not to rebel against the authorities offering them protection in any significant number. The $47^{\text {th }}$ and $49^{\text {th }}$ Kentucky Regiments continued to guard Camp Nelson under new military leadership. As a preacher of racially mixed ancestry in Jackson County who pastored at South Fork Baptist Church, John Drew left his congregation to answer Reverend John Fee's 1864 August request to aid in the educational efforts with African-Americans at Camp Nelson. ${ }^{256}$

In the Presidential election of 1864 - an election where Confederate States did not participate - Lincoln defeated former General George McClellan. The electoral tally resulted in 212 votes for Lincoln and 21 votes for McClellan. Lincoln carried all states except for New Jersey, Delaware, and Kentucky—with Kentucky handing Lincoln his worst popular vote performance in the country. ${ }^{257}$ Within Southeastern Kentucky,

${ }^{255}$ Rhyne, “A Blood Stained Sin," 572.

${ }^{256}$ Sears, Camp Nelson, 98.

${ }^{257}$ McPherson, Battle Cry of Freedom, 804-805. 
however, nine counties returned results in favor of President Lincoln. In Harlan County, Lincoln captured more than $80 \%$ of the vote, in Jackson and Whitley Counties, the total topped over $90 \% .{ }^{258}$ Nine other Kentucky counties cast the fewest popular votes for Lincoln in a category that measured the bottom twenty in the nation. Spencer, Meade, and Clinton Counties returned less than five popular votes each for President Lincoln's reelection. ${ }^{259}$

Enlistments is another area where historians can measure the negative federal impact in the post-emancipation phase of the war. In 1909, the Secretary of War released Kentucky statistics from the 1864 draft. $^{260}$ The release was in response to a United States Senate Resolution looking to clarify the number of draftees from the various districts in Kentucky. A preliminary draft occurred in March and a second draft followed on July 18, 1864. In April 1864, the War Department adjusted the quotas, based on a combination of population and men still in military service, required from each district. The 1909 legislation was in effort to determine if claimants paid too much money for substitutes or for commutations. Inside those numbers, however, the report revealed that most of the districts operated on deficiencies when it came to the number of troops provided. Of the nine districts, only three provided a number of soldiers that surpassed

\footnotetext{
${ }^{258}$ For a county by county breakdown of presidential elections see Presidential Elections, 1789-2008: County, State, and National Mapping of Election Data ed. Donald R. Deskin, Hanes Walton, and Sherman C. Puckett (Ann Arbor: The University of Michigan Press, 2010), 178.

${ }^{259}$ Ibid.

${ }^{260}$ Drafts in Kentucky During Civil War, A Letter from the Secretary of War, In Response to Senate Resolution Number 63, by Mr. Bradley, of July 2, 1909, A Letter from the Adjutant-General of the Army Setting Forth Such Information as it is Possible to Furnish Concerning the Drafts in the State of Kentucky during the Civil War. Document 142, 61 ${ }^{\text {st }}$ Congress, $1^{\text {st }}$ Session (Congressional Record), 1909, 1-14.
} 
the quota the War Department set forth. The eighth district, comprised of counties from the southeastern portion of Kentucky, accounted for the most "credits" in the entire state. ${ }^{261}$ Pulaski, Estill, Owsley, Clay, and Jackson Counties combined to have a 1,235 surplus of soldiers. In comparison, in the central Kentucky counties of Fayette, Scott, Clark, Bourbon, and Nicholas Counties, a 1,033 deficiency of soldiers existed. ${ }^{262}$ The final recapitulation of the state quota revealed that the War Department set Kentucky a quota of 80,611 soldiers of which the Commonwealth provided $72,099 .{ }^{263}$ The ProvostMarshall-General also produced records that revealed over 7,000 either paid substitutes or commutation money. ${ }^{264}$ One might conclude that many of those payments did not come from the Appalachian counties.

As the war entered its final months, the guerilla war did not wane. Even with John Hunt Morgan’ death at Greeneville, Tennessee, in September 1864, new raiders arrived in the state to fill the void and new troubles emerged from the Kentucky population. Dubious individuals such as Sue Mundy and William Quantrill brought a new terror to the state. J. Michael Rhyne summarized:

On the surface, this guerilla war appeared to be centered on the activities of well-known Confederate Kentuckians such as John Hunt Morgan or George M. Jesse. But beneath this veneer, a much more personal war erupted as Kentuckians took up arms not only for the Confederacy but also against a federal government seemingly intent on destroying the institution of slavery, not just in the Confederacy but also in the states that had not seceded. $^{265}$

\footnotetext{
261 Ibid, 14.

${ }^{262}$ Ibid., 10-14

263 Ibid., 14

${ }^{264}$ Ibid., 5

${ }^{265}$ Rhyne, “A Blood Stained Sin,” 585.
} 
Determining what drove the sentiments of Southeastern Kentuckians is difficult. But many continued in military service. Reactions to the violence and plunder to the Unionist population may have solidified the political and military loyalty in the region as much as any other factor. One group that captured that spirit arose in the Three Forks Battalion of Kentucky State Troops. As a captain in charge of the battalion, Elisha Treadway hailed as the former sheriff of Owsley County. Treadway had also served in the MexicanAmerican War with the $3^{\text {rd }}$ Kentucky and joined the $7^{\text {th }}$ Kentucky in September $1861 .{ }^{266}$ Seven companies formed the battalion, and the group posted in areas from where the unit recruited—Breathitt, Estill, Owsley, Perry, and Harlan Counties. ${ }^{267}$ In a July 1865 appeal to Governor Bramlette, Treadway requested that the Three Forks Battalion be allowed to continue their work. Treadway wrote:

I am at this place with Six companies of My Battolion [sic], preparing to be mustered out, of the State service, I have two more companies on their way from the Counties of Harlan, and Perry, making Eight in all, I would verry [sic] Respectfully recommend that three of those companies be retained in the State Service, Some two or three Months longer, from the fact, we have not yet established Civil Courts or even yet put down all the guerrillas in the counties of Harlan, Perry, Breathitt, Letcher , \&c. there are reported to be three Bands of guerrillas in those counties ... I would ernestly [sic] recommend that you come to this place next Monday if it be Possible so to do the Citizens generally expect you, if you could be here on that day and address the citizens of this county, and my Battolion [sic], (which represents all Eastern Kentucky) I think it would do more for our cause than anything that could be done in this part of the State. ${ }^{268}$

266 "Elisha B. Treadway" in the Civil War Governors of Kentucky Digital Documentary Edition, discovery.civilwargovernors.org/document/N00002436, (accessed October 27, 2019).

${ }^{267}$ Charles C. Wells, 1890 Special Veterans Census for Eastern Kentucky (Baltimore: Gateway Press, 2000), 278.

268 “E. B. Treadway to Thomas E. Bramlette," 14 July 1865, Active Militia Records Capital Guards, North Cumberland Btn., and Three Forks Btn., Box 77, Folder 865 THREE FORKS BN KSG "OFFICER CORRESPONDENCE", Kentucky Department of Military Affairs, Frankfort, KY. Accessed via the Civil War Governors of Kentucky 
Historians often overlook Kentucky's role and experiences from the second half of the Civil War. After the Confederate retreat following the Battle of Perryville, through the southern armies' final surrender, Kentucky played a role in national developments and they experienced a tumultuous period within the state. Kentucky soldiers fought on each side of the affair, but a far larger number in military service wore Union blue. Some Union regiments helped make up the large armies of the Western Theatre that brought the war to an end. Others who served in Kentucky as Home Guards or in Union detachments protected resources, maintained transportation routes, and guarded camps where AfricanAmericans trained as soldiers. Federal policies related to conscription and emancipation nearly tore the Commonwealth apart. During that test, the Appalachian portions of the state experienced an uptick in the raids and plunder that a split population invited. In the end, the loyalty of the area hardened at the ballot box and through the continued enlistment of soldiers. As some portions of Kentucky started to identify with the Confederate cause or to revolt against federal authority, evidence suggests that the Appalachian region of Kentucky provided a counterweight, if only a small counterweight, to that movement.

Digital Documentary Edition, discovery.civilwargovernors.org/document/KYR-0002060-0024. 


\section{CHAPTER FIVE \\ THE MYSTIC CHORDS OF MEMORY: VOTING PATTERNS, WAR MEMORY, AND ATTACKS ON THE MOUNTAINEER IMAGE}

Historians have elevated Kentucky's significant role in the Union cause with Abraham Lincoln's supposed, yet often repeated quote, "I would like to have God on my side, but I must have Kentucky.” Modern historians select Lincoln's 1861 written quip “I think to lose Kentucky is nearly the same as to lose the whole game," with more confidence to capture the President's opinion of Kentucky's strategic value. ${ }^{269}$ Regardless which quote makes it into the analysis; the events in Kentucky throughout the entire war substantiate the sentiment. Kentucky provided resources, manpower, and an important geographic position that secured the Union's victory. Within the state population, splits occurred. The first split formed during the early debates on secession, and a minority of Kentuckians tossed their lot in with the Confederates. The second major split emerged in 1863 when Lincoln's emancipationist policies took effect. The federal efforts to curb guerilla violence that accompanied the emancipation phase of the war resulted in even more Kentuckians who shifted allegiance. A large majority of Southeastern Kentuckians, however, not only held steady to the Union cause, but also relied on increasing federal support as Confederate violence threatened the region. The rise of a Confederate identity during the postwar years in the central and western portions

${ }^{269}$ Richard Carwardine, Lincoln: A Life of Purpose and Power (New York: Knopf Publishing, 2003), 175-176. 
of the state signaled a strong disaffection with the war's impact in those areas. ${ }^{270}$

Residents of the southeastern counties created a different environment to remember the war—one that offered support for Republicans and Republican ideas.

In Kentucky, Conditional Unionists, proslavery Unionists, and other conservative groups formed a political partnership that kept the state out of the Confederacy in the earliest stages of the Civil War. By 1865, events in the second half of the war had dissolved much of that coalition. The results from the 1864 presidential election in Kentucky proved the waning influence and limited support of the federal administration. The Republican Lincoln and Unionist Democrat Andrew Johnson ran together under the split-ticket banner of a National Union Party. Kentucky returned the worst vote totals in the nation for Lincoln and Johnson's calculated effort at fusion politics. Over thirty Kentucky counties, mostly in the central and west, produced popular vote totals of $90 \%$ or more for the Democratic challenger George McClellan. The Eighth District, which included all the southeastern counties, provided a vote total of 6,409 votes for Lincoln and 3,701 for McClellan. Lincoln garnered only $30.2 \%$ of the vote statewide, but it was an improvement from 1860 and the president carried twenty-five Kentucky counties total with twelve of those in the Eight District. ${ }^{271}$

William Harrison Randall represented Kentucky's Eighth District in the United States House of Representatives during the latter half of the Civil War era. Randall had

\footnotetext{
${ }^{270}$ For the best analysis on how portions of Kentucky remade its Civil War legacy and identified with the Confederate cause see Anne Marshall's Creating a Confederate Kentucky: The Lost Cause and Civil War Memory in a Border State (Chapel Hill: University of North Carolina Press, 2010).

${ }^{271}$ James Larry Hood, "For the Union: Kentucky's Unconditional Unionist Congressmen and the Development of the Republican Party in Kentucky, 1863-1865," The Register of the Kentucky Historical Society, 76 (Summer 1978): 210.
} 
served as Circuit and County Clerk for Laurel County and after he won the congressional seat in the 1863 election, Randall allied with the Republican Party. Randall joined a group of Unconditional Unionists from Kentucky who defected from Union Democrats and, in one of his first actions, voted for an Army bill that allowed the arming of African Americans. ${ }^{272}$ In 1865 , when the House voted on the $13^{\text {th }}$ Amendment to abolish slavery in the United States, Kentucky representatives Lucian Anderson, George Yeaman, Green Smith, and William Randall cast votes in the affirmative. Representatives Anderson and Yeaman, from western districts, gambled their political futures and left the House in the next election. Smith scored a narrow victory in northern Kentucky and Eighth District voters reelected William Randall by a wide margin. ${ }^{273}$ Randall went on to lobby for more rights for African Americans after the war's conclusion. Historian Victor Howard added: "William H. Randall of Laurel County represented the eastern district of Kentucky in the House of Representatives and favored full civil rights for the Negro. In autumn of 1866 he traveled through his district while the county courts were in session and 'strongly advocated negro suffrage.',274

Union veterans experienced political support from the southeastern counties as well. In the 1867 gubernatorial race that featured Democrat John Helm, Republican Sidney Barnes, and Conservative William Kinkead, Helm won the race with $65.7 \%$ of the Kentucky vote. Barnes received $24.7 \%$ and Kinkead finished last with $9.6 \%$ in the three-

\footnotetext{
272 Ibid., 208.

${ }^{273}$ For more on the Kentucky Representatives who voted for the $13^{\text {th }}$ Amendment see Berry Craig's Unconditional Unionist: The Hazardous Life of Lucian Anderson, Kentucky Congressman (Jefferson: McFarland \& Company Publishers, 2016) and Berry Craig's "Four Profiles in Courage," Louisville Courier-Journal, Jan. 29, 2015. ${ }^{274}$ Victor Howard, Black Liberation in Kentucky: Emancipation and Freedom, 18621884 (Lexington: University Press of Kentucky, 1983), 72.
} 
way race. Jackson County led the voting for Barnes with 93.9\%, Whitley County offered the Republican $88.8 \%$, and Harlan County registered $84.9 \% .{ }^{275}$ Barnes raised the $8^{\text {th }}$ Kentucky Volunteers in southeastern Kentucky in 1861 and was present at Chattanooga when the group achieved national fame for raising the American flag on Lookout Mountain. For comparison, Barnes received 8.3\% in Jefferson County, 7.1\% in Warren County, and $0.9 \%$ in Fulton County. ${ }^{276}$ The shift toward the Democratic Party occurred in locations like Louisville, Lexington, Paducah, and Bowling Green.

In 1871, when Democrat Preston Leslie ran against Republican John Marshall Harlan, the state produced similar results. Leslie won with $58.6 \%$ of the state's popular vote. In Western Kentucky, Ballard and Fulton Counties produced vote totals of over 90\% for the Democratic candidate; for Northern Kentucky, Trimble and Owen Counties combined for over $90 \%$ support for Leslie as well. Five of the top eight counties for the Harlan's Republican candidacy included Jackson, Clay, Owsley, Whitley, and Harlan. ${ }^{277}$ When the Democratic candidate James B. McCreary defeated John Marshall Harlan in his second Republican bid to be governor in 1875, just six Kentucky counties favored Harlan with over $70 \%$ of the popular vote-all of those counties were in southeastern Kentucky. ${ }^{278}$ The former Colonel of the $10^{\text {th }}$ Kentucky Infantry and future Supreme Court Justice lost his two attempts to become Kentucky's governor, but Southeastern Kentuckians offered John Marshall Harlan his greatest political support of any region in Kentucky.

${ }^{275}$ Michael J. Durbin, United States Gubernatorial Elections, 1861-1911 (Jefferson: McFarland \& Company Publishers, 2010), 214-215.

${ }^{276}$ Ibid.

${ }^{277}$ Ibid., 216.

${ }^{278}$ Ibid., 216-217. 
Presidential races in the Commonwealth during the period of Reconstruction provided results that matched the gubernatorial contests. In 1868, when Union general Ulysses S. Grant ran as the Republican presidential candidate against Democrat Horatio Seymour, Kentucky voted just under $75 \%$ for Democrat Seymour and over twenty counties provided over $90 \%$ support for the Democratic candidate. Jackson and Harlan Counties were the only two counties that produced similar lopsided tallies in favor of Grant, and both counties eclipsed $90 \%$ in Republican support. ${ }^{279}$ Kentucky also provided Democrat Horace Greely a majority vote in Grant's reelection bid of 1872 . Kentucky was one of only six states to go to the Democratic challenger. Once again, Jackson, Owsley, Whitley, and the newly formed Bell County, voted at some of the highest rates for Grant observed in Kentucky, and the Republican carried most of the mountain district counties. ${ }^{280}$ The southeastern area continued with strong support for Republicans Rutherford B. Hayes and James Garfield in the 1876 and 1880 elections that followed the two-term administration of Ulysses S. Grant. The state of Kentucky, however, continued to award its electoral votes to the Democratic challengers. ${ }^{281}$

Modern historical efforts have downplayed the region's Unionism. In Kenneth Noe's "Toward the Myth of Unionist Appalachia, 1865-1883," Noe attacked the notion that Appalachians aligned with the Union as "ahistorical."282 Noe and Shannon Wilson coedited a work that made similar claims in The Civil War in Appalachia: Collected

${ }^{279}$ Presidential Elections, 1789-2008: County, State, and National Mapping of Election Data ed. Donald R. Deskin, Hanes Walton, and Sherman C. Puckett (Ann Arbor: The University of Michigan Press, 2010), 182-190.

280 Ibid.

${ }^{281}$ Ibid.

282 Kenneth Noe, “Toward the Myth of Unionist Appalachia, 1865-1883," Journal of the Appalachian Studies Association 6 (1994): 73-80. 
Essays. ${ }^{283}$ The Civil War in Appalachia suffered from the flawed approach of deconstructing a stereotype about an entire region and replacing it with an alternative revision of an entire region. In short, localities within the broad Appalachian portions of America experienced different levels of loyalty, participation, and outcomes in the Civil War era. Anne Marshall's Creating a Confederate Kentucky: The Lost Cause and Civil War Memory in a Border State offered a better analysis of Kentucky's complex history. Marshall's chapter “Two Kentuckys: Civil War Identity in Appalachian Kentucky, 18651915," distinguished the experiences of Kentucky, but the historian placed most of the analysis on exposing numerous outside efforts that embellished Appalachian Unionism. The chapter also placed significant focus on the rise of violent feuds in the area. Marshall concluded:

The perceived normality of the Confederate portion of Kentucky —an area capable of peaceful reunion - exacerbated Appalachian Kentucky's growing lawless reputation. Moreover, this perception that made Unionism seem an anomaly not only legitimized the state's Confederate identity but made it look like the preferable, more civilized one. ${ }^{284}$

Marshall's treatment of the area revealed significant difficulties in the region and her work acknowledged some of the unique characteristics of Kentucky's mountain populations. But "Two Kentuckys" also fell short in delineating how some localities developed a postwar culture distinct from the more violent counties. The southeastern portion of Kentucky experienced racial issues, suffered from lawless violence, and failed on social issues in the second half of the nineteenth century, as did much of the country. However, military service records, voting patterns, and other primary accounts suggest

${ }^{283}$ Kenneth Noe and Shannon Wilson eds., The Civil War in Appalachia: Collected Essays (Knoxville: University of Tennessee Press, 1997).

${ }^{284}$ Anne Marshall, Creating a Confederate Kentucky, 132. 
that many of the southeastern counties of Kentucky aligned with those who sought the preservation of the Union before, during, and after the war. And unlike much of Kentucky, a strong combination of Union loyalty and military pride survived the war and its aftermath.

In June 1861 W.J. Landram wrote Phillip Swagert where he said "Our men are for the Union— \& one thing is certain, Garrard [County] is going to stay in under all circumstances." ${ }^{285}$ Records show that Landram possessed one slave, but went on to serve in a Union Kentucky Regiment. ${ }^{286}$ Garrard County stood as one of the northernmost counties in the Eighth District, but his sentiment at the beginning of the war perhaps expressed an outlook of the area more than he knew. Charles C. Wells released a compilation of Union military records with his 1890 Special Veterans Census for Eastern Kentucky. ${ }^{287}$ The work listed the veteran records and rolls for thirty eastern counties, but many of the southeastern counties are not included. For Kentucky's one-hundred and twenty counties, only sixty-five of the records remain, as nearly half the state's veteran census data was either destroyed or misplaced in transfer to the National Archives. ${ }^{288}$ Historians face the difficult work in construction of the area's Civil War history to resurrect it from its forgotten state.

\footnotetext{
${ }^{285}$ W. J. Landram to Philip Swigert, 20 June 1861, Enrolled Militia Records 1864 1865 ; Adair, Allen, Boyle, Daviess, Garrard, Owen, Pendleton, and Shelby counties, Flat Box 7, Folder 861-865 GARRAD COUNTY RECRUITING \& RAISING CO. 7th Rgt Ky Militia, Kentucky Department of Military Affairs, Frankfort, KY. Accessed via the Civil War Governors of Kentucky Digital Documentary Edition, discovery.civilwargovernors.org/document/KYR-0002-079-0015. 286 "William Jennings Landram" in the Civil War Governors of Kentucky Digital Documentary Edition, discovery.civilwargovernors.org/document/N00009931. ${ }^{287}$ Charles C. Wells, 1890 Special Veterans Census for Eastern Kentucky (Baltimore: Gateway Press, 2000).

${ }^{288}$ Ibid., ix.
} 


\section{CHAPTER SIX \\ THE FIERY TRIAL: \\ A CIVIL WAR HISTIOGRAPHY}

Serious efforts to understand the Civil War emerged in the years following the war. Revisiting those earliest works, up through the voluminous amount of scholarship that exists today, reveals a rise in historical attention toward the subject. A higher quality of professional historical work accompanied the same trajectory. Biographies on Abraham Lincoln stand as an important strand of the larger Civil War histography as well. Lincoln officials and acquaintances such as John Nicolay, John Hay, and William Herndon produced some of the earliest efforts to capture the president's life in the years following the 1865 assassination. Other writers followed with late 1800's and early 1900s attention to Lincoln, prominent military leaders, and significant politicians. Inquiry into specific regional Civil War history, however, marks a more recent turn. As early researchers placed emphasis on the general history of the war and in producing biographical studies of its most important participants - with those works improving in quality as a hundred years passed - it has been only in the last twenty-five years that local histories connected to the Civil War have attracted historical scholarship. All these developments leave scholars with a better understanding of the war's leaders, causes, and consequences resulting in a rich library to advance new arguments as well as ask lingering questions worthy of deeper investigation. 
Questions surrounding the history of the Civil War encountered several problematic issues near its beginning such as geographic bias, writing tied to personal experience, and amateur historical efforts. These factors combined to present various interpretations of the war's significance in the earliest works. The "Lost Cause" approach produced many books that suffered from a pro-southern slant during the late nineteenth century and the first half of the twentieth century. Soldiers and politicians offered their memoirs on the conflict during Reconstruction and beyond. Subsequent historians, such as James Ford Rhodes and his History of the Civil War: 1861-1865, represented a more academic approach to the field. ${ }^{289}$ These turn-of-the-century works from veterans, politicians, and early historians present uneven results but mark the earliest foundations of the historiography of the Civil War.

By the mid-twentieth century writers such as Douglas Southall Freeman, Bruce Catton, and Allan Nevins published better researched works than the previous generation who addressed Civil War history. Freeman's multivolume study of Robert E. Lee in the 1930s entitled R. E. Lee: A Biography won praise for the depth of historical writing. ${ }^{290}$ Many still claimed to identify a strong southern bias, or at least an amount of Confederate romanticism, in Freeman's account. Later, Catton and Nevins introduced a generation of Americans to the topic of the Civil War with their narrative histories. Catton's 1952 trilogy of Mr. Lincoln's Army, Glory Road, and A Stillness at Appomattox introduced

289 James Ford Rhodes, History of the Civil War: 1861-1865 (New York: Reservoir House, 2016). Original publication in 1917. Rhodes won the second Pulitzer Prize ever awarded for history the same year.

${ }^{290}$ Douglas Southall Freeman, R.E. Lee: A Biography (New York: Scribner \& Sons, 1936). 
many readers to a deeper analysis of the Civil War. ${ }^{291}$ As a journalist who penned “popular history," Catton's work still stands as an important addition to the subject at a critical time in the historiography. The work also established what historians have challenged as an emphasis, or overemphasis, on the Eastern Theatre of the war. Allan Nevins published an eight-volume history over several decades of the mid-twentieth century with his The Ordeal of the Union. ${ }^{292}$ Like Catton, Nevins was not an academic historian, but he too fused prose and research in an academic way that presented Civil War history for a wider audience. Some historians have criticized the work as being too pro-Union, and as with Freeman, historians accused the expansive study of a detectable northern geographic bias.

Due to the growing interest of the last fifty years, scholars moved Civil War history forward from its popular and "Lost Cause" state. New scholars shifted from older "drum and trumpet" military history to "new" military history embedded in society and culture. The approach to the subject in the closing decades of the twentieth century challenged long-held assumptions. The topic received an additional boost, around the turn of the twenty-first century, due to a renewed attentiveness born from these works to meet the public's growing demand for new material on the topic. Anniversaries in the period between 2009-2015 that celebrated milestones of the war's significance made an impact as well. But instead of a decline in focus, research continues even with the passing of Lincoln's two-hundredth birthday and the conclusion of celebrations

${ }^{291}$ Bruce Catton, The Army of the Potomac, 3 volumes (New York: Doubleday Press, 1952).

${ }^{292}$ Allan Nevin, Ordeal of the Union, 8 volumes (New York: Scribner \& Sons, 1947-71). 
connected to the sesquicentennial of the war. Historians and publishers show no sign of abandoning the topic anytime soon.

Much of the attention awarded to the subject is due to the complex and domestic nature of the conflict, access to new sources, the biographical interest in its participants, and the uncovering of a vast expanse of topics unknown or previously ignored. More recent studies have shed new light on traditional subjects at the center of the conflict, while other historians have revealed original ideas and conclusions about matters long thought as peripheral. Within this surge of newly published material are also those books of scholarly recognition that stand the test of time and are viewed as essential reading to understand the war. These noteworthy scholars receive frequent reference for their thorough investigations that became indelible academic contributions to the field of Civil War history. Indeed, the sheer amount of material on the Civil War era, new and old, can present an overwhelming sensation for those who choose to measure or contribute to the ever-expanding field of study. It is useful to examine the modern study of the war starting with the works that appeared after the Civil Rights Movement and the Vietnam War Era.

I.

Historians have long analyzed the political history of the Antebellum Era and new conclusions on the topic emerged during the 1970s. During that decade, scholars added valuable works to the historiography that focused on the political environment surrounding the Civil War. Some of these efforts challenged prior positions and formed new views to advance a deeper understanding of the period. Among the most important 
of the new scholarship of the 1970s was Eric Foner's Free Soil, Free Labor, Free Men:

The Ideology of the Republican Party before the Civil War. Foner explored the formation of the Republican Party with an investigation into the development of a northern antebellum coalition organized around resistance to the further spread of slavery. ${ }^{293}$ The study examined the fusion politics of the period that coalesced members of various parties—including former Whigs, Know-Nothings, northern Democrats, Free-Soilers, and other northern political interests - into a political force that carried the 1860 presidential election. Additionally, Free Soil, Free Labor, Free Men analyzed the differences in regional perspectives, notably North and West, and emphasized the divide between politicians committed to the ideology of free labor, those who advocated colonization, and various aspects of radical abolitionism. Foner concluded that political cooperation between these groups increased and "during the 1850s, Republicans accepted the idea that the Negro should be given an 'equal chance' to prove himself capable of economic advancement, and their actions in state legislatures and in Congress had the effect of breaking down some of the legal inequalities which surrounded the black citizen." ${ }^{294}$ Completed during the turmoil of the Vietnam War and in a period of heightened awareness toward civil rights matters, Free Soil, Free Labor, Free Men offered insight to the political history connected to the Republican Party prior to the outbreak of the Civil War. The work also broke down the southern dominance of the histography and offered a thorough and fair examination of the Republican Party.

${ }^{293}$ Eric Foner, Free Soil, Free Labor, Free Men: The Ideology of the Republican Party before the Civil War (New York: Oxford University Press), 1970.

${ }^{294}$ Ibid., 299. 
Daniel Walker Howe's The Political Culture of the American Whigs provided another political study of the Antebellum Era at the close of the 1970s. In The Political Culture of the Whigs, Howe analyzed the philosophies that undergirded the antebellum Whig Party. ${ }^{295}$ With a biographical approach, Howe explored the regional and political diversity of the Whig Party examining politics through the lives of prominent Whig politicians - a list that included John Quincy Adams, Henry Clay, Alexander Stephens, and Abraham Lincoln. The distaste for President Andrew Jackson and subsequent Jacksonians created a political point of interest that held these diverse politicians together in a loose, yet common, cause. Foner and Howe's contributions improved political understanding and advanced the historiography of the Civil War era. With contemporary political issues, such as Vietnam, the Civil Rights Movement, and Watergate influencing the generation's view of history, these two authors allowed further exploration into the deeper political causes of the sectionalism that led to the American Civil War.

A modern comprehensive analysis of Abraham Lincoln's life emerged in the late 1970s with Stephen B. Oates's With Malice Toward None: A Biography of Abraham Lincoln. ${ }^{296}$ Oates offered an updated biography of Lincoln's life with a thorough examination of his rise from log cabin poverty through his actions as president. One of the real strengths of With Malice Toward None came in Oates's efforts to personalize Lincoln and his connection of the early biographical Lincoln to the political beliefs that the president later formed. Like Howe and Foner, Oates concluded that the opportunity

${ }^{295}$ Daniel Walker Howe, The Political Culture of the American Whigs (Chicago: University of Chicago Press, 1979).

${ }^{296}$ Stephen B. Oates, With Malice Toward None: A Biography of Abraham Lincoln (New York: Harper and Row, 1977). 
for economic and social mobility shaped Lincoln's core political philosophy against slavery. Oates added, “Thus, in Lincoln's view, slavery not only besmirched the ideals of the Declaration, but violated the principles of self-help, social mobility, and economic independence — all of which lay at the center of Republican ideology."297

Princeton historian James McPherson's Battle Cry of Freedom: The Civil War Era, published in 1988, did much to correct lingering misperceptions and mischaracterizations of Civil War history. ${ }^{298}$ Prior to McPherson's account, a few historians continued to view the war's causes with some uncertainty-with many works still holding to ideas that states' rights, tariffs, and other economic concerns formed the main catalysts of the war. Battle Cry of Freedom offered a large synthesis of the social, political, military, and economic factors of the war. McPherson placed his research in the broader context of antebellum issues where he argued that sectional strife, debates surrounding the institution of slavery, and efforts to halt slavery's expansion led to the outbreak of war in 1861. McPherson was not the first to link slavery and the Civil War directly, but the large volume won the Pulitzer Prize in history and represented a watershed moment in the historiography of the Civil War. Since his work, most scholars accept slavery as the root cause of the Civil War and what remnants of Lost Cause explanations that existed declined. The astute work found in Battle Cry of Freedom, combined with the widespread popularity of PBS's 1990 release of Ken Burn's

\footnotetext{
${ }^{297}$ Ibid., 166-67.

298 James McPherson, Battle Cry of Freedom: The Civil War Era (New York: Oxford University Press, 1988).
} 
miniseries The Civil War, created an environment where scholars and the general population were eager for more on the topic of the Civil War. ${ }^{299}$

\section{Gerald Linderman's Embattled Courage: The Experience of Combat in the}

American Civil War was another late 1980s addition that advanced understanding the war with focus on soldiers' personal perspectives. ${ }^{300}$ Linderman examined the lives of ordinary soldiers who fought in the war to assess the motivations for enlistment, the characteristics of the men at war, and the outlook soldiers expressed through letters while surrounded by danger and death. Embattled Courage revealed the experiences of men who marched and fought on the frontlines and the narrative helped readers to understand the source of courage that accompanied them during the war. Works such as Battle Cry of Freedom, The Civil War, and Embattled Courage piqued the interests of historians in the late 1980s, led the way for more works, and helped to reestablish the war as a central topic of study.

Perhaps more so than any other topic, the Lincoln presidency benefitted from the surge in interest and renewed focus. Mark Neeley Jr. cleared some of the charges attached to Lincoln's prosecution of the war as Commander in Chief in his 1992 Pulitzer Prize winning account The Fate of Liberty: Abraham Lincoln and Civil Liberties. ${ }^{301}$ Neely's research relied upon a thorough historical examination of Civil War arrest records to identify any potential motivations of partisanship behind the president's controversial executive war measures - a popular charge made by Lincoln critics. The

\footnotetext{
${ }^{299}$ Ken Burns, et al., The Civil War (Burbank, CA: PBS Home Video, 2004).

${ }^{300}$ Gerald F. Linderman, Embattled Courage: The Experience of Combat in the American Civil War (New York: The Free Press, 1987).

${ }^{301}$ Mark Neeley Jr., The Fate of Liberty: Abraham Lincoln and Civil Liberties (New York: Oxford University Press, 1991).
} 
Fate of Liberty concluded that Lincoln had not acted with political revenge in mind with his suspension of habeas corpus or his declarations of martial law; instead the evidence suggested that he used the executive maneuvers sparingly and only as a necessity to protect Union interests during the war. This revised perspective on Lincoln's perceived blemish regarding his record toward civil liberties represented a perspective shift in the historiography of the topic. Neely followed up his rich award-winning account with another look at the presidency in The Last Best Hope of Earth: Abraham Lincoln and the Promise of America. ${ }^{302}$ This addition kept the narrowed approach as Neely focused on the actions, strategy, and decisions that Lincoln made as president. Neely attributed this change in direction to James McPherson. McPherson led historical efforts to depart from the pure biographical and introspective psychohistory that dominated Lincoln research in the years prior to the 1990s with the hope of turning more historians toward examinations of "the war president." 303 The Last Best Hope of Earth detailed Lincoln's leadership and tendencies in carrying out the war. The work also increased focus on Lincoln's habits as a war president, his ability to politically manage the war, and the military acumen that he developed.

David Herbert Donald's 1995 work Lincoln, released the following year, reverted to the previous mode of approach with a study large in both breadth and scope. ${ }^{304}$ In Lincoln, Donald highlighted a perceived passivity in Lincoln's nature. Among the chief characteristics illuminated as central to Lincoln the politician was a religious fatalism

${ }^{302}$ Mark Neeley Jr., The Last Best Hope of Earth: Abraham Lincoln and the Promise of America (Cambridge: Harvard University Press, 1993).

${ }^{303}$ Ibid., v-vi.

${ }^{304}$ David Herbert Donald, Lincoln (New York: Simon and Schuster, 1995). 
based on the doctrine of necessity combined with a presidency directed by practical means. Completed during the Bill Clinton presidency, the study showed signs of contemporary influence in its findings. Additionally, the large biographical work placed a high value on the influence of Lincoln's surroundings from his young days in a log cabin through his presidential years. This approach began drawing a criticism from some in the field. The reticent nature of Lincoln has always made him a difficult but attractive case study to historians; however, new approaches soon replaced the obtuse nature of the biographical approach.

Prior to Donald's Lincoln, works such as Michael Burlingame's The Inner World of Abraham Lincoln, sought to psychoanalyze the sixteenth president. ${ }^{305}$ Another example, Gabor Boritt's edited collection The Historian's Lincoln: Pseudohistory, Psychohistory, and History, presented a group of essays that sought deeper sources of inspiration to analyze Lincoln's motives and actions. ${ }^{306}$ One of the more insightful pieces included in the edition was Boritt's own "Lincoln and the Economics of the American Dream.” ${ }^{307}$ Boritt traced Lincoln's economic philosophy more to his Whiggish leanings and the emergence of a Republican spirit than to the Jeffersonian philosophy of the independent farmer. The essay also described the central idea of Lincoln's vision for America as a transformational extension of Jacksonian democratic principles of common advancement combined with an anti-slavery attitude. This combination acted to redefine

\footnotetext{
${ }^{305}$ Michael Burlingame, The Inner World of Abraham Lincoln (Urbana: University of Illinois Press, 1997).

${ }^{306}$ The Historian's Lincoln: Pseudohistory, Psychohistory, and History ed. Gabor S. Boritt (Urbana: University of Illinois Press, 1988).

${ }^{307}$ Gabor S. Boritt "Lincoln and the Economics of the American Dream." In The Historian's Lincoln, 87-106.
} 
equality for Americans as an "equal opportunity to get ahead in life." 308 The eclectic collection of essays marked an effort that represented the broader trends in Lincoln's historiography that occurred in the last decades of the twentieth-century. Some historians held to the abstract approach, while others were eager to analyze the better documented realities of Lincoln's economic, political, and social reasoning - some tried both.

Another addition into the field on the sixteenth president was Allen Guelzo's Abraham Lincoln: Redeemer President. ${ }^{309}$ Guelzo fused Lincoln's economic outlook, his moral principles, and his political reasoning with an effort that produced a deeper understanding of the president. Using an exploration of Whig political philosophy leading up to the formation of the Republican Party, along with new arguments centered on Lincoln's faith and moral foundations, Guelzo advanced a more complex analysis about what directed the president's actions. Guelzo also connected Lincoln's understanding of the American founding and concluded that "the Founding Fathers had never intended that slavery continuously extend itself over the continent and, contrary to John Calhoun, that the Fathers had always assumed that the federal government had full jurisdiction over the organization of the territories and the migration of slavery into them." 310

After passing into the twenty-first century and anticipating the bicentennial of Lincoln's birth, historical works on Abraham Lincoln increased in number and quality.

\footnotetext{
308 Ibid., 93-94.

${ }^{309}$ Allen C. Guelzo, Abraham Lincoln: Redeemer President (Grand Rapids: Eerdmans Publishing, 1999).

${ }^{310}$ Ibid., 237.
} 
In 2002, William Miller published Lincoln's Virtues: An Ethical Biography. ${ }^{311}$ Miller's contribution examined Lincoln through the prism of morality and politics. In a narrowed, yet biographical approach, Miller traced the shaping of Lincoln's moral character and intellectual development through the experiences of his life and gave close attention to events that either shaped or revealed his ethical disposition. Miller's conclusions claimed that Lincoln experienced an escalation of moral character the further he rose in politics. Furthermore, Lincoln fulfilled the role as president and dealt with slavery with a unique human agency — much of it drawn from the moral principles that evolved from a lifetime of exposure to difficulty. Writing from the University of Virginia as a scholar at the Miller Center of Public Affairs, Miller's and other historians' increased attention to presidents, particularly Abraham Lincoln, represented a trend of scholarly movement that improved understanding of the executive office.

Richard Carwardine's Lincoln is one of the most valuable additions to the library on Lincoln in the modern era. ${ }^{312}$ As Oxford University Rhodes Professor of American History, Carwardine offered a transatlantic viewpoint on Lincoln's contributions to antebellum America and the Civil War era. The central purpose of Lincoln-later republished as Lincoln: A Life of Purpose and Power - was to describe the sources of Lincoln's power. Carwardine argued that Lincoln's power came from his personal ambition, his ability to react to public opinion, and through his political skill to navigate party politics. Economic philosophy was a source of interest throughout Carwardine's

${ }^{311}$ William Lee Miller, Lincoln's Virtues: An Ethical Biography (New York: Alfred A. Knopf, 2002).

312 Richard J. Carwardine, Lincoln (Edinburgh: Pearson Education Limited, 2003). Carwardine's book would later be republished for American audiences as Lincoln: A Life of Purpose and Power (New York: Vintage Books, 2007). 
work as well, and the historian suggested that Lincoln "empathized with those who were, as he had been, struggling self-improvers." ${ }^{\prime 313}$ Holding firm to his Whig roots, Lincoln sought to establish a form of meritocracy and Carwardine believed that the "wartime program of railroad construction, high tariffs on imported manufactures, homestead and land-grant laws, scientific agriculture, progressive taxation, and a national banking structure, did indeed draw a line under the republic of Jefferson and Jackson, and announced the arrival of a national government pledged to a liberated commercial order. ${ }^{314}$ Lincoln used a chronological approach to observe the evolution of the president's skills and beliefs.

Carwardine also addressed a topic of interest with Lincoln historians- - his faith. In an earlier work, Evangelicals and Politics in Antebellum America, Carwardine researched the impact of religion and churches on various regional beliefs related to slavery. ${ }^{315}$ In the study, Cawardine gave specific attention to the denominations of the Methodists and the Baptists to identify any potential influences on the crystallizations of slave opinion. As an authority on matters of religion and antebellum America, Carwardine also explored the faith of the president in Lincoln. The historian viewed Protestant millennialism and Enlightenment rationalism to work in tandem to guide the president. Over the course of previous efforts to identify Lincoln's faith, historians have been quick to point to Lincoln's deistic tendencies, some have carelessly labeled him an atheist, while others have found or invented evidence they used to place the president

\footnotetext{
313 Ibid., 48

${ }^{314}$ Ibid., 256-257.

315 Richard J. Carwardine, Evangelicals and Politics in Antebellum America (New Haven: Yale University Press, 1993).
} 
under a specific religious denomination. Carwardine used a well-researched and balanced approach to determine that a broad influence was indeed important to Lincoln's development and expression of religious beliefs. Carwardine's research and synthesis aided the understanding of the faith of the president thus shaping the historiography with a lasting perspective on this key aspect of Lincoln's leadership and life.

In 2005, acclaimed historian Doris Kearns Goodwin, a previous winner of the Pulitzer Prize, published A Team of Rivals: The Political Genius of Abraham Lincoln. ${ }^{316}$ Goodwin's much anticipated book received enormous attention from general readers and scholars alike. The analysis focused on the political calculations of Lincoln with special attention on the relationships that he forged with, and between, William Seward, Salmon Chase, Edward Bates, Edwin Stanton—men that filled part of his cabinet. The large study explored the skills of Lincoln's ability to manage political personalities while he built a coalition of support for his own political and war aims. The work marked a huge point in the historiography of Lincoln as Team of Rivals appealed to a larger audience as popular history; yet, the work put forth research valuable to scholars. Another key element was the emerging focus on specific and narrowed historical aspects surrounding Abraham Lincoln. Rather than the catch-all biography, Goodwin's work presented a path for more nuanced work on the former president.

With the continued growth of interest in Abraham Lincoln, historians began to offer even more focused works that examined specific events and timeframes within the president's life. Harold Holzer's 2004 release of Lincoln at Cooper Union: The Speech

${ }^{316}$ Doris Kearns Goodwin, A Team of Rivals: The Political Genius of Abraham Lincoln (New York: Simon and Schuster, 2005). 
That Made Abraham Lincoln President presented an effort that analyzed Lincoln's famous New York address. ${ }^{317}$ Holzer framed the speech as a pivotal moment that captured national sentiments and concluded that the event gave rise to the political success that followed. Furthermore, Lincoln at Cooper Union measured the reception of the February 1860 address and synthesized how that the speech symbolized and coalesced the political outlook of the North. Louis Mansur's Lincoln's Hundred Days: The Emancipation Proclamation and the War for the Union isolated the specific time frame of Lincoln's September 1862 announcement of the Emancipation Proclamation and the period in January 1863 when the measure took effect. ${ }^{318}$ Lincoln's Hundred Days revealed an in-depth study of a critical policy and timeframe within the larger Lincoln administration. These works reflected a movement within the historiography of Lincoln that attempted to isolate political aspects of the administration without revisiting the broader biography of the president.

Other works took a similar limited approach and examined timeframes prior to the election and just before the inauguration of the president. Douglas Egerton's Year of Meteors: Stephen Douglas, Abraham Lincoln, and the Election that Brought on the Civil War addressed the critical year of 1860 in effort to advance the historical importance of numerous events leading up to the election of Lincoln. ${ }^{319}$ Egerton's work focused on the political rivalry between Abraham Lincoln and Stephen Douglas and shed new light on

${ }^{317}$ Harold Holzer, Lincoln at Cooper Union: The Speech that Made Abraham Lincoln President (New York: Simon and Schuster, 2004).

${ }^{318}$ Louis P. Mansur, Lincoln's Hundred Days: The Emancipation Proclamation and the War for the Union (Cambridge: Belknap Press, 2012).

${ }^{319}$ Douglas R. Egerton, Year of Meteors: Stephen Douglas, Abraham Lincoln, and the Election that Brought on the Civil War (New York: Bloomsbury Press, 2012). 
the fracturing of the pre-war Democratic Party. Published within a few years of Year of Meteors, Harold Holzer offered a similar work with his Lincoln President-Elect: Abraham Lincoln and the Great Secession Winter 1860-1861. ${ }^{320}$ As a follow-up to Lincoln at Cooper Union, Holzer continued the trend of examining specific periods concerning the significance of Abraham Lincoln in a way that allowed historians to fully explore the events and environment surrounding the Civil War.

With the passing of bicentennial celebrations in 2009 to mark the two-hundredth birthday of Lincoln, works confronted scholars with new arguments. Mark Neeley presented another focused approach with Lincoln and the Triumph of the Nation: Constitutional Conflict in the American Civil War. ${ }^{321}$ Neeley examined the legal history of the Civil War with specific interest on constitutional issues, Lincoln's legal view of the prosecution of the war, and the elimination of slavery. Neeley asserted that the president interpreted the Constitution the best he knew how and concluded that the sixteenth president did not developed a radical new nationalism at the core of his desire for change. In addition, Lincoln and the Triumph of the Nation revealed an original topic of study through weaving in the Confederate Constitution and reminding historians "it is important to recall constitutional history—especially that neglected constitutional history of the states." ${ }^{322}$ Conscription, emancipation, and punishment are a few of the topics that Lincoln and the Triumph of the Nation addressed with interest in Lincoln's constitutional reasoning.

\footnotetext{
${ }^{320}$ Harold Holzer, Lincoln President-Elect: Abraham Lincoln and the Great Secession Winter 1860-1861 (New York: Simon and Schuster, 2008).

${ }^{321}$ Mark E. Neely Jr., Lincoln and the Triumph of the Nation: Constitutional Conflict in the American Civil War (Chapel Hill: The University of North Carolina Press, 2010). ${ }^{322}$ Ibid., 155.
} 
Eric Foner published The Fiery Trial: Abraham Lincoln and American Slavery

the same year. ${ }^{323}$ In the historiography of Lincoln, some historians challenged Lincoln's views on slavery and race-making special effort to deconstruct the "Great Emancipator" image. The DeWitt Clinton Professor of History at Colombia University pushed back in his account. A central purpose of The Fiery Trial was the belief that Lincoln's fierce antislavery stance had more in common with the abolitionists than some studies suggested. To measure Lincoln's impulses toward slavery, Foner linked the president's free-labor outlook to his antislavery views and argued that the ideas conjoined to concentrate on matters of social and political economy. ${ }^{324}$ The relevance of this sentiment underscored the fact that Lincoln wanted a social advancement for the country, reconciled some matters of race to pursue a legal economic equality in opportunity, and did not hold, nor project, some of the more extreme views toward free blacks of the time. Moreover, Foner made a case for Lincoln's careful handling of the slavery issue with practical and political realities in mind. The strong contextualization of Lincoln's views, words, and policies through his evolution on the issue of slavery was the strength of Foner's work. The Fiery Trial won the 2011 Pulitzer Prize for History.

Founders' Son: A Life of Abraham Lincoln is one of the latest additions to the crowded field to address the Civil War President. ${ }^{325}$ As the senior editor of the National Review, Richard Brookhiser traced Lincoln's political courage to his high admiration of the Founding Fathers. Brookhiser connected Lincoln to George Washington, Thomas

${ }^{323}$ Eric Foner, The Fiery Trial: Abraham Lincoln and American Slavery (New York: W.W. Norton and Company, 2010).

${ }^{324}$ Ibid., 116-117.

${ }^{325}$ Richard Brookhiser, Founders' Son: A Life of Abraham Lincoln (New York: Basic Books, 2014). 
Jefferson, Thomas Paine, and other figures of early American history to derive the origins of Lincoln's deeper philosophies. Brookhiser analyzed numerous primary sources from Lincoln's speeches and letters to establish a connection to Lincoln's affinity to founding documents such as the Declaration of Independence, the Northwest Ordinance, and the Constitution. Brookhiser argued that Lincoln's view of the Union, with the eventual abolition of slavery, reflected an interpretive effort to be congruent with the Founding Fathers' long view. In historiographical relevance, Founders' Son is a strong example of an opposition to the Lost Cause portrayal of Lincoln as a radical destroyer of liberty, as well as the more exaggerated claims of his presidency being a drastic progressive departure from the founding generation. With Lincoln's newfound popularity and undeniable historical significance, all sides of the political spectrum stretched efforts and conclusions to claim him.

A recent effort that made bold claims on Lincoln's view on national economic policy emerged in the 2015 work A Just and Generous Nation: Abraham Lincoln and the Fight for American Opportunity ${ }^{326}$ Historian Harold Holzer and economist Nicholas Garfinkle work together to uncover Lincoln's economic outlook and conclude that the president's desire to create an environment where individuals could self-improve had a far greater influence on actions than previous historians have addressed. Critics charged A Just and Generous Nation with modern political bias as the authors used Lincoln's economic reasoning to attack contemporary policy. Nonetheless, scholars praise the first

${ }^{326}$ Harold Holzer and Nicholas Garfinkle, A Just and Generous Nation: Abraham Lincoln and the Fight for American Opportunity (New York: Basic Books, 2015). 
half of the book for its depth and clarity in examining a specific outlook that influenced Lincoln's actions.

While the actions of the newly elected Republican administration of the $1860 \mathrm{~s}$ serve as one aspect of a larger body of work on the Civil War, some of America's most talented scholars shaped the new historiography of Lincoln with dedicated research. In a large field where hagiography and biased attacks on leaders of Lincoln's stature both exist, these works offer a balanced look at the president and are grounded in good research and historical methods of study.

II.

As perspectives changed with political and national examinations of the war, new views related to regional and state history emerged as well. With Kentucky, most historians identify E. Merton Coulter's 1926 account, The Civil War and Readjustment in Kentucky, as the early cornerstone of history focused on Civil War Kentucky. ${ }^{327}$ Coulter argued that Kentucky's economic ties with the North, its beliefs that slavery would be better protected in the Union, and a long tradition of compromise kept Kentucky, a slave state, from abandoning the Union in favor of the Confederacy. Coulter also viewed Kentucky's policy of neutrality and events that pulled the state into the Union as a precursor for the trouble that followed the war. In short, Coulter argued that Kentucky's Confederate sympathies rose from the sense of betrayal that manifested in the state and its residents with emancipation as well as heavy handed Reconstruction policies. This dated work, now approaching one hundred years old, has drawn both praise for its lasting

${ }^{327}$ E. Merton Coulter, The Civil War and Readjustment in Kentucky (1926). 
influence, but also faces modern criticism in the detection of southern bias in its conclusions and the number of new sources made available since its completion.

Fifty years later, Lowell Harrison produced a short influential work with focus on Kentucky's experience with the Civil War with his The Civil War in Kentucky. ${ }^{328}$ This study offered a concise account of military and political events that occurred during the war in Kentucky. Though not intended as a comprehensive account of the war in Kentucky, Harrison's work provided a valuable summary of military battles in the state. Long viewed as an essential companion to Coulter's work, The Civil War in Kentucky documented the outbreak of war, the Confederate invasions of 1862, and Kentucky's reaction to military and executive measures used through the declaration of martial law. Harrison used military records, political correspondence, and newspaper sources to highlight the actions of notable politicians and military leaders. Harrison echoed Coulter, "It has been said with considerable truth that Kentucky joined the Confederacy after the war was over." ${ }^{\prime 29}$ Many scholars have repeated this assertion, but the expression overlooked the diversity of regional sentiments in the state. Harrison and James C. Klotter coauthored a comprehensive look at the state in A New History of Kentucky. ${ }^{330}$ The book offered a short update to the Civil War in Kentucky with chapters named "The Road to War" and "The Civil War." 331 Released in the mid-1990s, A New History of Kentucky sounded a more balanced tone than earlier works reminding readers that "the

\footnotetext{
${ }^{328}$ Lowell H. Harrison, The Civil War in Kentucky (Lexington: University Press of Kentucky, 1975).

${ }^{329}$ Ibid., 106.

${ }^{330}$ Lowell H. Harrison and James C. Klotter, A New History of Kentucky (Lexington: The University Press of Kentucky, 1997).

${ }^{331}$ Ibid., 181-212.
} 
ties with the Union were also strong. An appreciable number of Kentuckians had connections with Pennsylvania and other northern states, and Kentuckians were proud of the reputation they had established in fighting for the nation in several wars." 332

Amid an increased turn-of-the-century focus on Abraham Lincoln at the national level, Harrison also published Lincoln of Kentucky in 2000. ${ }^{333}$ Lincoln of Kentucky explored the relationship between Lincoln and his three law partners, his three romantic interests, his political idol (Henry Clay), and his best friend (Joshua Speed) who were all Kentuckians. This approach helped to establish the relevance of the state on Lincoln's life. The real strength of Harrison's book, however, was his analytical approach to Lincoln's relationship with Kentucky during the Civil War. The immediate concerns for Lincoln at the outbreak of war centered around how to hold the slave state in the union. Harrison traced Lincoln's handling of Kentucky through numerous state-specific correspondences between military leaders such as General Ulysses S. Grant and General Jeremiah Boyle, Kentucky governors such as Governor Beriah Magoffin and Thomas Bramlette, and information obtained from trusted local individuals - trust he developed from previous friendships. Lincoln of Kentucky asserted that "with all the other burdens that he bore as the wartime leader of the nation, Lincoln had to devote considerable attention to affairs in his native state. He understood prickly Kentuckians better than most of the military commanders who were assigned there." ${ }^{334}$ As admiration for Lincoln rose nationally, Kentucky, too, celebrated the memory of the sixteenth president.

\footnotetext{
332 Ibid., 181.

${ }^{333}$ Lowell H. Harrison, Lincoln of Kentucky (Lexington: The University Press of Kentucky, 2000).

${ }^{334}$ Ibid., 213.
} 
Harrison's work was an important addition to the historiography of Kentucky in the Civil War and marked a departure from some of the Confederate sympathies expressed in works throughout the previous century.

Border State history attributed to the growing historiography of the Civil War and received increased attention amid the rise of other national efforts in the 2010s. William C. Harris' Lincoln and the Border States: Preserving the Union examined Lincoln's efforts to maintain Maryland, Missouri, Kentucky, and Delaware in the Union. ${ }^{335}$ Building on Coulter's and Harrison's arguments, Harris used Lincoln's letters to political and military leaders to extend the understanding of Lincoln's careful approach that kept Kentucky in the Union. Lincoln and the Border States assessed Lincoln's preoccupation with problems in the Upper South, his handling of controversies in certain regions, and the patient management he developed with troubles in the area. Furthermore, Harris argued that the states were not safely in the Union as early as some historians have suggested, and that Lincoln's masterful approach to these areas proved critical for emancipation efforts and winning the war. Aaron Astor's Rebels on the Border: Civil War, Emancipation, and the Reconstruction of Kentucky and Missouri followed a year later. ${ }^{336}$ Astor analyzed similarities between Kentucky and Missouri with focus on the Border States that remained in the Union. Astor's study examined how guerrilla war, race, and shifting allegiances combined with broader trends to create a unique and violent

${ }^{335}$ William C. Harris, Lincoln and the Border States (Lawrence: University Press of Kansas, 2011).

${ }^{336}$ Aaron Astor, Rebels on the Border: Civil War, Emancipation, and the Reconstruction of Kentucky and Missouri (Baton Rouge: Louisiana State University Press, 2012). Astor also built upon Daniel Croft's arguments from Reluctant Confederates: Upper South Unionists in the Secession Crisis. (Chapel Hill: University of North Carolina Press, 1989). 
Civil War experience for these localities. Christopher Phillips' The Civil War in the Border South: Reflections in the Civil War Era offered a different view on the Border States the following year. ${ }^{337}$ Phillips' work acknowledged the importance of military affairs on holding the Border States in the Union and he analyzed the chronological unfolding of the war with specific attention to the military campaigns conducted. One chapter connected the Confederate offensive mounted in Kentucky to General Robert E Lee's Antietam campaign. The direction of historiography seemed to use the events in these pivotal states to explain the larger implications on the national execution of the war. Prior efforts often separated the war into the Eastern and Western Theatres.

Patrick Lewis' For Slavery and Union: Benjamin Buckner and Kentucky Loyalties in the Civil War represented a continuation in attention to local Civil War history. ${ }^{338}$ Lewis's account, examined Benjamin Forsythe Buckner as a model proslavery unionist. For Slavery and Union analyzed the deterioration of Buckner's loyalty to the Union that resulted from Lincoln's federal policies and the eventual emancipation of slaves. The study provided interesting insight on the decline of wealthy Central Kentucky families' loyalty with regards to support of the Union. Lewis used local history and accounts to determine that emancipationist policies created a wide disaffection in slaveholding families within Central Kentucky. The Buckners began the war with a form of conservative unionism that stood against secession but transformed to represent trends of defiance with Kentucky's wider disillusionment toward Republican and military policies.

${ }^{337}$ Christopher Phillips, The Civil War and the Border South: Reflections on the Civil War Era (Santa Barbara: Praeger Publishing, 2013).

${ }^{338}$ Patrick A. Lewis For Slavery and Union: Benjamin Buckner and Kentucky Loyalties in the Civil War (Lexington: University Press of Kentucky, 2015). 
War memory has a short yet valuable historiography as well. Barbara Gannon's The Won Cause: Black and White Comradeship in the Grand Army of the Republic explored the integration of GAR posts. ${ }^{339}$ Gannon noted, "Black veterans were the political and social equals of white Americans in one of the most prestigious organizations in the United States. In an era in which race trumped virtually all other social identities, black and white veterans created an interracial organization at both the national and state levels." 340 The Won Cause demonstrated the way that Civil War memory and the celebration of experiences from the war created unique opportunities for historians to examine social and political change.

\section{Anne Marshall's Creating a Confederate Kentucky: The Lost Cause and Civil}

War Memory in a Border State is another title that contributed to the historiography of the Civil War. ${ }^{341}$ In her study, Marshall established a pre-war Unionist majority in Kentucky and revealed a variety of motives that drove that loyalty. Like other historians who have examined Kentucky's diverse and unique Unionism, Marshall found that the federal protection of slavery, anti-slavery attitudes from Appalachian residents, small pockets of abolitionism, economic opportunists, and calculating politicians all represented a conglomerate of Union interests in the state. Marshall's analysis of the complex prewar attitudes and her investigation of reactions to interwar events provide an important pretext to the synthesis located throughout the rest of the book. Political realignment, racism, and other Lost Cause activities are points of emphasis for Marshall's

${ }^{339}$ Barbara A. Gannon, The Won Cause: Black and White Comradeship in the Grand Army of the Republic (Chapel Hill: University of North Carolina Press, 2011). 340 Ibid., 7.

${ }^{341}$ Anne E. Marshall, Creating a Confederate Kentucky: The Lost Cause and Civil War Memory in a Border State (Chapel Hill: University of North Carolina Press, 2010). 
exploration of post-war Kentucky. As most Kentuckians began to identify themselves both with, and as, Southern Democrats during Reconstruction, Marshall connected the strong Republican disaffection to attitudes generated from the military and federal government's emancipation of slaves and controversial war measures. Creating a Confederate Kentucky identified the way memory can change to fit a new political opinion with a location.

Sister States, Enemy States: The Civil War in Kentucky and Tennessee edited by Kent T. Dollar and Larry H. Whiteaker offered several essays that investigated the motivations and historical causes of loyalty within Kentucky and Tennessee. ${ }^{342}$ A few works from this collection include Thomas Mackey's 'Not a Pariah, but a Keystone: Kentucky and Secession" that examined the deeper relationship between Kentucky and the state's decision to remain in the Union. Kenneth Noe's "Battle Against the Traitors: Unionist Middle Tennesseans in the Ninth Kentucky Infantry" provided insight to soldiers who left the Confederacy to fight for the Union. John D. Fowler's "We Can Never Live in a Southern Confederacy: The Civil War in East Tennessee" also looked at the regional differences between the Appalachian portion of the state versus the more pro-Confederate middle and west. This compilation of essays from modern scholars committed to the study marked an effort to understand the complexities of these two important border states often ignored by more general Civil War works.

Christopher Phillips's The Rivers Ran Backward: The Civil War and the Remaking of the American Middle Border represents one of the most expansive studies

${ }^{342}$ Kent T. Dollar and Larry H. Whiteaker, ed., Sister States, Enemy States: The Civil War in Kentucky and Tennessee, (Lexington: University Press of Kentucky, 2009). 
on the border region to date. ${ }^{343}$ Phillips's work investigates the contested loyalties of the border region with attention to the factors that influenced diverse populations in those areas. The Rivers Ran Backward sheds light on the complex political and economic bonds, North and South, to the respective sides that citizens chose to align with across several states where political opinion varied. The work stands as the first serious modern effort that attempts to look beyond simple state lines in the hopes of identifying causes for either support or resistance to the Union or Confederate cause.

IV.

The secondary literature on Civil War history has experienced a dramatic evolution and improvement in the last fifty years. As the subject continues to receive the increased attention of scholars, the national complexities of America's greatest domestic crisis become clearer and more understandable. It is estimated that a new book related to the Civil War hits the market each day. The history surrounding Abraham Lincoln has grown exponentially. Work from scholars like Eric Foner, Mark Neely, James McPherson, Richard Cawardine, and others have allowed readers to better understand the significance of his presidency. Local and state history is a beneficiary of the trend as well. With the rise of genealogical studies, digital record keeping, and technological means of sharing information, both the interest and the ability to pursue historical questions have improved.

${ }^{343}$ Christopher Phillips, The Rivers Ran Backward: The Civil War and the Remaking of the American Middle Border (Oxford: Oxford University Press, 2016). 
Some areas are still catching up and the historiography of the Civil War is far from complete. Appalachian areas are just starting to receive the contemporary attention that other topics have long received. Instead of simplifying explanations with blanket geographical conclusions, historians are now beginning to narrow down to towns and areas in the search for relevant, unique, and interesting historical studies. An example of a gap in the literature is the southeastern portion of Kentucky. Union participation in the war was high, slave ownership was low, and more interesting - the area bucked state trends and offered sustained support for the Republican party well after the war.

One can look for the trend of the growth in Civil War studies to continue, it will be both valuable and interesting to see what this renaissance in Civil War history produces in the decades to come. To match the work of scholars over the last half century would be a challenge, but one that a new generation of historians is ready to accept. 


\section{REFERENCES}

\section{SECONDARY LITERATURE}

Ash, Stephen V. When the Yankees Came: Conflict and Chaos in the Occupied South, 1861 -

1865. Chapel Hill: The University of North Carolina Press, 1995.

Astor, Aaron. Rebels on the Border: Civil War, Emancipation, and the Reconstruction of Kentucky and Missouri. Baton Rouge: Louisiana State University Press, 2012.

Billings, Dwight B. and Blee, Kathleen M. The Road to Poverty: The Making of Wealth and

Hardship in Appalachia. Cambridge: Cambridge University Press, 2000.

Boritt Gabor S. ed. The Historian's Lincoln: Pseudohistory, Psychohistory, and History. Urbana:

University of Illinois Press, 1988.

Brookhiser, Richard. Founders' Son: A Life of Abraham Lincoln. New York: Basic Books, 2014.

Bunting III, Josiah. Ulysses S. Grant. New York: Henry Holt \& Company Times Books, 2004.

Burlingame, Michael. The Inner World of Abraham Lincoln. Urbana: University of Illinois Press,

1997.

Burns, Ken et al., The Civil War. Burbank, CA: PBS Home Video, 2004.

Carwardine, Richard J. Evangelicals and Politics in Antebellum America. New Haven:

Yale

University Press, 1993.

. Lincoln. Edinburgh: Pearson Education Limited, 2003.

. Lincoln: A Life of Purpose and Power. New York: Knopf Publications, 2006. 
Press, 2017.

Lincoln's Sense of Humor. Carbondale: Southern Illinois University

Carwardine, Richard and Sexton, Jay., ed. The Global Lincoln. New York: Oxford University Press, 2011.

Catton, Bruce. The Army of the Potomac, 3 volumes. New York: Doubleday Press, 1952.

Clark, James L. "Clay County's Andrew Clark and the Civil War in Kentucky,” Clay County

Ancestral News, Manchester: Clay County Genealogical and Historical Society, 2003.

Clark, Thomas D. A History of Laurel County: An Account of the Emergence of a Frontier

Kentucky Appalachian Community. London: Laurel County Historical Society, 1989.

Coulter, E. Merton. The Civil War and Readjustment in Kentucky. Chapel Hill:

University of

North Carolina Press, 1926. reprint Gloucester, Mass.: Peter Smith, 1966.

Cozzens, Peter. The Shipwreck of Their Hopes: The Battles for Chattanooga. Urbana:

University of Illinois Press, 1994.

Craig, Berry. "Four Profiles in Courage,” Louisville Courier-Journal, Jan. 29, 2015. . Unconditional Unionist: The Hazardous Life of Lucian Anderson,

Kentucky

Congressman. Jefferson: McFarland \& Company Publishers, 2016.

Crofts, Daniel W. Reluctant Confederates: Upper South Unionists in the Secession Crisis.

Chapel Hill: The University of North Carolina Press, 1989.

Current, Richard Nelson. Lincoln's Loyalists: Union Soldiers from the Confederacy. New York:

Oxford University Press, 1992.

Daniel, Larry J. Days of Glory: The Army of the Cumberland, 1861-1865. Baton Rouge: Louisiana State University Press, 2004. 
Army of Battle of Stones River: The Forgotten Conflict Between the Confederate

Tennessee and the Union Army of the Cumberland. Baton Rouge: Louisiana State University Press, 2012.

Davis, Michael. The Image of Lincoln in the South. Knoxville: The University of Tennessee Press, 1971.

De Falaise, Louis. "General Stephen Gano Burbridge's Command in Kentucky," The Register of the Kentucky Historical Society, Vol. 69, No. 2. April 1971.

Dollar Kent T. and Whiteaker Larry H., ed. Sister States, Enemy States: The Civil War in Kentucky and Tennessee. Lexington: University Press of Kentucky, 2009.

Donald, David Herbert. Lincoln. New York: Simon and Schuster, 1995. .ed. Why the North Won the Civil War: Six Authoritative Views on the Economic, Military, Diplomatic, Social, and Political Reasons Behind the Confederate Defeat. New York; Simon and Schuster, 1960.

Durbin, Michael J. United States Gubernatorial Elections, 1861-1911. Jefferson: McFarland \& Company Publishers, 2010

Eisenhower, John S. D. American General: The Life and Times of William T. Sherman. New

York: Dutton Caliber Publishing, 2015.

Engle, Stephen D. "Don Carlos Buell: Misunderstood Commander of the West" in Kent T.

Dollar, Larry H. Whiteaker, and W. Calvin Dickinson ed. Border Wars: The Civil War in Tennessee and Kentucky. Kent: Kent State University Press, 2015.

Egerton Douglas R. Year of Meteors: Stephen Douglas, Abraham Lincoln, and the Election that Brought on the Civil War. New York: Bloomsbury Press, 2012.

Fackler, Stephen W. "John Rowan and the Demise of Jeffersonian Republicanism in Kentucky, 1819-1831," The Register of the Kentucky Historical Society Volume 78. 1980.

Faust, Drew G. This Republic of Suffering: Death and the American Civil War. New York:

Knopf Books, 2008. 
Foner, Eric. Free Soil Free Labor Free Men: The Ideology of the Republican Party Before the

Civil War. New York: Oxford University Press, 1970.

W.W. The Fiery Trial: Abraham Lincoln and American Slavery. New York:

Norton and Company, 2010.

Freeman, Douglas S. R.E. Lee: A Biography. New York: Scribner \& Sons, 1936.

Freehling, William W. The South vs. The South: How Anti-Confederate Southerners Shaped the

Course of the Civil War. New York: Oxford University Press, 2001.

Gannon, Barbara A. The Won Cause: Black and White Comradeship in the Grand Army of the

Republic. Chapel Hill: University of North Carolina Press, 2011.

Goff, John S. “Colonel James P. Carter of Carter County.” Tennessee Historical Quarterly. Vol.

26, No. 4. Winter 1967.

Goodwin, Doris Kearns. A Team of Rivals: The Political Genius of Abraham Lincoln. New

York: Simon and Schuster, 2005.

Guelzo, Allen C. Abraham Lincoln: Redeemer President. Grand Rapids: Eerdmans Publishing Company, 1999.

Fateful Lightning: A New History of the Civil War and Reconstruction.

New

York: Oxford University Press, 2012. . Gettysburg: The Last Invasion. New York: Vintage Books, 2013

Hafendorfer, Kenneth. The Battle of Wildcat Mountain. Louisville: KH Press, 2003.

Harris, William C. Lincoln and the Border States. Lawrence: University Press of Kansas, 2011.

Harrison, Lowell H. The Civil War in Kentucky. Lexington: The University Press of Kentucky, 1975. 

Lincoln of Kentucky. Lexington: The University Press of Kentucky, 2000.

Harrison, Lowell H. and Klotter, James C. A New History of Kentucky. Lexington: The University Press of Kentucky, 1997.

Harrold, Stanley. "Violence and Nonviolence in Kentucky Abolitionism," The Journal of Southern History, Vol. 57, No. 1. Feb., 1991.

Hess, Earl J. The Civil War in the West: Victory and Defeat from the Appalachians to the Mississippi. Chapel Hill: The University of North Carolina Press, 2012.

Holzer, Harold. Lincoln at Cooper Union: The Speech that Made Abraham Lincoln President

New York: Simon and Schuster, 2004.

Lincoln President-Elect: Abraham Lincoln and the Great Secession

Winter 1860-1861. New York: Simon and Schuster, 2008.

Holzer, Harold and Garfinkle, Nicholas. A Just and Generous Nation: Abraham Lincoln and the

Fight for American Opportunity. New York: Basic Books, 2015.

Hood, Larry J. "For the Union: Kentucky's Unconditional Unionist Congressmen and the Development of the Republican Party in Kentucky, 1863-1865," The Register of the Kentucky Historical Society, 76 (Summer 1978): 210

Howard, Victor. Black Liberation in Kentucky: Emancipation and Freedom, 1862-1884. Lexington: University Press of Kentucky, 1983.

Howe, Daniel Walker. The Political Culture of the American Whigs. Chicago: University of Chicago Press, 1979.

Kleber, John E. ed. The Kentucky Encyclopedia. Lexington: University Press of Kentucky, 1992.

Klotter, James C. "Kentucky, the Civil War, and the Spirit of Henry Clay." The Register of the

Kentucky Historical Society, Vol. 110, (Summer/Autumn 2012): 243-264.

University . Henry Clay: The Man Who Would Be President. Oxford: Oxford Press, 2018

Klotter, James C. and Klotter, Freda C. A Concise History of Kentucky. Lexington: University

Press of Kentucky, 2008. 
Lewis, Patrick. For Slavery and Union: Benjamin Buckner and Kentucky Loyalties in the Civil

War. Lexington: University Press of Kentucky, 2015.

Lincoln, Abraham, and Roy P. Basler. The Collected Works of Abraham Lincoln. New Brunswick, N.J.: Rutgers University Press, 1953.

Linderman, Gerald F. Embattled Courage: The Experience of Combat in the American Civil

War. New York: The Free Press, 1987.

Mackey, Thomas C. "Not a Pariah, but a Keystone: Kentucky and Secession," Sister States,

Enemy States: The Civil War in Kentucky and Tennessee, ed. Kent T. Dollar, Larry $\mathrm{H}$.

Whiteaker, and W. Calvin Dickinson, 25-47, Lexington: The University Press of Kentucky, 2009.

Maltz, Earl M. Dred Scott and the Politics of Slavery. Lawrence: University Press of Kansas, 2007.

Marshall, Anne E. Creating a Confederate Kentucky: The Lost Cause and Civil War Memory in a Border State. Chapel Hill: University of North Carolina Press, 2010.

Masur, Louis P. Lincoln's Hundred Days: The Emancipation Proclamation and the War for the

Union. Cambridge: Belknap Press of Harvard University Press, 2012.

McDonough, James L. Stones River: Bloody Winter in Tennessee. Knoxville: University of

Tennessee Press, 1983.

. War in Kentucky: From Shiloh to Perryville. Knoxville: The University of Tennessee Press, 1994.

W.W. . William Tecumseh Sherman: In the Service of My Country. New York: Norton, 2017.

McKnight, Brian. Contested Borderland: The Civil War in Appalachian Kentucky and Virginia.

Lexington: The University Press of Kentucky, 2006. 
. "Reconsidering Felix Zollicoffer: The Influence of Weather and Terrain

in the

Rise and Fall of a Military Commander in Appalachia." Border Wars: The Civil

War in Tennessee and Kentucky ed. Kent T. Dollar, Larry H. Whiteaker, and W.

Calvin Dickinson, 147-169, Kent: Kent State University Press, 2015.

McPherson, James M. Battle Cry of Freedom: The Civil War Era. New York: Oxford University

Press, 1988.

Oxford

. Drawn with the Sword: Reflections on the Civil War Era. New York:

University Press, 1996.

Oxford

For Cause and Comrade: Why Men Fought in the Civil War. New York:

University Press, 1998.

. Tried by War: Abraham Lincoln as Commander in Chief. New York: The Penguin Press, 2008.

Millard, Candice. Destiny of the Republic: A Tale of Madness, Medicine, and the Murder of $a$

President. New York: Anchor Books, 2012.

Miller, William Lee. Lincoln's Virtues: An Ethical Biography. New York: Alfred A. Knopf, 2002.

Myers, Raymond E. The Zollie Tree. Louisville: The Filson Club Press, 1964.

Neely Jr., Mark E. Lincoln and the Triumph of the Nation: Constitutional Conflict in the American Civil War. Chapel Hill: The University of North Carolina Press, 2010.

. The Fate of Liberty: Abraham Lincoln and Civil Liberties. New York:

Oxford

University Press, 1991.

America . The Last Best Hope of Earth: Abraham Lincoln and the Promise of

Cambridge: Harvard University Press, 1993.

Nevin, Allan. Ordeal of the Union, 8 volumes. New York: Scribner \& Sons, 1947-71.

Noe, Kenneth W. "Battle Against the Traitors: Unionist Middle Tennesseans in the Ninth 
Kentucky Infantry and What They Fought For.” Sister States, Enemy States: The Civil

War in Kentucky and Tennessee, ed. Kent T. Dollar, Larry H. Whiteaker, and W. Calvin Dickinson, 123-139, Lexington: University Press of Kentucky, 2009. Perryville: The Grand Havoc of Battle. Lexington: University Press of Kentucky, 2001.

. "Toward the Myth of Unionist Appalachia, 1865-1883," Journal of the Appalachian Studies Association 6 (1994): 73-80.

Noe, Kenneth and Wilson, Shannon eds. The Civil War in Appalachia: Collected Essays Knoxville: University of Tennessee Press, 1997.

Oates, Stephen B. To Purge This Land With Blood: A Biography of John Brown. Amherst: The

University of Massachusetts Press, 1970.

York: With Malice Toward None: A Biography of Abraham Lincoln. New

Harper and Row, 1977.

Phillips, Christopher The Civil War and the Border South: Reflections on the Civil War Era.

Santa Barbara: Praeger Publishing, 2013. . The Rivers Ran Backward: The Civil War and the Remaking of the American Middle Border. New York: Oxford University Press, 2016.

Quisenberry, A.C. “Kentucky’s 'Neutrality’ in 1861,” Register of Kentucky State Historical

Society, Vol. 15, No. 43, (Jan. 1917): 9-21.

Ramage, James A. and Watkins, Andrea S. Kentucky Rising: Democracy, Slavery, and Culture Kentucky, from the Early Republic to the Civil War. Lexington: The University Press of 2011.

Remini, Robert. Henry Clay: A Stateman for the Union. New York: WW Norton \& Co., 1991.

Richardson, H. Edward. Cassius Marcellus Clay: Firebrand of Freedom. Lexington: University

Press of Kentucky, 1976. 
Rhodes, James F. History of the Civil War: 1861-1865. New York: Reservoir House, 1917.

Rhyne, J. Michael. “A Blood Stained Sin: Slavery, Freedom, and Guerilla Warfare in the Bluegrass Region of Kentucky, 1863-1865," The Register of the Kentucky

Historical Society, Vol. 112, No. 4, Autumn 2014.

Sanders, Stuart W. The Battle of Mill Springs. Charleston: The History Press, 2013.

Sears, Richard. Camp Nelson, Kentucky: A Civil War History. Lexington: University Press of Kentucky, 2002.

Register of . “John G. Fee, Camp Nelson, and Kentucky Blacks, 1864-1865," The the Kentucky Historical Society, Vol. 85, No. 1. Winter 1987.

Speed, Thomas. The Union Cause in Kentucky: 1860-1865. New York: The Knickerbocker Press, 1907.

Toomey, Michael. "There Is Shameful Wrong Somewhere: The 1861 Campaign to Liberate East

Tennessee," in Kent T. Dollar, Larry H. Whiteaker, and W. Calvin Dickinson ed. Border Wars: The Civil War in Tennessee and Kentucky. Kent: Kent State University Press, 2015.

Waite, Cally L. "The Segregation of Black Students at Oberlin College after Reconstruction,"

History of Education Quarterly, Vol. 41, No.3. (Autumn), 2001.

Williams, Kenneth H. and Harris, James Russell. "Kentucky in 1860: A Statistical Overview."

The Register of the Kentucky Historical Society, Vol. 103, No. 4 (Autumn 2005):743-764.

Woodworth, Steven E. “The Indeterminate Quantities: Jefferson Davis, Leonidas Polk, and the

End of Kentucky Neutrality, September 1861." Civil War History, Vol. 38, No. 4, Dec. 1992 (Kent State University Press): 289-297.

Wright, Stephen L. ed. Kentucky Soldiers and Their Regiments in the Civil War: Abstracted McDowell

From the Pages of Contemporary Kentucky Newspapers. Vol. 1. 1861. Utica:

Publications, 2009. 
Wright, T.J., History of the Eighth Regiment of Kentucky Voluntary Infantry During its Three

Years Campaign. St. Joseph, MO: St. Joseph Steam Printing Company, 1880.

\section{THESES AND DISSERTAIONS}

Goebel, Robert William. "Casualty of War: The Governorship of Beriah Magoffin, 18591862." (2005). Electronic Theses and Dissertations at the University of Louisville. Paper 506.

Lee, Jacob F. "The Union as It Was and the Constitution as It Is: Unionism and Emancipation in Civil War Era Kentucky." (2007). Electronic Theses and Dissertations at the University of Louisville. Paper 807.

Parmley, Curtis Lushawn. "The Greatest Evil that Can Befall Us: Unionism in Antebellum Era Kentucky, 1849-1861." (2012). Electronic Theses and Dissertations at the University of Louisville. Paper 1096.

\section{PRIMARY SOURCES}

1890 Special Veterans Census for Eastern Kentucky. Ed. Charles C. Wells. Baltimore: Gateway Press, 2000.

A Union Woman in Civil War Kentucky: The Diary of Frances Peters, ed. John David Smith and William Cooper Jr. Lexington: The University Press of Kentucky, 2000.

Drafts in Kentucky During Civil War, A Letter from the Secretary of War, In Response to Senate Resolution Number 63, by Mr. Bradley, of July 2, 1909, A Letter from the Adjutant-General of the Army Setting Forth Such Information as it is Possible to Furnish Concerning the Drafts in the State of Kentucky during the Civil War. Document 142, $61^{\mathrm{st}}$ Congress, $1^{\text {st }}$ Session (Congressional Record), 1909, 14 Pages.

Kentucky Department for Libraries and Archives, Frankfort, KY. The Civil War Governors of Kentucky. Digital Documentary Edition.

Kentucky. General Assembly. House of Representatives., "Journal of the House of Representatives of the Commonwealth of Kentucky, September 2, 1861 - March 3, 1863, Volume One" (1861). Journals of the General Assembly of the Commonwealth of Kentucky.

Report on the History of Jackson County to 1918 by Isaac Anderson Bowles. retyped and mimeographed by the Public Relation and Power Use Department of Jackson County R.E.C.C. in McKee KY, 1977. 
The Annotated Memoirs of Ulysses S. Grant ed. Elizabeth D. Samet. New York:

Liveright of

W.W. \& Norton Publishing, 2018.

The Collected Works of Abraham Lincoln. New Brunswick: Rutgers University Press, 1959. 8 Volumes.

The War of the Rebellion: A Compilation of the Official Records of the Union and

Confederate Armies. Washington D.C.: Government Printing Office, 1880-1901. 128

Volumes.

\section{NEWSPAPERS AND OTHER SOURCES}

The Berea Citizen.

The Lexington National Unionist.

The Louisville Daily Journal

Kentucky Soldiers and Their Regiments in the Civil War: Abstracted from the Pages of Contemporary Kentucky Newspapers. Vol. 1. (1861) edited by Stephen L. Wright. Utica: McDowell Publications, 2009.

A Portrait of Jackson County: 1858-2008. Virginia Beach: Donning Company Publishers, 2008.

Presidential Elections, 1789-2008: County, State, and National Mapping of Election Data ed. Donald R. Deskin, Hanes Walton, and Sherman C. Puckett. Ann Arbor: The University of Michigan Press, 2010. 


\section{CURRICULUM VITAE}

Name: Howard Lucas Muncy

Email: howardlmuncy@gmail.com

\section{EDUCATION ANDSCHOLARSHIP}

MASTER OF ARTS IN HISTORY | UNIVERSITY OF LOUISVILLE \& GEORGETOWN UNIVERSITY | Louisville, Kentucky and Washington, D.C. | Grad. 2019

- Graduate Fellow, James Madison Memorial Scholarship, 2016-present

- Thesis topic:

- "A Forgotten Shade of Blue: Support For the Union and a Constitutional Republic in Southeastern Kentucky During the Civil War Era"

- Thesis Advisor:

- Thomas C. Mackey (Ph.D., United States Legal and Constitutional History, Rice University), Emeritus Professor of History, University of Louisville

- Coursework included: HIST 605 Research Methods, HIST 601 Constitutional Problems in the Civil War Era, HIST 662 The Renaissance, HIST 611 The Era of Lincoln, HIST 611 The History of American Childhood, LSHS 520 Foundations of the American Constitution (6 Credit Hours Awarded at Georgetown University)

SEMINAR SCHOLAR | GILDER LEHRMAN INSTITUTE OF AMERICAN HISTORY | OXFORD UNIVERSITY | ST. CATHERINE'S COLLEGE | Oxfordshire, England $\mid 2015$

- Richard Carwardine, (D.Phil., History, Oxford University), Rhodes Professor of American History, Oxford University

- Seminar: The Era of Lincoln

TEACHER-SCHOLAR | HISTORY, POLITICS, AND SOCIETY | OXFORD UNIVERSITY | EXETER COLLEGE | Oxfordshire, England | 2012

- Awarded full-tuition scholarship through the English-Speaking Union

- Research papers included: "A Cold War Misstep: The Geopolitical Impact of Introducing American Forces in Lebanon in 1982," and "WWI: Launching Labour Forward."

- Advisors included: Tom Buchanan (D.Phil., History, Oxford University), Director of Studies in History and Politics, Oxford University; and, Farhang Jahanpour (Ph.D., Oriental Studies, University of Cambridge), Tutor, Department of Continuing Education, Oxford University

- Coursework included: British Politics 1900 - 1945; Contemporary Middle East 
MASTER OF ARTS IN TEACHING | EASTERN KENTUCKY UNIVERSITY

Richmond, Kentucky $\mid 2003$

- Research thesis "An Interdisciplinary Approach to the History Classroom."

- Student-teaching placement at North Laurel High School.

- Graduate history courses included HIS 806 Early Middle Ages, HIS 807 Problems in Interpreting American History, HIS 716 Kentucky History, POL 893 Foundations of Civic Education

\section{BACHELOR OF ARTS IN HISTORY | EASTERN KENTUCKY UNIVERSITY} Richmond, Kentucky $\mid 2002$

- HIS 300 History of the Vietnam War, HIS 339 Medieval History, HIS 300 SubSahara Africa, HIS 345 English History to 1603, HIS 413 US and World Responsibility 1949-Present, HIS 433 American Diplomatic History, POL 405 Terrorism and International Policies

- The two required term papers for the program included research on John F. Kennedy \& Vietnam, and Franklin D. Roosevelt at Yalta

- The required senior research paper explored Secretary of Labor Frances Perkins

PROFESSIONAL EXPERIENCE HISTORY TEACHER | JACKSON COUNTY HIGH SCHOOL McKee, Kentucky| $2014-2020$

ADJUNCT PROFESSOR OF HISTORY FOR DUAL-CREDIT | EASTERN
KENTUCKY UNIVERSITY Richmond, Kentucky | 2017- 2020

SOCIAL STUDIES TEACHER | LEHIGH VALLEY CHARTER SCHOOL FOR THE ARTS | Bethlehem, Pennsylvania | 2018-2019

INSTRUCTOR | LAUREL COUNTY ADULT EDUCATION: LAUREL COUNTY LITERACY COUNCIL, INC.

London, Kentucky | $2007-2013$

STANDARDS AUTHOR | KENTUCKY DEPARTMENT OF EDUCATION Frankfort, Kentucky | Summer 2013

HISTORY TEACHER | NORTH LAUREL HIGH SCHOOL London, Kentucky | $2003-2014$

\section{CER T I F I CA T I ON S}

PROFESSIONAL CERTIFICATE FOR TEACHING SOCIAL STUDIES, GRADES 8-12

Issued by: Education Professional Standards Board, Commonwealth of Kentucky 
Effective: August 19, 2003| Expiration: June 30, 2023, Rank I Status Awarded August 2019

\section{PROFESSIONAL CERTIFICATE FOR TEACHING SOCIAL STUDIES,} GRADES 7-12

Teacher Information Management System, Commonwealth of Pennsylvania

Effective: September 1, 2018| Expiration: September 1, 2024

\section{PUBLICATIONS AND PRESENTATIONS}

- "Subjects Matter: It is Past Time to Rescue History from Its Present Decline" Published Article for The Witherspoon Institute's Online Journal Public Discourse, 2020.

- "The Book History Teachers Have Been Looking For: Wilfred McClay's Land of Hope" - Published Article for The Witherspoon Institute's Online Journal Public Discourse, 2019.

- "The Thirtieth Anniversary of Battle Cry of Freedom: An Interview with Dr. James McPherson" - Published Article for The Witherspoon Institute's Online Journal Public Discourse, 2019. Featured in The Wall Street Journal's "Notable and quotable."

- "Henry Clay and Abraham Lincoln: An Indirect Partnership." Presentation at annual conference of the Kentucky Council of Social Studies, October 2016.

- "Teaching Abraham Lincoln in the Classroom." Presentation at annual conference of the Kentucky Council of Social Studies, September 2015.

- "An Innovative Approach to Teaching Content and Reading in the History Classroom: Presidential Inaugural Addresses and Political Cartoons."Presentation at Kentucky Education Development Cooperative for (TAH) Teaching American History, June 2015.

- Muncy, Howard. “American Meritocracy: Clay and Lincoln's $19^{\text {th }}$ Century Political Construct.” Southern Social Studies Journal, Vol. 41, No. 2, (2015): 2328.

- Muncy, Howard. “Kentucky's Confederate Moss." National Endowment of the Humanities, July $25^{\text {th }}, 2013$ http://history.ky.gov/landmark/kentuckysconfederate-moss- $2 /$

\section{PROFESSIONAL MEMBERSHIPS}

- President, Kentucky Association for Teachers of History, 2017-2018

- Kentucky Colonel, Commissioned by Governor Steve Beshear, 2013

- Steering Committee, Kentucky Council for Social Studies, 2014-16 


\section{PROFESSIONAL CONFERENCES}

- “Executive Power," Keystone, SD, 2018

- "Adam Smith: Ethics and Economics," Louisville, KY, 2018

- "Henry Clay and the American System," Lexington, KY, 2017

- "Disruptive Innovation: Economics in the Classroom," Utah State University, Logan, UT, 2017

- "Comparative Constitutional Law: Fourth Annual Roundtable," Montpelier, VA, 2016

- "We the People Institute," University of Indiana, Bloomington, IN, 2016

- "Franklin's Political Thought, Liberty, and the American Revolution," Philadelphia, PA, 2016

- "The Sacred Rights of Conscience: Religious Liberty in America," Boston, MA, 2016

- Scholar, James Madison Legacy Project, 2015-2016

- "Twentieth Century Dystopian Literature," Louisville, KY, 2015

- "Alexis de Tocqueville's Democracy in America," Detroit, MI, 2014

- Teacher-Scholar, McConnell Center, University of Louisville, 2013-14, 2015-16

- "Liberty and the Western Tradition," Princeton University, Princeton, NJ, 2013

- "Kentucky and the Civil War," National Endowment for the Humanities, Frankfort, KY, 2013

- "Liberty and the Cold War," University of Kansas, Lawrence, KS, 2013

- "Economics from Smith to Friedman," Chicago, IL, 2011

- "Camelot at 50: The Kennedy Presidency," University of Virginia, Charlottesville, VA, 2011 